DEVONIA ROSSILS: CORA LS. 

With Compliments of

Games bal,

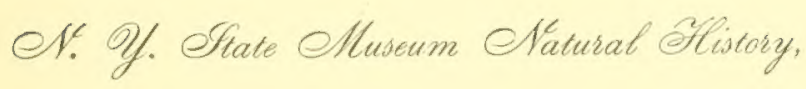

etlamy, et: Of. OH. eP. et. 



778

H2z

INVZ

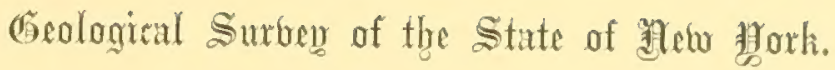

PALAON'TOLOGX.

\section{ILLUSTRATIONS}

OF

\section{DEVONIAN FOSSILS: CORALS \\ OF THE}

UPPER HELDERBERG AND HAMILTON GROUPS.

BY J A MES H A LL.

Puiblished in advance of the Palaeontology of New York, BY AUTHORITY OF

THE LEGISLATURE OF THE STATE OF NEW YORK

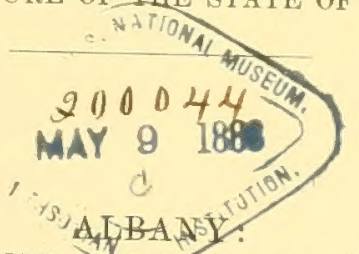

WEED, PARSONS AND OOMPANY, PRINTERS. 1876. 



\section{NOTE.}

In December, 1876, a volume of Albertype Illustrations of Devonian Fossils of the classes Gasteropoda, Pteropoda, Cephalopoda, Crusta. CEA and Corals was published in an edition of one hundred copies, by order of the Legislature. These copies were principally distributed to public institutions under the direction of the Secretary of State.

The Corats being less known than the other groups, and the preparation of a volume upon this class of Fossils, and of the Bryozoa of the lower and upper Helderberg, Hamilton and Chemung groups being now in progress, the author has had a few copies of the plates of Corals printed at his personal expense, with a view to their circulation among those who may be interested in the subject.

In the preparation of the volume referred to there have been already made more than 600 original drawings of Corals, and 300 of Bryozoans, which will soon be placed in the hands of the lithographer.

In this condition of progress the author would beg leave to solicit from scientific gentlemen and collectors of fossils, information concerning localities and the distribution of species, and also the contribution or loan of specimens which may aid in the completion of the work and become the means of disseminating a knowledge of this class of fossils, which are so widely and abundantly distributed throughout the Palæozoic formations of the United States. 

PHASES AND EXPLANATIONS

OF

CORALS.

PLATE I.

(Fur reference to the species, see Explanation of Plate 8.)

FAVOSITES TUBERose var.

The figure represents the lower side of a convex, sub-hemispheric specimen from which the epitheca has been removed by weathering, revealing the cells with the mural pores. The peculiar feature of the partial diaphragms which are represented in spiniform processes, has been to a great extent destroyed, but is seen in some places, and especially on the left of the figure. Upper Hellemberg Limestone, Cayuga, Ontario. 


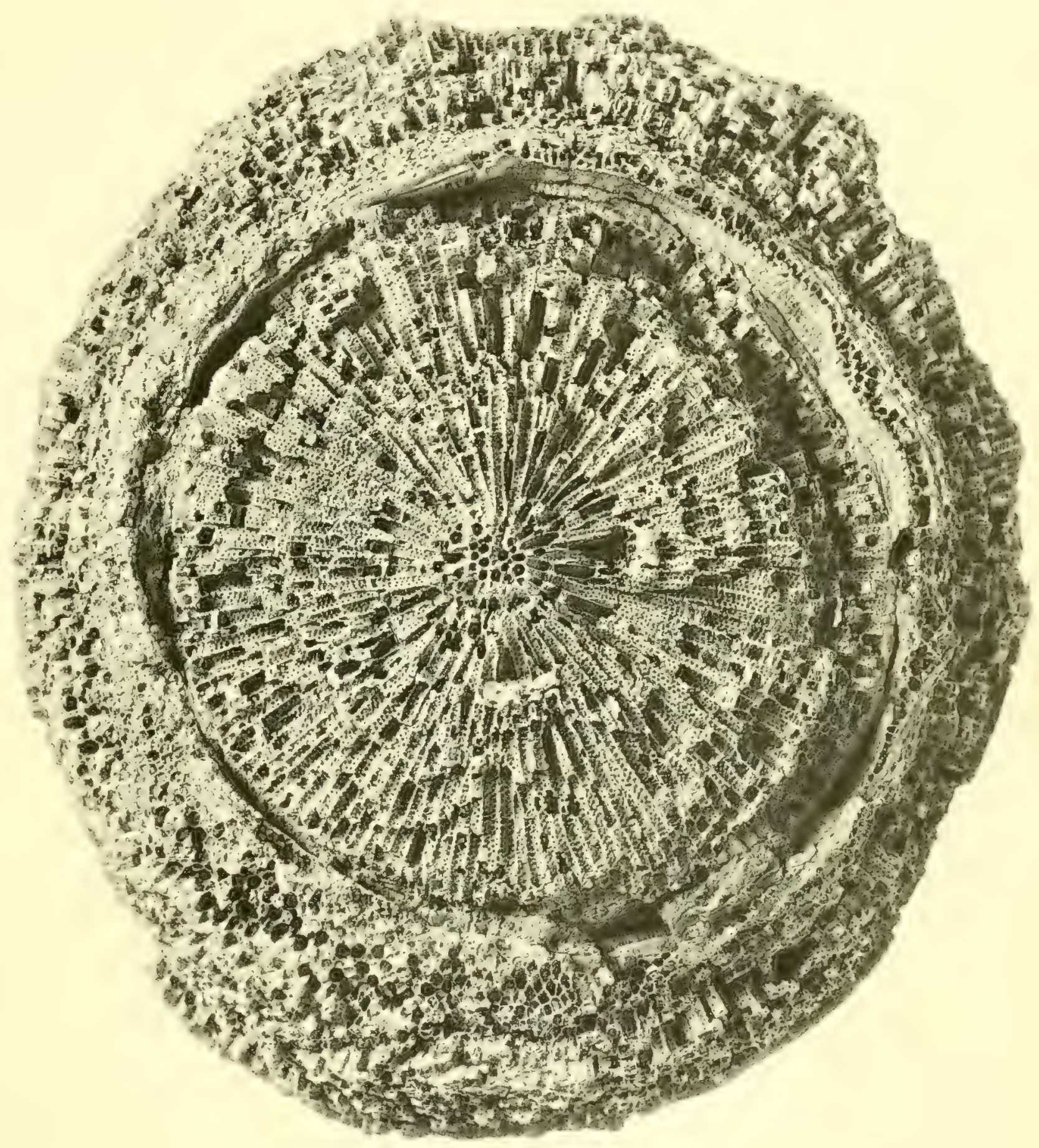


. 


\section{I'LATL; II.}

\section{FAVOSITES HEMISPHERICA.}

Cyathophyllum quadrigeminum (Guldf.) Eaton. Geological Text book, p. 38, pl. 5, f. 66. 183 .). Calamopora hemispherica Troost. Ann. Report Geol. Tennessee, p. 72. 1810.

Favosites hemispherica Fandell-Shumard. Contrib. to the Geology of Kentucky, p. $\%$. 1817.

" turbinata Billings. Canad. Journ., New Series, Vol. IV. p. 109. 1859.

$" 6$ ".

Not " hemispherica Billings. " " " " Vol. IV, p. 105. 1859.

Not Emmonsia "h Edw.-Haine, Polyp. Foss. Tex. Palrezoiques, p. 23r̃. 1850.

Favosites turbinata (Bill.) Nicholson. Palreontology of Ontario, Vol. I, p. 49. 1874

Figs, 1-3. Upper, basal aud lateral views of a typical specimen of the species, from near Louisville, Ky. This and others of a similar cinaracter were communicated by Dr. L. P. Ian. dell, as examples of the form referred to, and originally described under the name Furosites hemisplerica as above cited.

Figs, 4. 5. Lateral and basal views of another specimen, on which the point of origin is less distinctly defined than in the preceding. Locality the same as specimen $1-3$ 


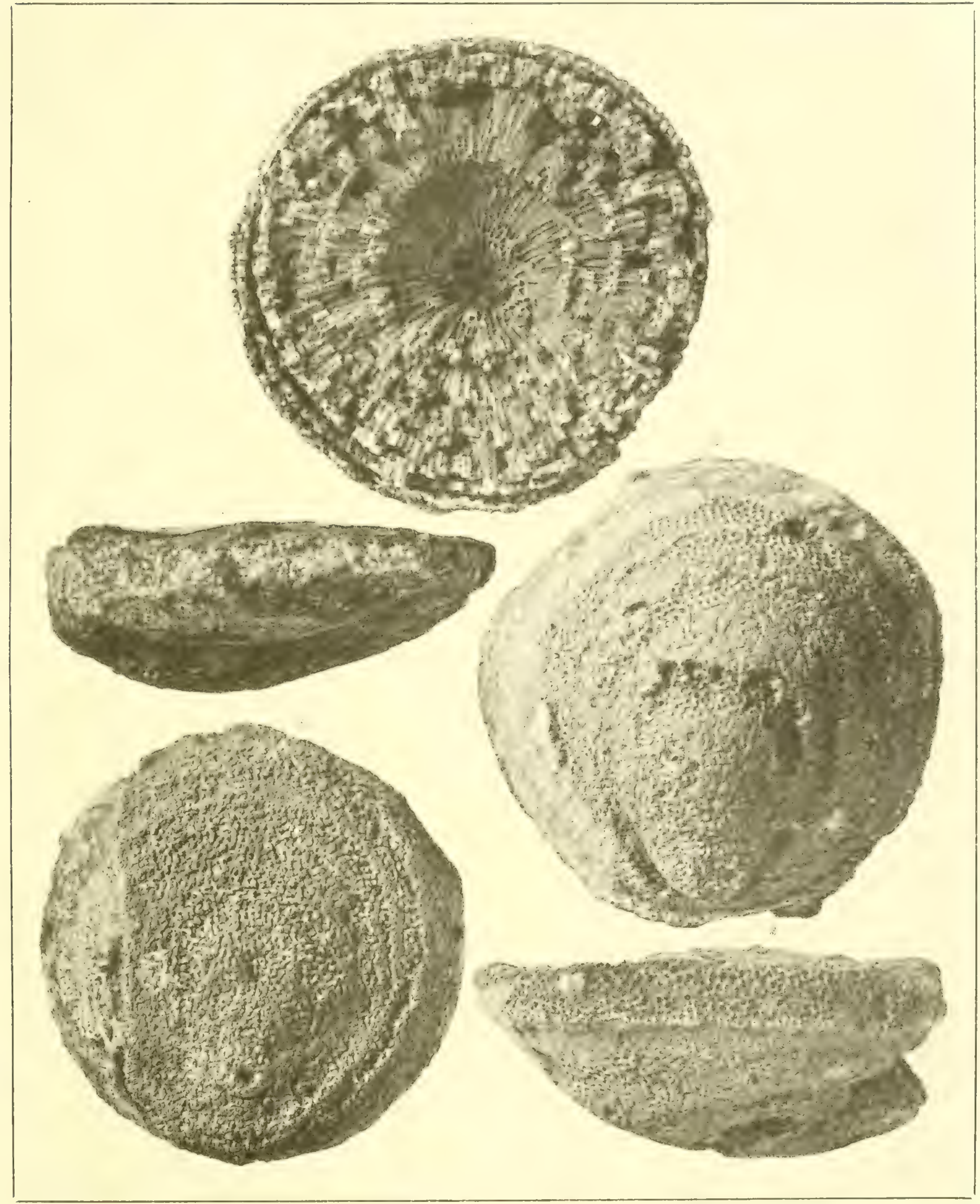




\section{PLATE II A.}

Favostes HeMispierica var. a. (subturbinate forms).

Figs. 1-3. Upper, lateral and basal views of a specimen of this variety, showing the small cells peculiar to this form.

Figs. 4, 5. Two views of another specimen of similar character, but having the upper part extended into a dome-shaped elevation.

Fig. 6. Lateral view of anotluer individual where the upper part is elevated into a conical form.

Fig. $\nmid$. Longitudinal section of a highly dome-shaned specimen, showing the diverging character of the cells in their upwarl extension. From the Upper Helderberg Limestore State of New York, and Iialls of the Olio. 


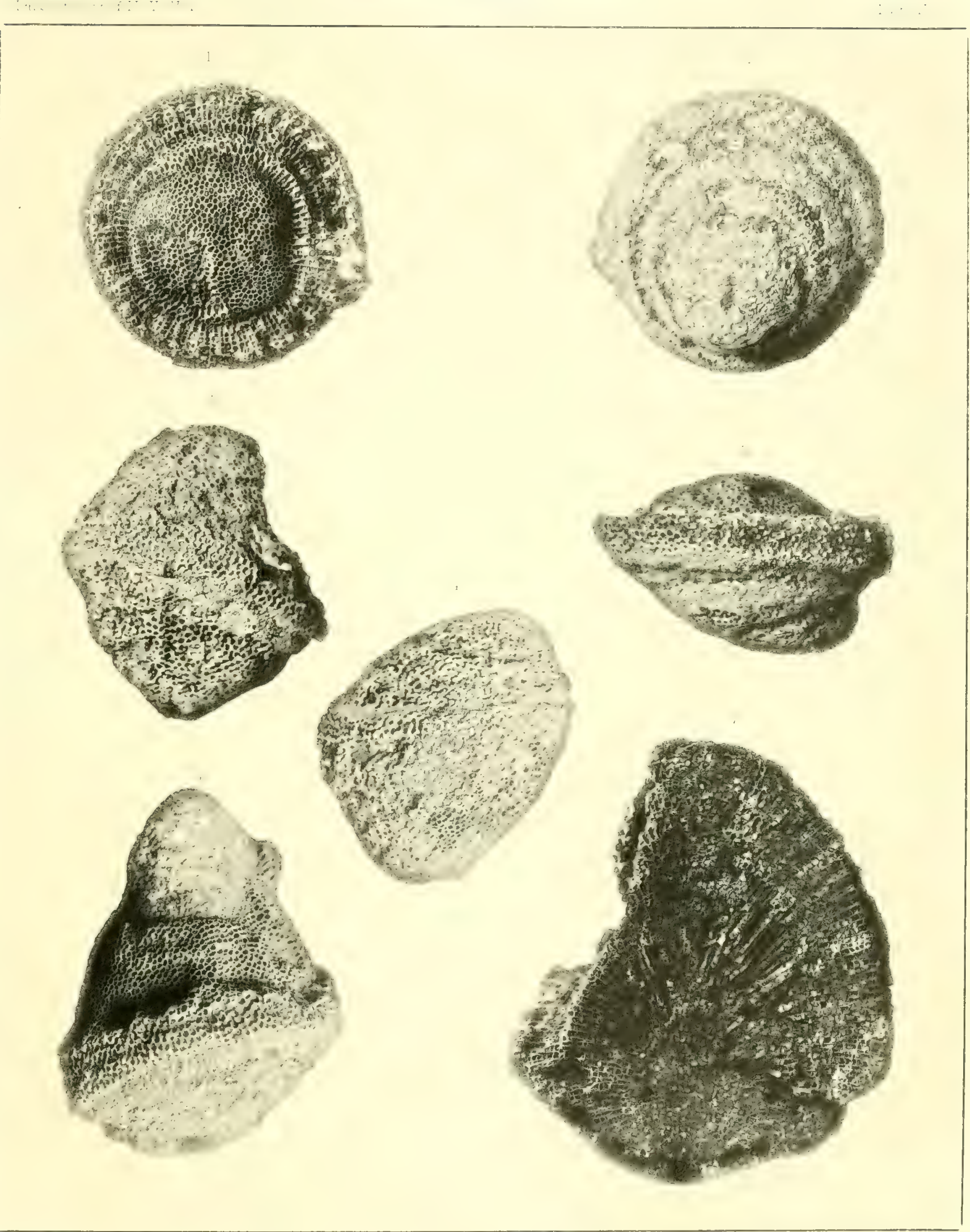





\section{PLATE II B.}

Fivosttes heMisphenica var. TURBinata.

Furosites turbinatu Billings. Canad. Jouru., New Series, IV, p. 109, 1859; V, p. 258, fig. \%, 1860.

Figs 1, 2. View of the lower side and lateral view of a turbinate specimen with a slender base, From the Upper Helderberg Limestone in Western New York, near Batavia.

Fig. 3. Lateral view of a more erect form, from Clarence Hollow, New York.

Vig. 4. Lateral view of a specimen which maintains its turbinate form to about lialf its height, and becomes clome-shnped above. The surface fitintly shows the structure. From the Upper Helderberg Limestone, Sandusky, Olio.

Fig. 5. Postero-lateral view of the same individual.

Fig. G. Section of a similar specimen showing, on the fractured surface, the faces of the tubes with the mural pores.

Fig. 7. A longitudinal section of a specimen showing the mode of growth of the cells, the transverse diaphragms and some of the mural pores.

Favosites hemispierica var.

Cyathophyllum quadrigeminum (Goldf.) Eaton. Geological Text book, p. 38, plate 5, fig. 66. 183:.

fig. 8. The base of a very robust specimen from the Upper Helderberg Limestone, Western New Fork. (See also plate 5). 


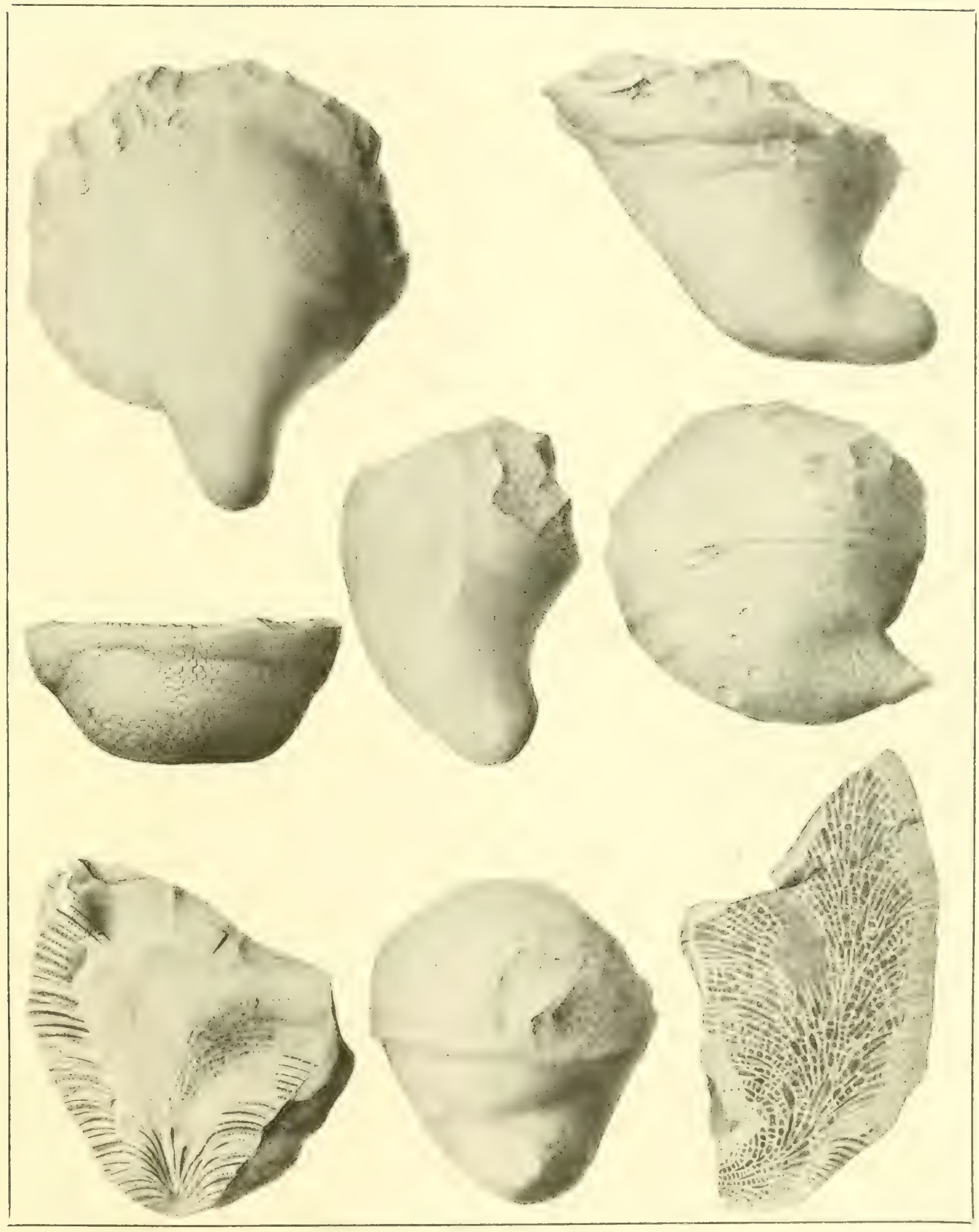




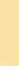





\section{PLATE II C.}

\section{FAYOSITES IIEMISPIIERICA var. RECTA.}

Figs. 1, 2. Views of the opposite sides (posterior and anterior) of a specimen of this variety, showing the erect form of the lower part, above which the coral expands more rapidly and irregularly.

Figs. 3, 4. Views of the opposite sides of another specimen, from the upper part of which project two buds or colunies, especially shown on the left side of figure 3. Upper Helderberg Limestone, Cayuga, Ontario.

\section{FAvosites meMispirerica var. TURBINATA.}

(For reference, sce Explanation of Plate 2 B.)

Fig. 5. View of the upper surface of a small weathered specimen, showing the form and size of the cells. From the Upper Helderberg Limestone, Falls of the Ohio. 

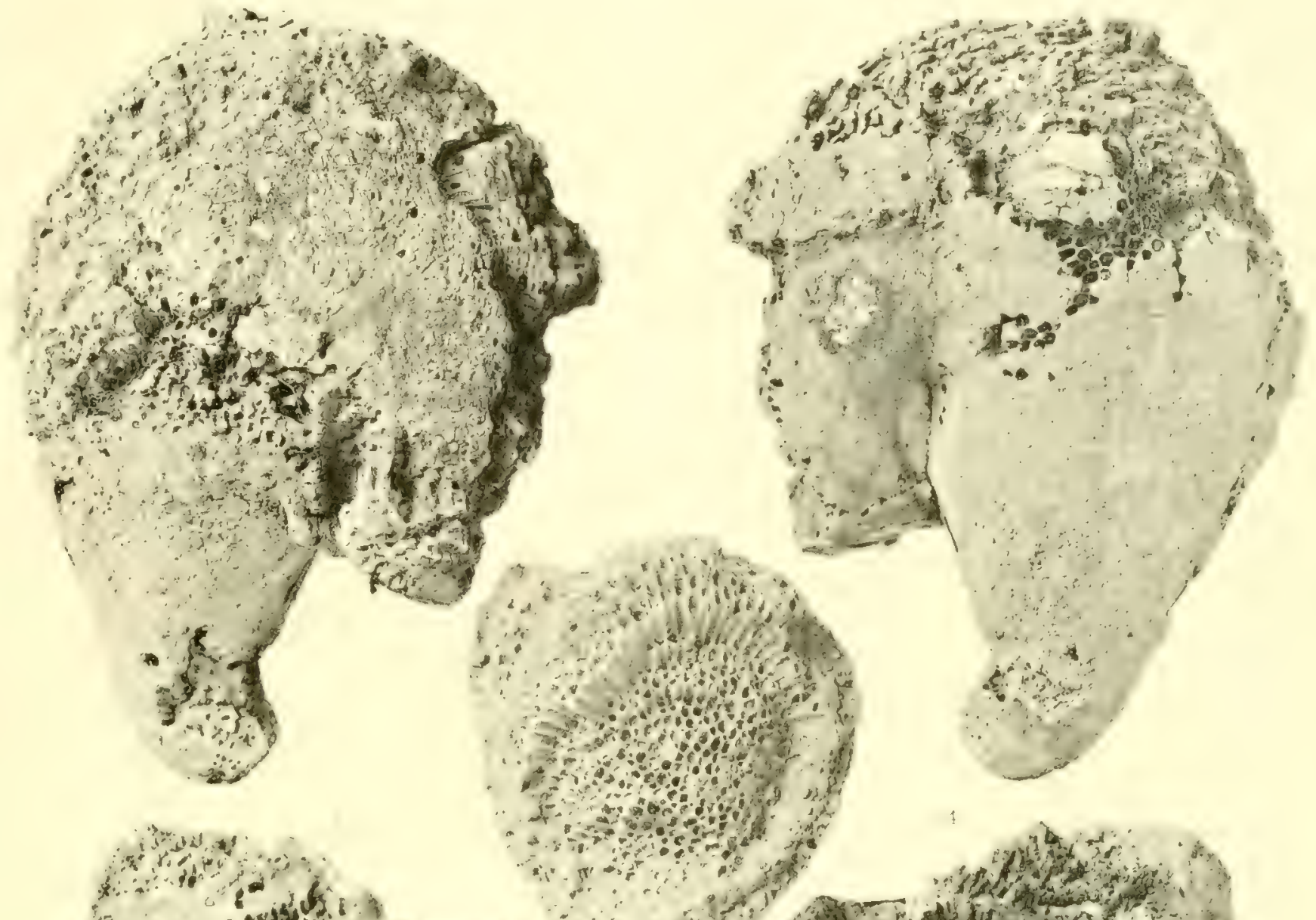

for

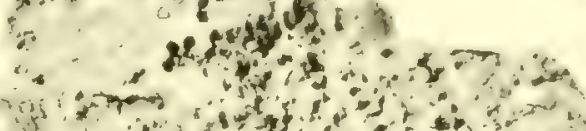

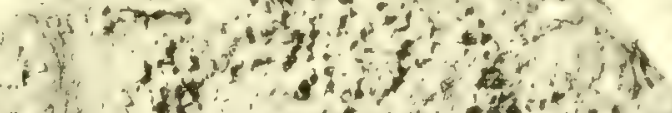

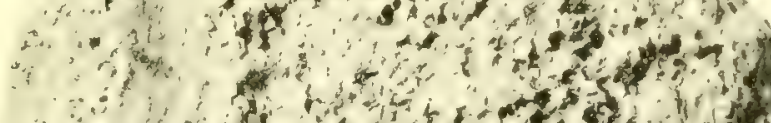

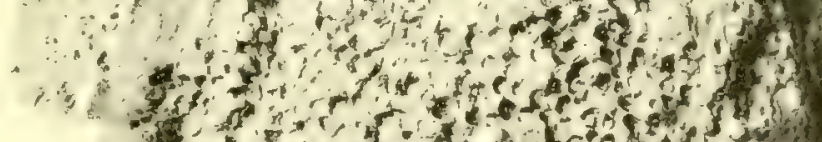

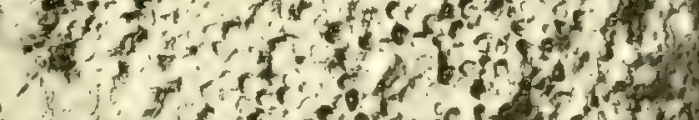

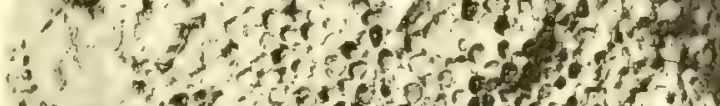

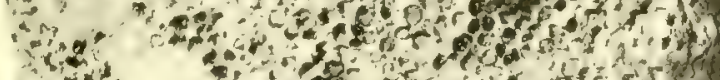

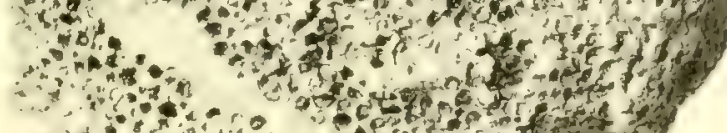

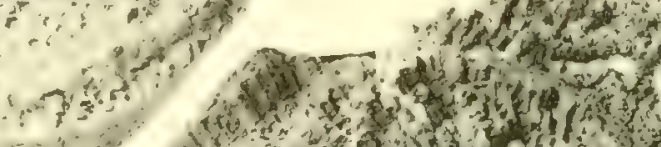

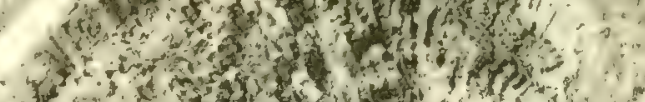
Das on

के $30.0 \%$

1.0.

r.

(.).

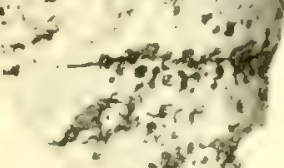

$$
\begin{aligned}
& \text { at }
\end{aligned}
$$

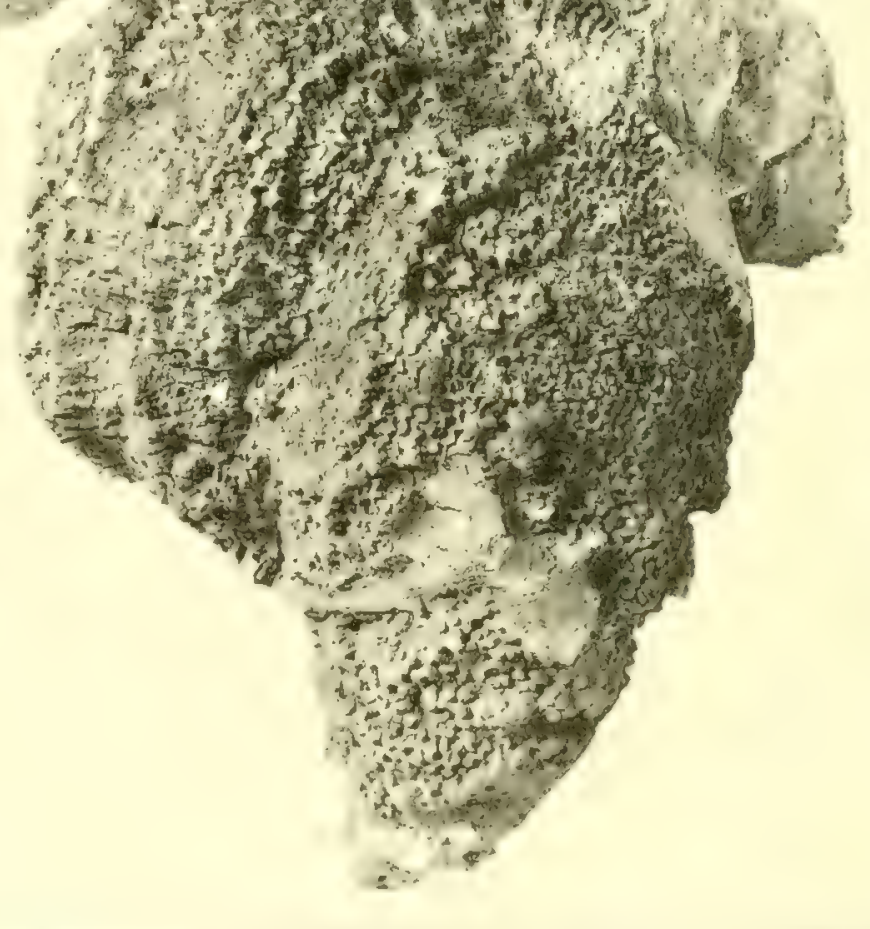



. 


\section{PLATE III.}

EATOSTTES HEMISPHERICA var.

Fig. 1. View of the side of a large, compressed turbinate specimen, from the surface of which the epitheca has been partially removed by weathering. From the Upper Helderberg Limestone, Cayuga, Ontario. 


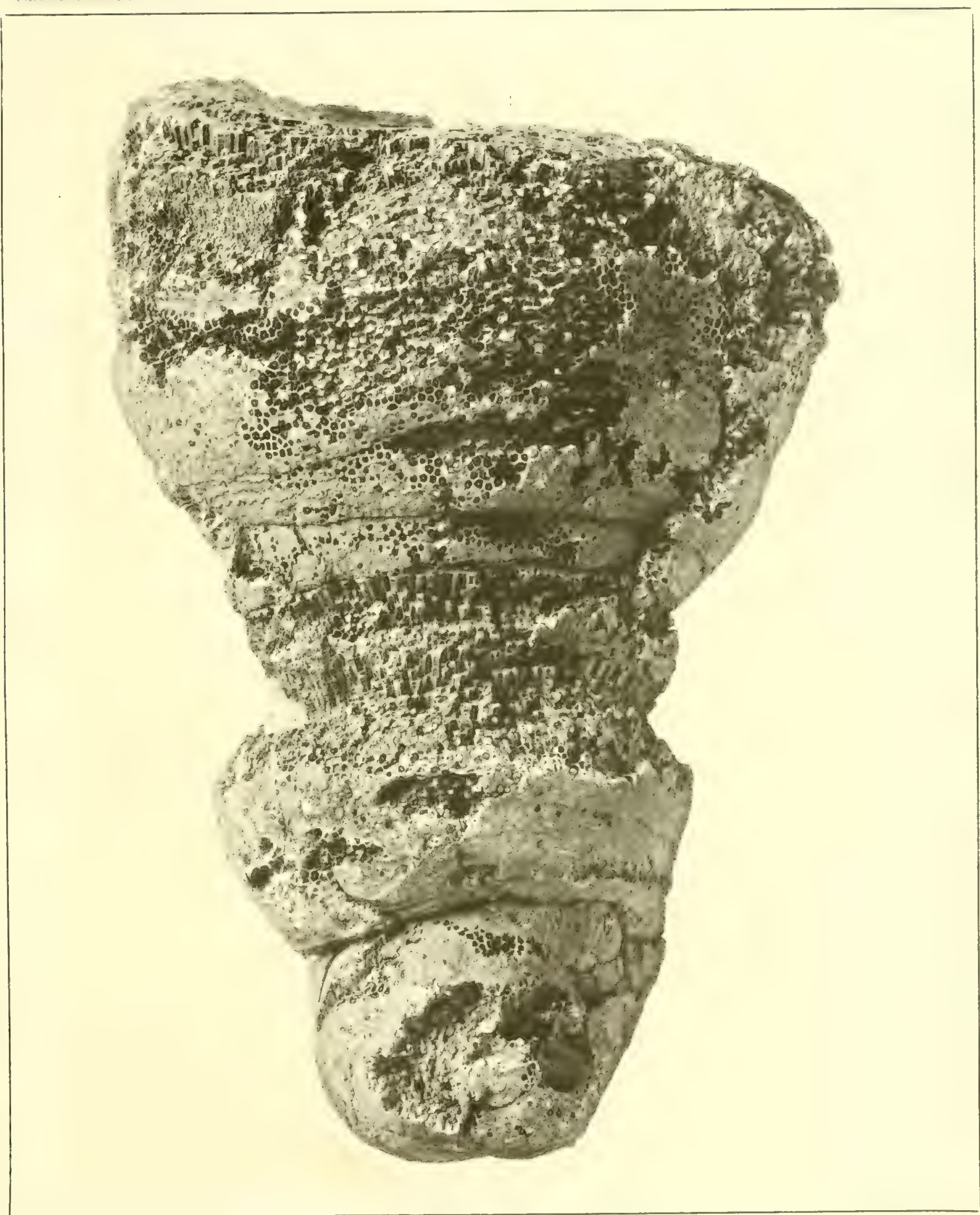





\section{PLATE IV.}

Favosites tuberosus var.

Furosites tuberosa Rominger, in part,

Fig. 1. View of a subclavate specimen, showing the form and size of the cells, and in some parts the complete tabulx. Upper Helderberg Limestone, Cayuga, Ontario.

EAVOSITHS HEMISPIERICA VMI. TURBINATA.

(See also Plrte : $B$.)

Fig. 2. Lateral view of a large, curved, subturbinate snecimen, covered by the epitheca which allows the cell-walls to be seen projecting through its substance. Upper Helderberg Limestone, Cayuga, Ontario. 


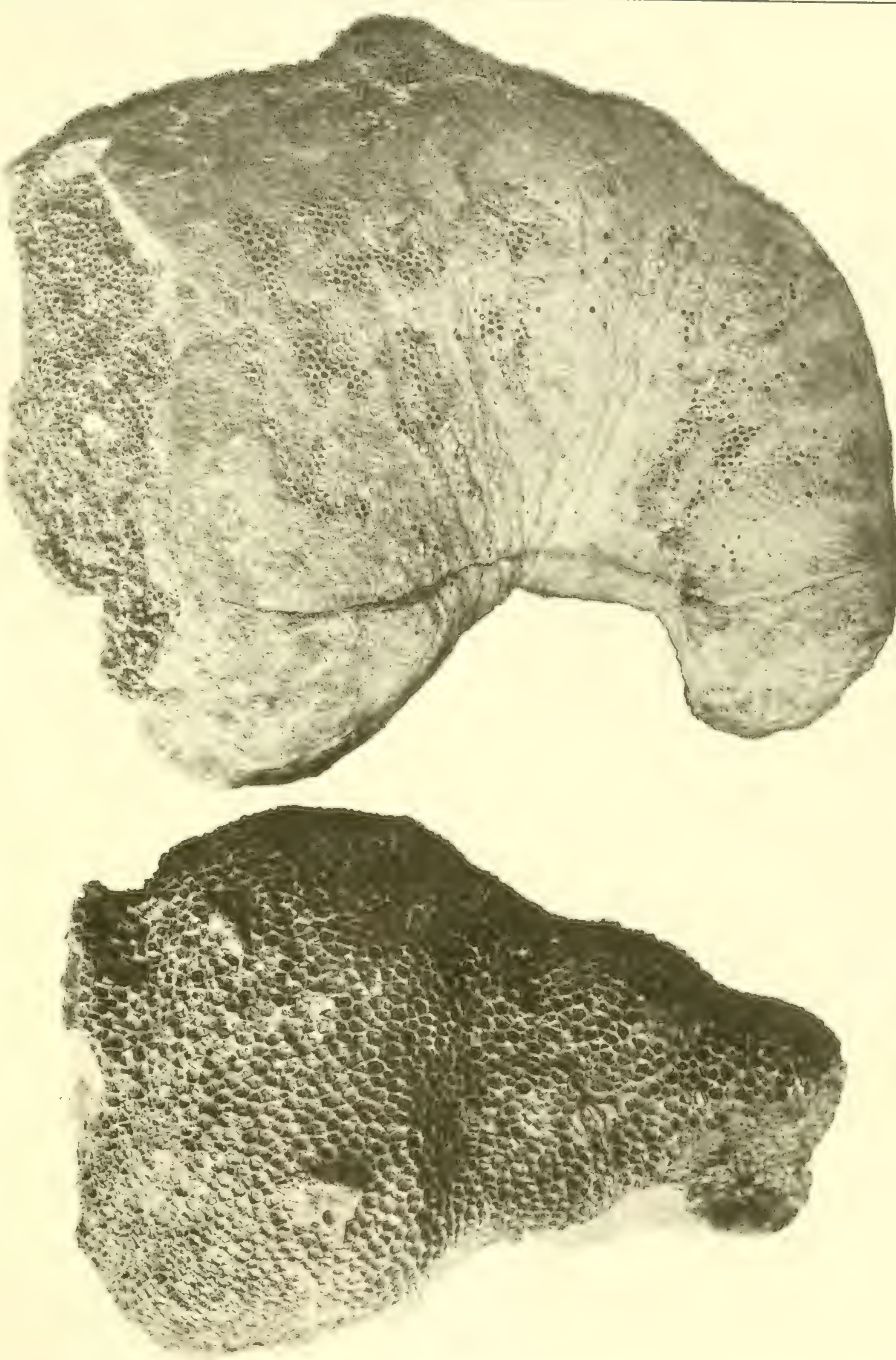






\section{PLA'TE V.}

\section{Fatosites InEMSPHERICA Vill: DISTOITA.}

Fig. 1. A large individual of this species, which has assumed a zigzag ditection in its progressive stages of growth.

Fig. 2. Another individual which has made a complete turn in an irregularly spiral direction.

Fi.. 3. A smaller specimen which has turned nearly at right angles in its progress of growth.

lig. 4. A smaller specimen which, in its progress of growth, has become turned almost birectangularly, the direction of the last stage of growth being precisely opposite to that of its commencement.

$\mathrm{F}$ g. 5. $\Lambda$ few of the cell-faces enlarged, showing the concentric growth of the operculiform epitheca. From the Limestone of the Upper Helderberg group in the Helderberg Mountains and at Schoharie.

This variety, and the cyathophylloid forms of the species were erroneously identified by Eaton with Cyathophyllum quadrigeminum of Goldluss, from the radiation of the cells as they cornmonly appear upon the iveathered surfaces. 


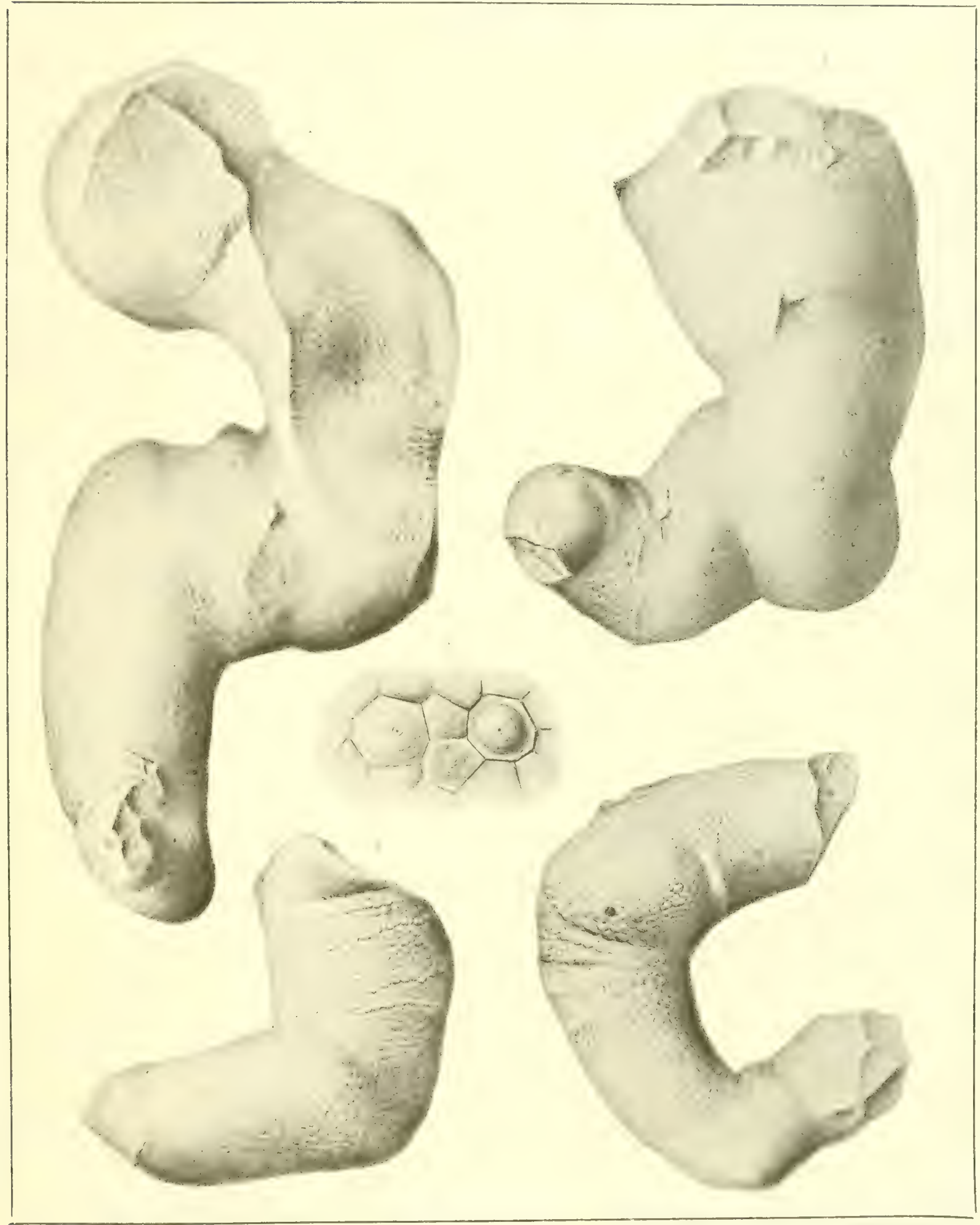

A B. Simpoon del, 




\section{PLATE VI.}

\section{Favosites emideritat.}

Euvosites epidermata Rominger. American Journal of Science, Vol. XXXIV, p. 396. 186?.

Figs. 1, 2. View of the opposite sides of a flatened clavate specimen, which is, to a great extent, destinte of epitheca, showing the form and size of the cells, and in many places, the remains of the partial transverse diaplarams.

Figs. 3, 4. Lateral and summit views of a smaller, somewhat similarly formed individual. This and the preceding specimen are from the Upper Helderberg limestone, near Akron, N. $Y$.

Fig. 5. View of a somewhat oblique longitudinal weathered scction, showing the size of the corallites with remains of the transverse diaphragins. Upper Helderberg group, near Caledonia, N. Y.

\section{FAYOSITES TUBEROSA.}

(See Plate 8.)

Fig. 6. A part of the onter surface of a large clavate form, showing the junction of the epithecal portion with the open cells. The epitheca is usually very thin, and leaves the projecting parts of the dead cells protruding, giving an exceedingly roughened surface. Upper Helderberg group, Cayuga, Ontario. 

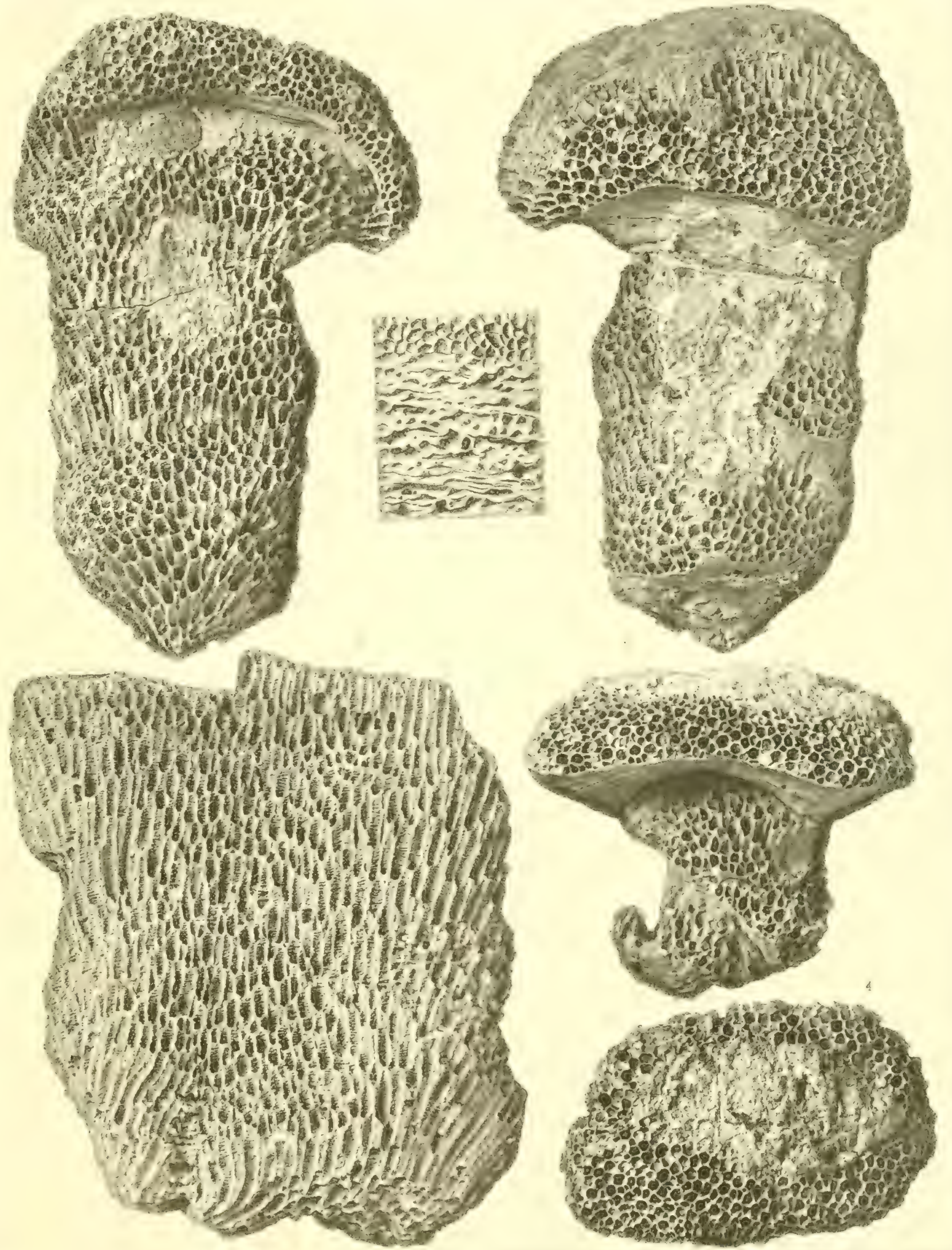



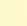




\section{PLATE VII.}

Fatosites tuberosi var.

Compare Favosites tuberosa Rominger.

Fig. 1. View of the upper surface of a large specimen, showing the form of the cells and the partial transrerse diaphragms. Upper Helderberg limestone, near Akron, N. Y.

\section{FAVOSITES EPIDERMATA? rar. BILOCULI.}

Occurring in spreading flattened masses.

Fig. 2. View of the upper surface of a large flat specimen, showing cells of two dimensions, the larger of which are mostly filled with quartz, and having resisted the weathering action, project above the smaller cells. Upper Helderberg group, Caledonia, N. Y. 

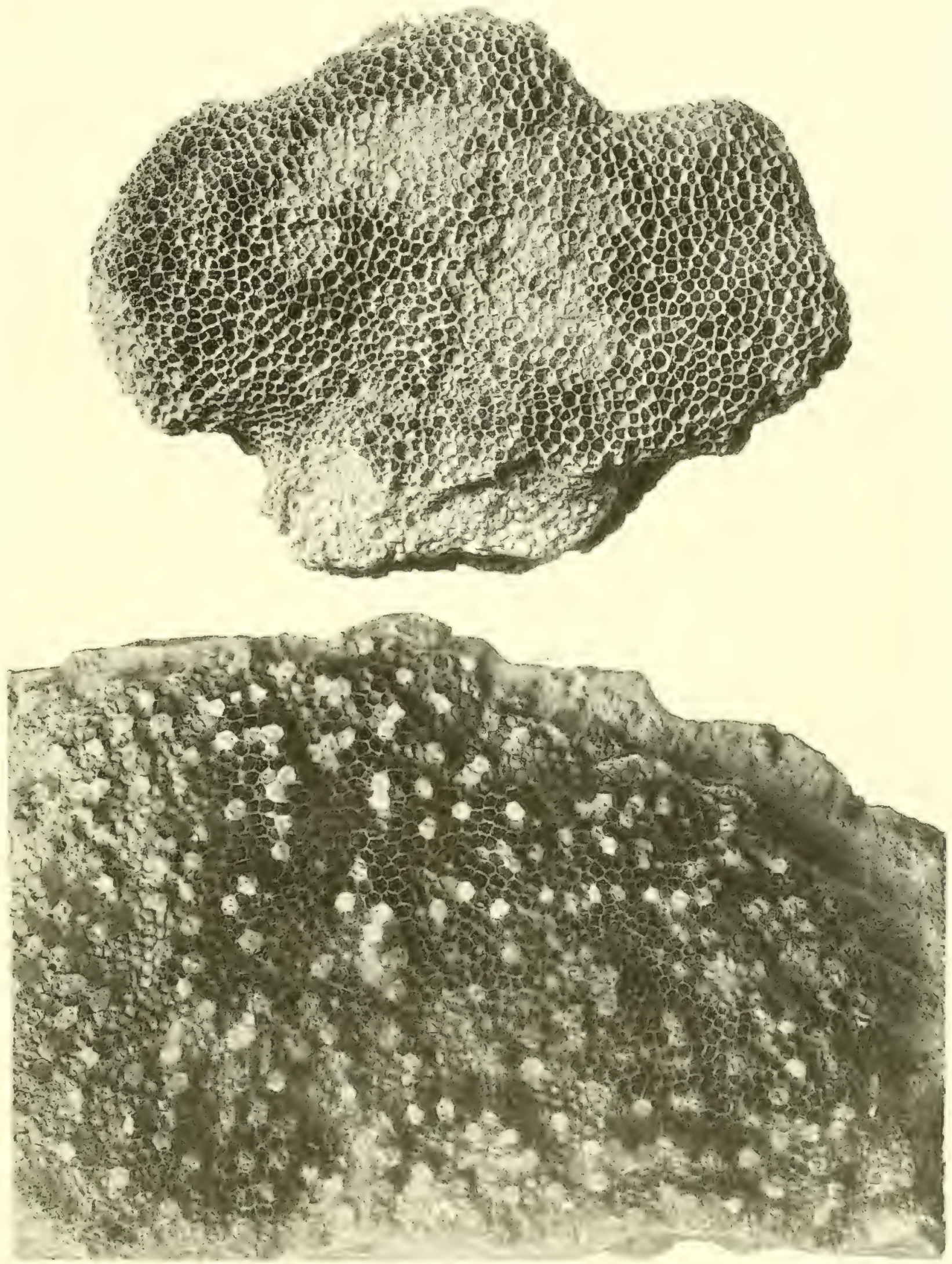




\section{PIATE VIII.}

\section{Favosites tetrerosa.}

Favosiles tuberosa Rominger. Geological Survey uf Michigan: lalaontology; ined.*

brtsaltica (Goldfuss) Billings. ("madian Journal, Vol. IV, p. 10s, tig. 8, 1850?.

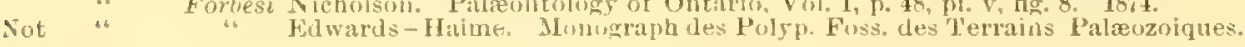

Fig. 1. View of a nuch weathered fragment, showing the projecting spine-like processes which repres int the transverse plates, and also the mural pores.

Fig. 2. View of a small clarate specimen, having umsually small cells (perhaps a distinct form).

Fig. 3. Tiew of a larger clarate specinen with large cells, and showing very distinctly the two kinds.

Fig. 4. Longitudinal section of a specimen similar to the last, showing the curving of the cells from their origin towards the outer surface, and also the mural pores and partial transverse diaphragms.

Fig. 5. View of a large solid specimen, showing the different sized cells, and also the imperfect transwerse septa, presenting the aspect of rays of the cells.

Fig. 6. View of a large ramose specimen, showing the different sized cells covered by the inperfect epitheca over a great part of the surface.

Fig. 7 . Eulargement from Fig. 1, showing the imperfect and irregular spine-like processes of the ditphragms, From the Upper Helderbcrg group. The specimen fig. 2 is from Cayuga, Ontario, the others from neal' Akron, N. Y.

" This species was sent to the printer under the name of Facoxites Nicholsoni Hall, but Dr. Rominger haring stated to the author that he had already used the name $F$. tuberosa, the latter is here adopted. 

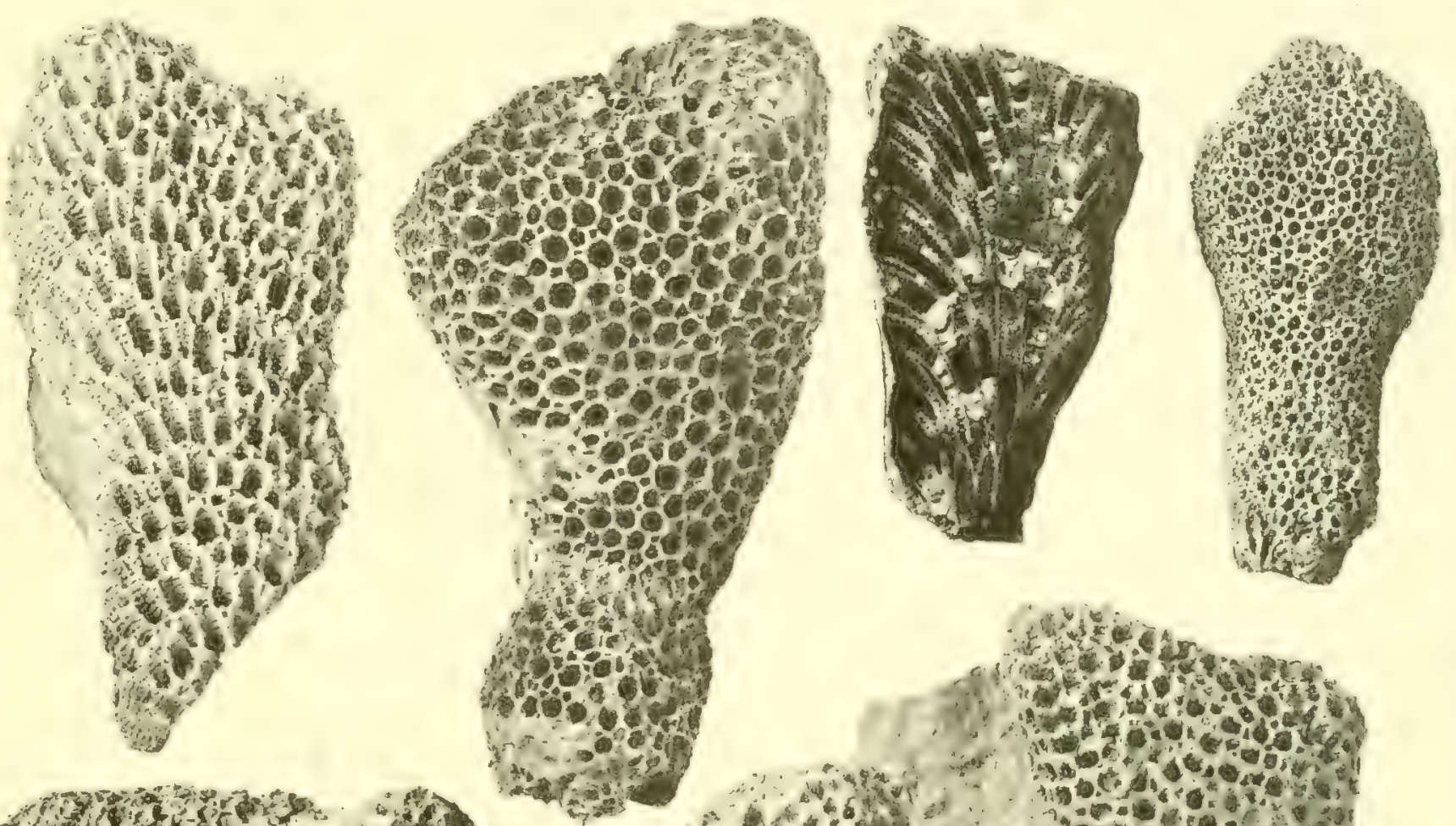

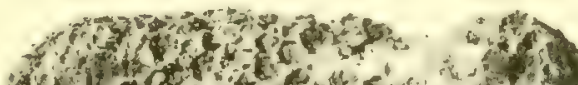
*1

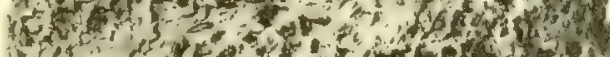
Het

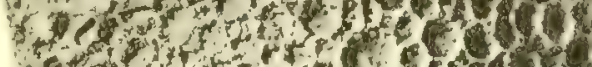

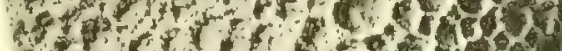
promtereat

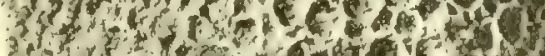

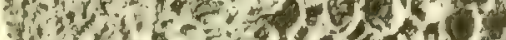
w $x^{-}=0101+5$

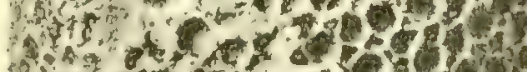

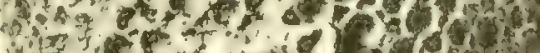
ofter ded. P $18-2+340$

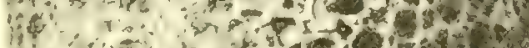

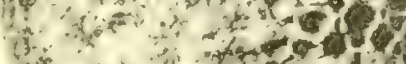

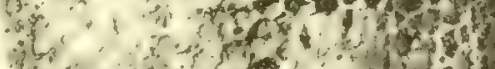

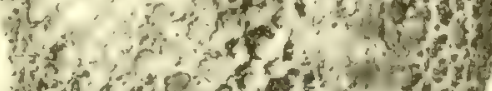

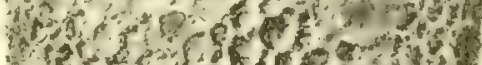

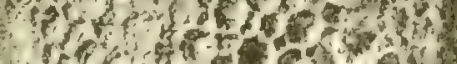

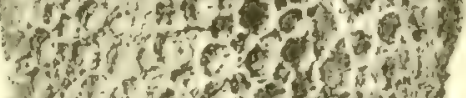
$3 x^{2}+x^{2}+x^{2}$

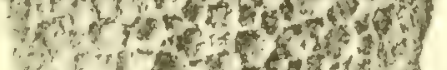

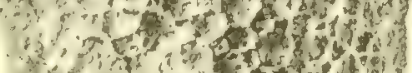

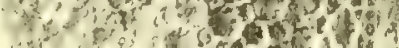
n. 004 1. 63. 100

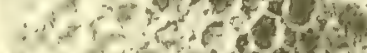
-

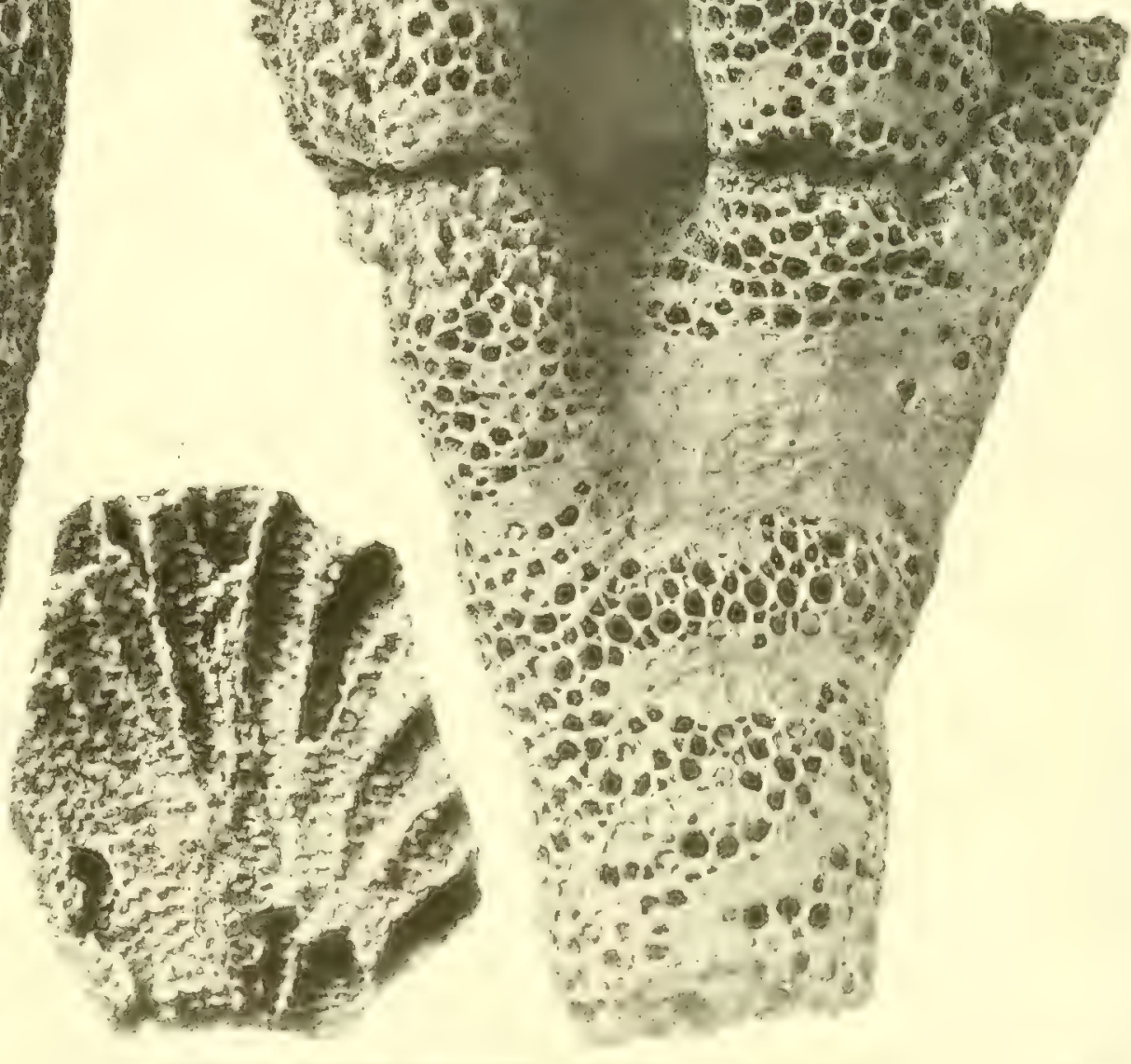

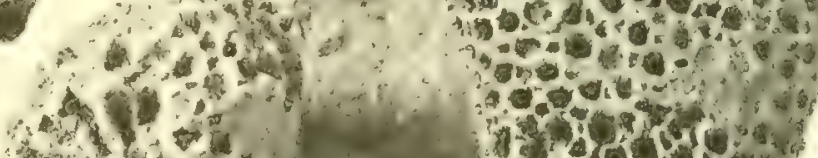
A.

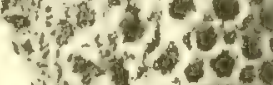

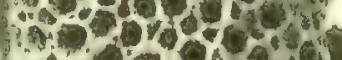
to ing a $a-1, d y$

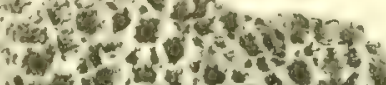

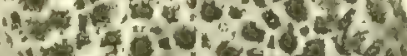

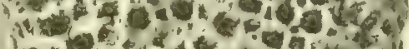


. 



\section{PIATE IX.}

Fatosites Emorit. 1]. sp.

Not Fimmonsia hemis "Forict Euss.

Not Fitosites hemispherica Yandell-Shunard, of Edwards-Haime.

Turbinate hemispheric or spreading tlattened masses.

Fig. 1. Lateral view of a small specimen, showing the two kinds of cells very distinctly.

Fig. 2. View of a larger pyriform specimen, showing the same feature as the preceding, but less distinctly.

Fig. 3. A summit view of a portion of the specimen fig. 4 , showing the larger cells projecting by the breaking away of the smaller intermediate ones. The larger cells usually have stronger walls and are better preserved in the weathering.

I'i... 4. An oblique view of a specimen, showing more distinctly the projecting larcere tubes.

Fig. 5. The upper side of a specimen where the cells are small and more equal in size.

Fin. 6. An oblique summit view of a specinen having smaller cells, but distinctly of two kinds.

Fins. 1 and 2 are from specimens from Cayluga, Ontario: 3 and 4 are from near Williamsville, N. Y., and the otner specimens are from the Falls of the Ohio.

These specinens from widely separated localities, present variations in the size and proportions of the cells, together with other characteristics which might be noticed as evidence of distinct rarjeties, or perhaps of species. 

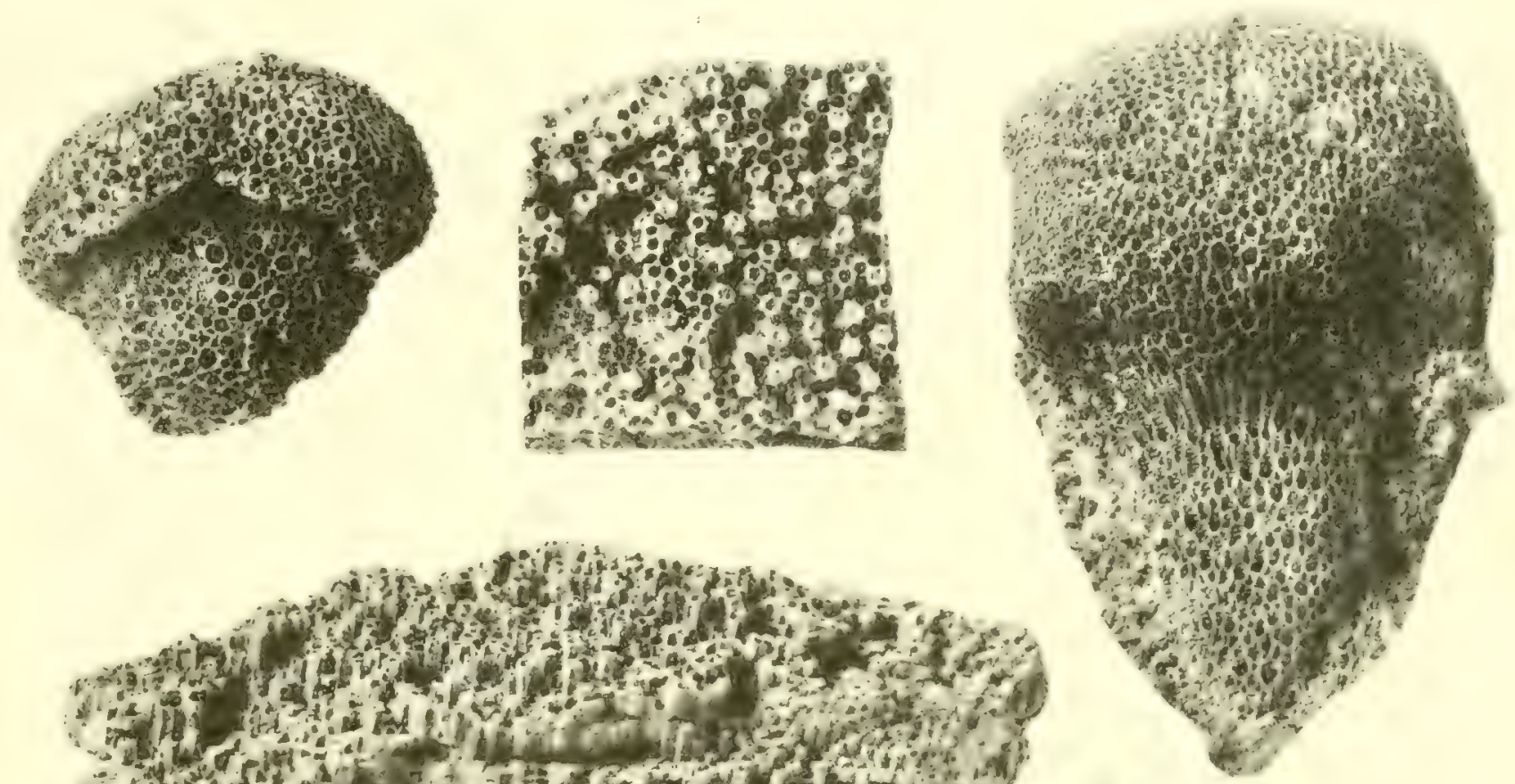

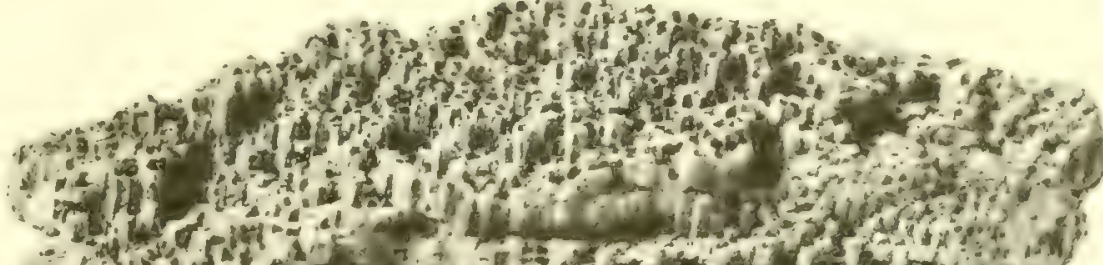

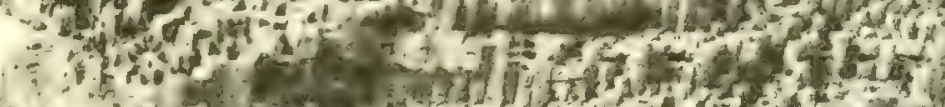

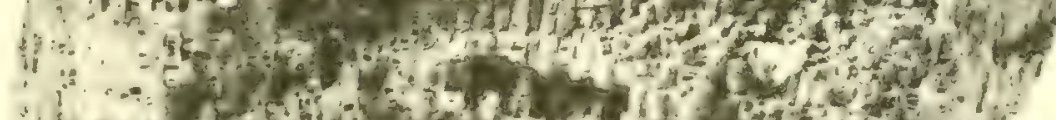

G $\left\{\begin{array}{l}1 \\ 3\end{array}\right.$
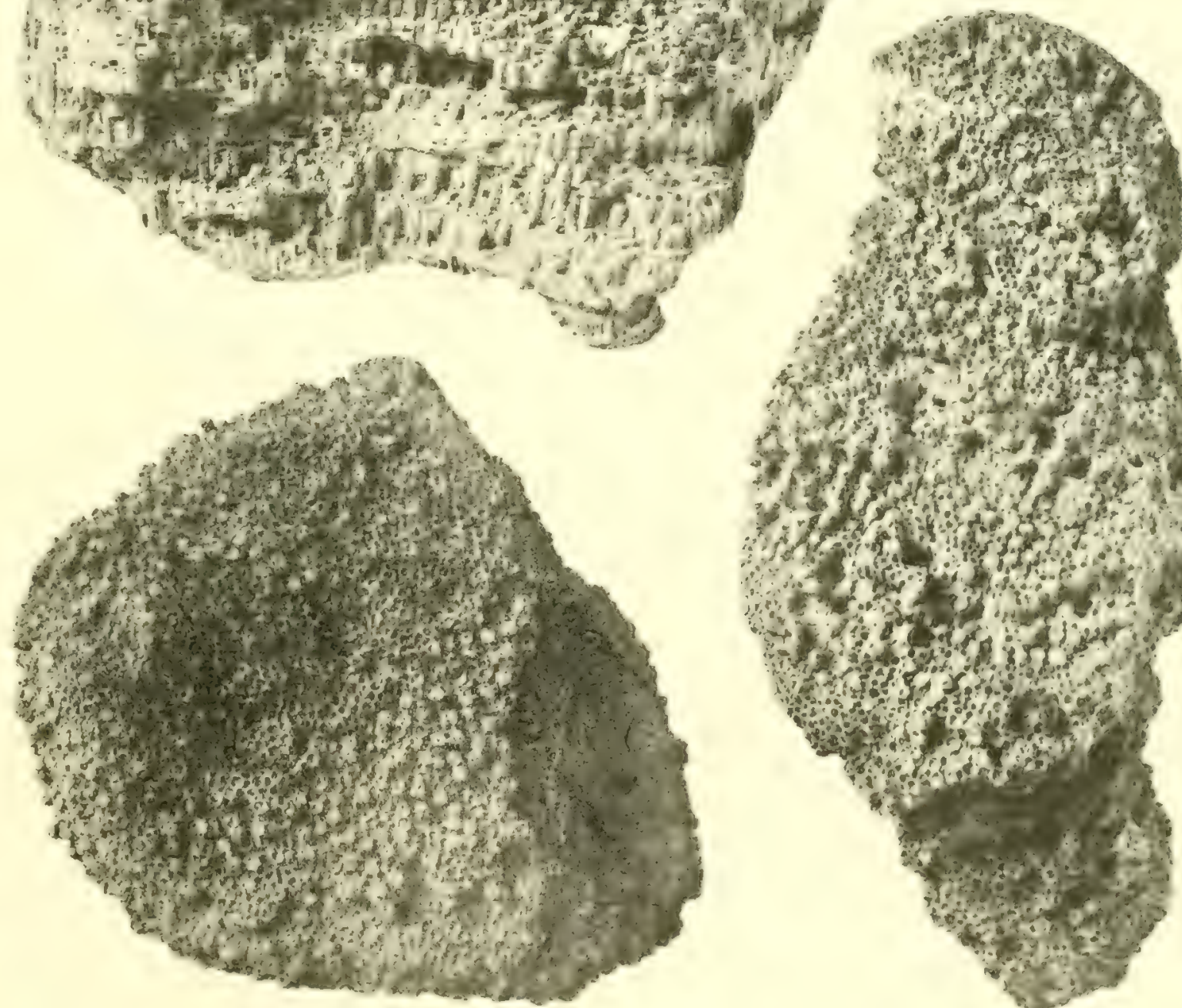

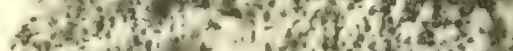
Th

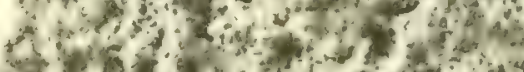

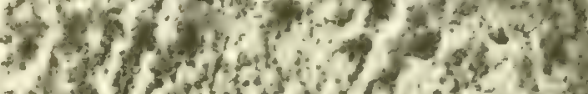

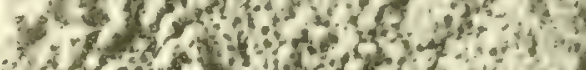

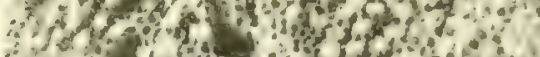

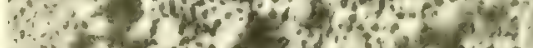

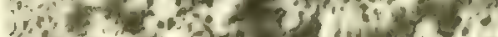

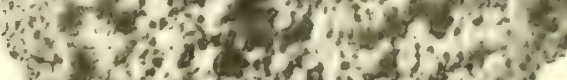

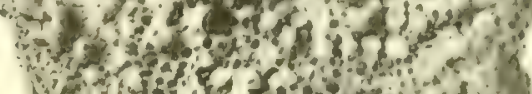

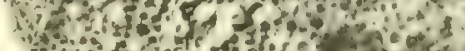

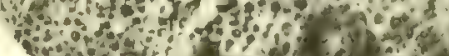
wi

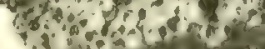
क्षे

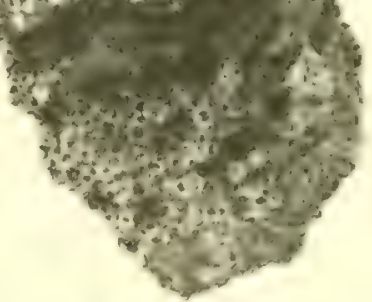





\section{PIAATE X.}

\section{Fayosites epiderimata var. corticosa.}

Furosites epidermata Rominger, in part.

Fin. 1. View of a large specimen which is broadly turbinate at the base and divides into several branches above, the whole covered by the characteristic epitheca.

1'i... 2. A weathered section, cutting obliquely across the upper part of a broad cyathiform speci. men, showing the transverse diaphragms.

Fir. $\therefore$. View of the opposite side of the sane. showing the peculiar epitheca very strongly marked.

Fi... 4. View of a narrowly turbinate bud or branch, which is sulcated along the middle, showing a tendency to division.

Fin. ¿. A longitudinal section from the specimen fig. 4 , showing a small form of the cell with closely arranged diaphragns.

Fig. 6. An enlargement of several open cells of a large celled vartety of this species, showing the incomplete diaphragms and mural pores.

\section{Fatosites IIEMISPHERICA.}

(For references, see Explanation of Plate 2.)

Fig. 7 . Au enlargement of a part of a specimen with open cells, showing the characteristic single range of pores. The transverse diaphragms have been removed in the process of silicification. 


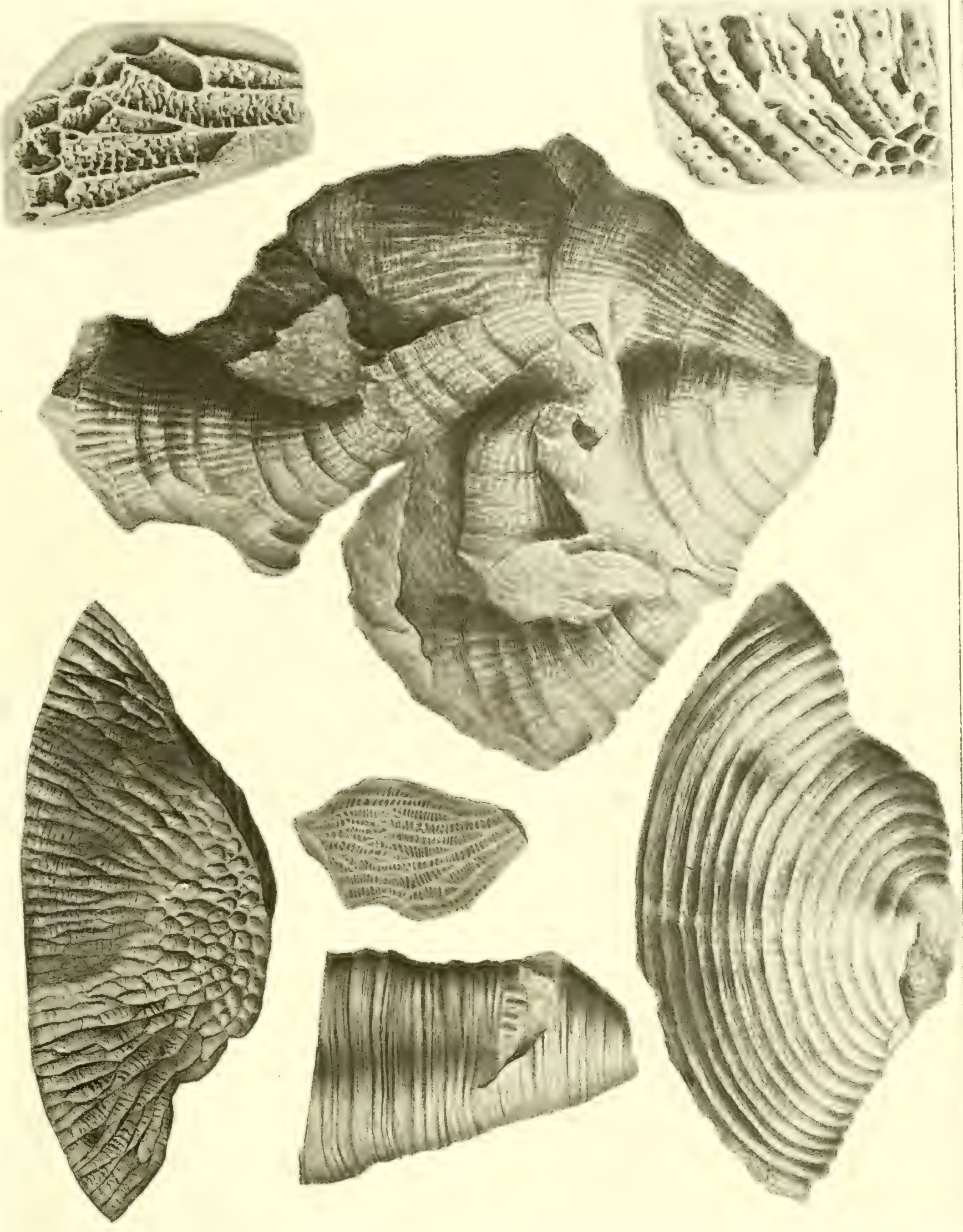






\section{PLATE XI. \\ Favosites tuberosa.}

Fig. 1. An enlargement of a part of the longitudinal section * of fig. 4, plate 8, showing the entire and incomplete diaphragms and the large mural pores.

\section{FAvosites heMispherica vaĩ. TURBINATA.}

Fir. 2. An enlargement from the cells of the same specimen represented in section fig. 4 , showing the partial diaphragms, which give a radiated appearance to the cells.

Fig. 3. A longitudinal section enlarged from the same specimen, showing the distant entire diapliragms.

Fig. 4. A longitudinal section, natural size. The specimen is of the same form as fig. 4, plate 23 , and is from the Upper Helderberg group at Sandusky, Ohio.

\section{Farosites Eymoxit.}

Fin. 5. An enlargement of a fragment, skowing the complete and imperfect closely arranged diaphragms.

\section{Favosites Inemispherica.}

\section{(See also Plates : and $2 A$.}

Fi.. 6. An enlargement of a longitudinal section of a specimen with open cells and distinct small pores, corresponding in form to those represented by figs. 4 and 5 , Plate 2.

Fig. 7. A longitudinal section corresponding with fig. 6 , but not showing mural pores.

Fig. A. An enlargement from a weathered section of the specimen fig. 8 , plate $2 \mathrm{~B}$, showing the transverse diaphragms and the sirgle row of mural pores. This specimen has all the characteristics of those referred by Eaton to Cyathophyllum quadrigeminum; the weathered cells presenting the stellate character represented in his figure.

Fig. 9. An enlargement of a rertical fractured surface, showing the form of the sides of the cells, the disposition of the mural pores and the transverse strix.

Fig. 10. An enlargement of a vertical section (of this species?) where the cells are open, showing both entire and incomplete diaphragms.

\section{FAvosites epinerdata var. CORTICOSA.}

\section{(See also Plate 10.)}

Figs, 11 and 12. Trausverse and longitudinal sections of a flattened branch of this species, showing the size of the cells and the transverse diaphragms.

* Figures are referred to as longitudinal sections when representing a cut parallel to the longitudinal direction of the cells, and a cutting from base to summit is referred to as a vertical section. 

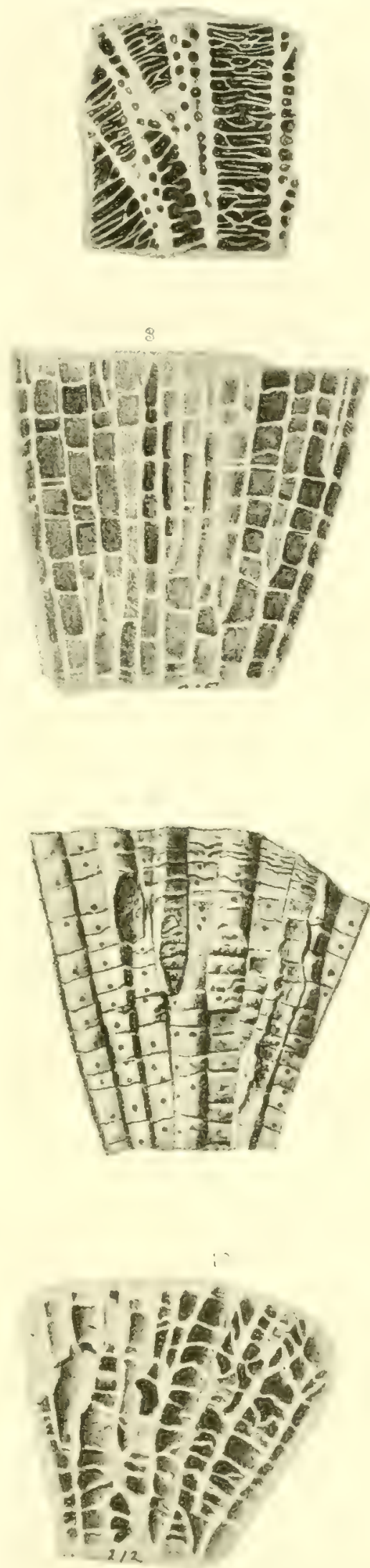
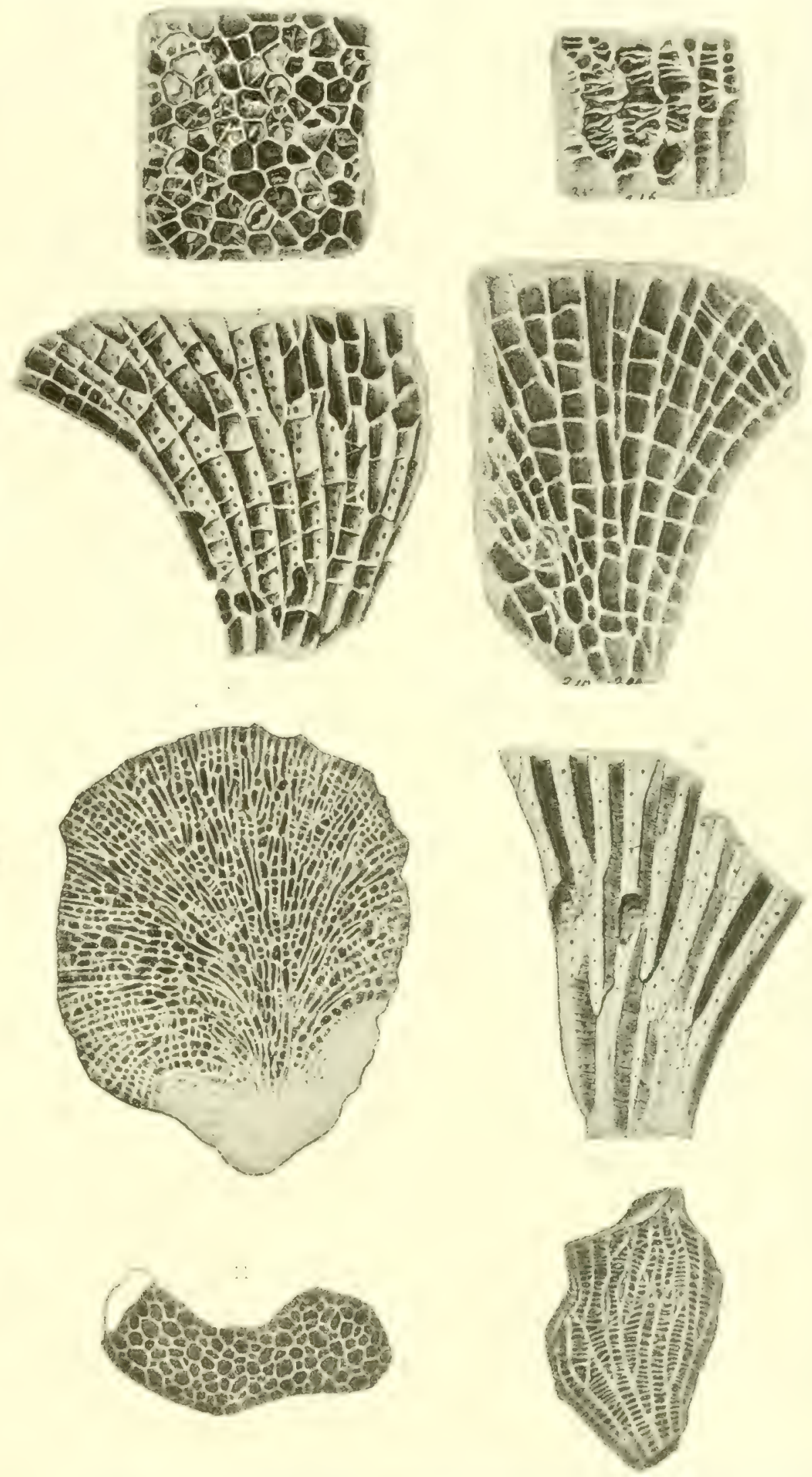



\section{PLATE XII. \\ Fatosites Emmonsit. \\ (See also Plates 9 and 11.)}

Fig. 1. An enlargement of a longitudinal section, showing the transverse diaphragms, both entire and incomplete, and also the mural pores. Falls of the Ohio.

Fig. 2. An enlargement of a specimen showing more continuous diaphagms, which are coated with erystals of silex. lieferred with doubt to this species. Cayuga, Ontario county, N. Y.

Fig. 3. An enlargement of a weathered surface of a specimen, showing closely arranged diaphragms and single range of pores. From Livingston county, N. Y.

Fig. 4. An enlargement from a polished vertical section, having all the external characters of the species, showing the diaphragms mostly complete and the pores large and closely arranged. Probably a distinct species. Falls of the Ohio.

Fig. 5. An enlargement of a polished rertical section of a variety having very small cells and partial diaphragms. Falls of the Ohio.

\section{FAVOSITES EPIDERMATA.}

(See also Plates 6 and 10.)

Fig. 6. The lower sicle of a small, abruptly spreading variety, from Cayuga, Ontario.

Fig. 9. Oblique riew of the cell-apertures, enlarged from a specimen similar to fig. 6 , showing the characteristic strix of the cell-walls and the projecting points representing the diaphragms.

Fig. 10. Enlarged view of the upper surface, from the specimen fig. 6, showing complete diaphragms which are distinctly depressed at the angles. (This feature is not well shown in the figure.)

Fig. 11. An enlargenent from a weathered decorticated surface of the under side of the specimen fig. 6 , showing the projecting points or remains of diaphragms, the faint strire and the mural pores, the latter distinctly sutrounded by an elevated border.

Fig. 12. An enlargement from the weathered surface of the specimen fig. 5, plate 6, showing the closely arranged imperfect diaphragms.

Fig. 13. An enlarged section of a polished surface of the same specimen (fig. 5, pl. 6), showing the very numerous diaphragms which often coalesie, and give a vesiculose structure to the fossil.

\section{FAVOSITES TUBEROSA? \\ Farosites nubrosit Rominger \\ See Plutes 4, $\pi, 8$ and 11.)}

Fig. 7 . An enlargement of a polished rertical section, showing both entre and incomplete diaphagms and strong cell-walls. The exterual character of the cells is entirely similar to the following form.

Fig. 8. An enlargement from the upper surface of a specinen fig. 1, plate 4, slowing the imperfect diaphragms giving a stellate appearance. 

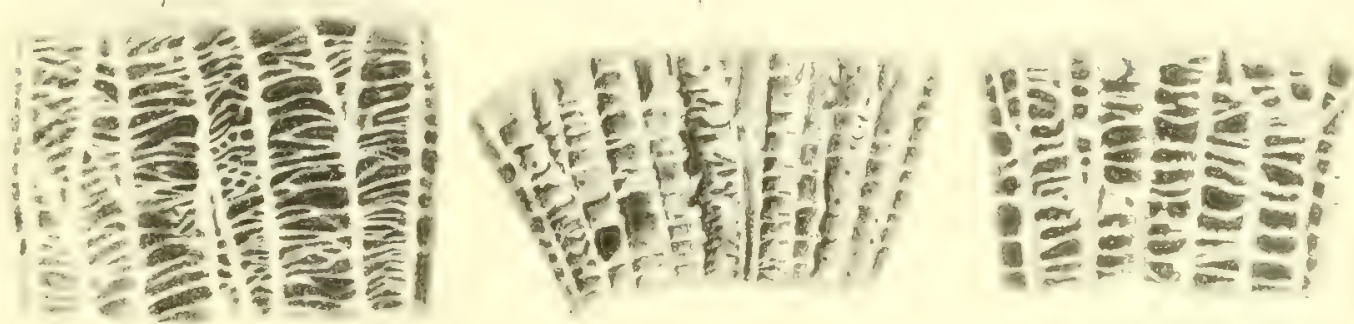
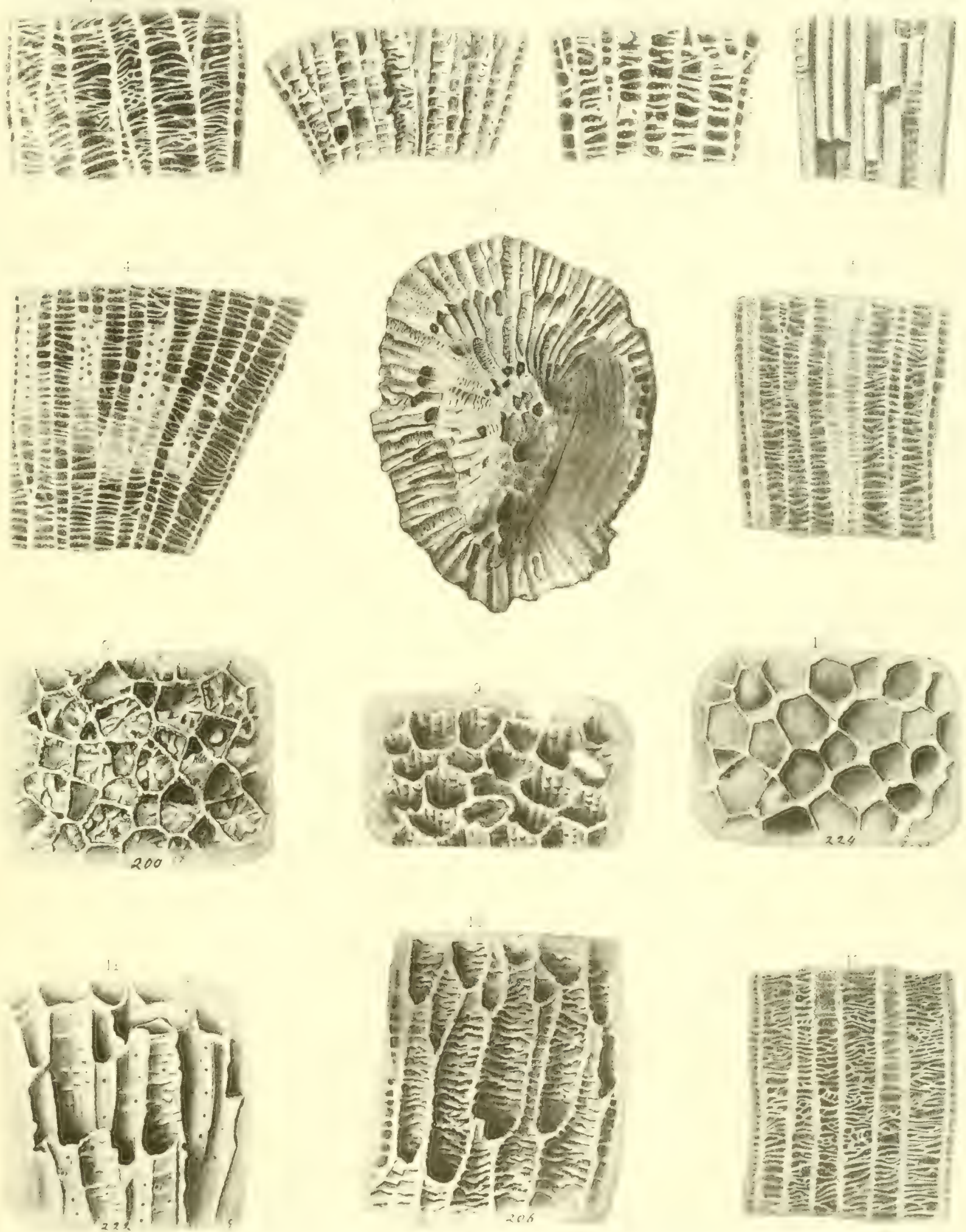


\section{,}




\section{PLATE XПII.}

\section{Favosites? Argus n. sp.}

Fi... 1. Lateral view of a small subclavate specimen, showing the larger cells somewhat crowded in places.

Fit: 2. A lateral view of a broader pyriform speciusen, having the larger celis less numerous.

Fin. .). View of an irregularly growng pyriform specimen, where the larger cells are numerous and strongly exsert.

Fir. 1. The upper side of a large depressed hemispheric form, where the larger cells are distant and conspicuous.

Fy. : . A vertical section of a specimen where the cells remain open, but finely coated on the interior, and showing the clusely arranged, often crowded diaphragms.

Fir. 4;. A vertical section ol another individual mass, showing the mode of increase of the cells and the striation of the surface, which produces the crenulations of the partition walls at the aperture, as seen on figures 8,9 and 10. In this specimen the diaphragms are more distant ihan in fig. 5.

Fi:. 7. An enlargement of a fragnent from the same mass as fig. 5 , showing the pores of the cell-walls - a feature rarely observed. In this case the pores were revealed by partially calcining the specimen, so as to bleach the substance of the cell-wall.

Fig. 8. An enlargement of the surface from a beatifully weathered specimen. In the figure the walls appear flattened on the surface instead of sharply carinate as in the example.

Fir. 9. An enlargement of a transverse section near the surface of a specimen, showing the thickness of the walls and their crenulated sides.

Fig. 10. An enlargement of the surfuce looking obliquely across it. The larger cell-mouths, as represented, are too much elevated and their sides too spreading.

\section{Fatosites? sp.}

Fig. 11. A lateral view of an irregularly growing specimen, showing the general form and size of the cells. The crenulations which are quite strong, are not apparent in the figure, which is too small to show them properly. No pores lave been observed in the cell walls, and the specimen has been referred with doubt to the genus Beaumontia. 


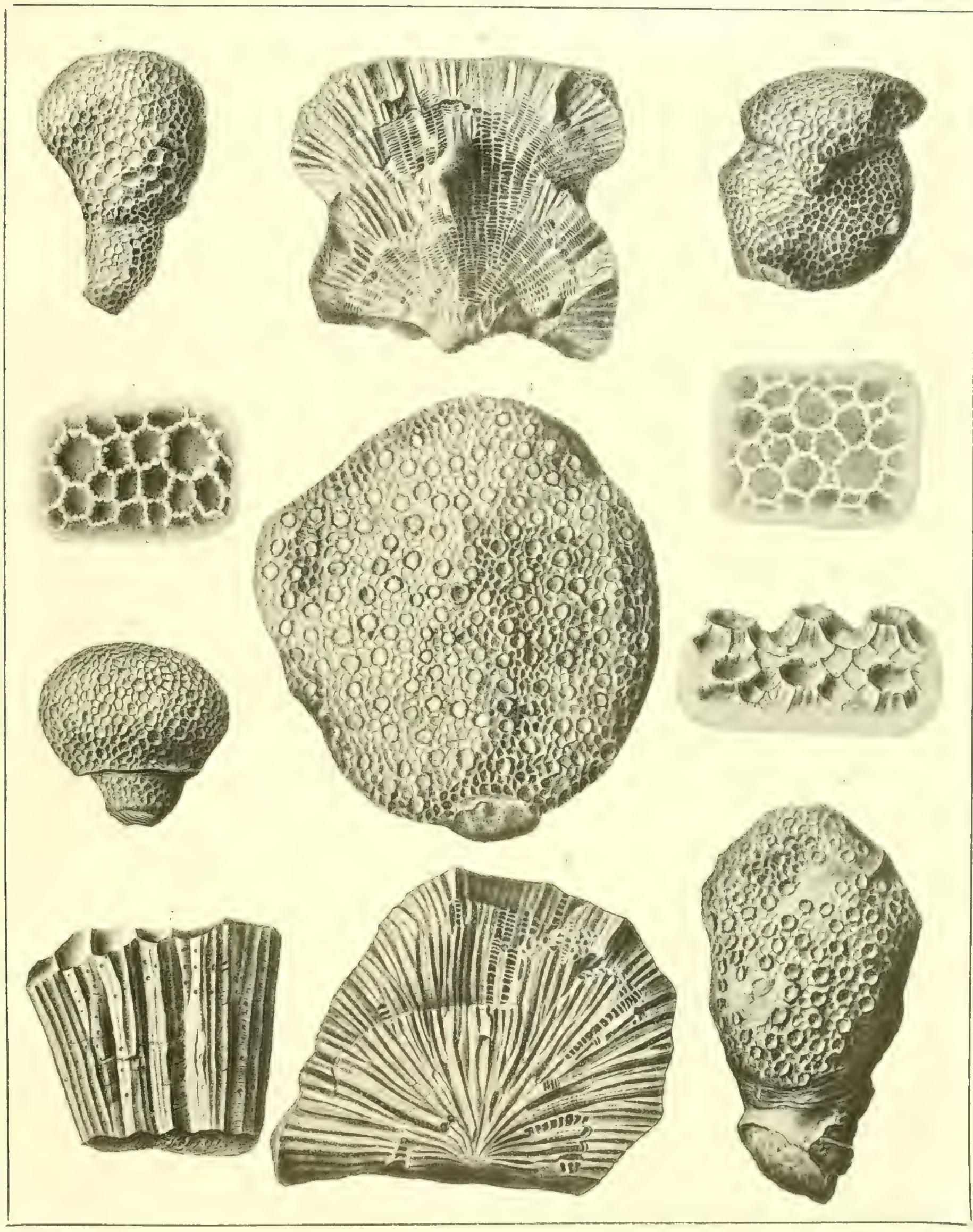





\section{PLATE XIV.}

\section{Favosites (Michelina :) explanata. n. sp.}

Fig. 1. A part of a circular depressed hemispheric mass, the upper side having the cell-apertures, with few exceptions, subequal and crenulate on the margins.

Fit. 2. The lower side of the same specimen where the cell-apertures are very unequal.

Fig. 3. An enlargement of a section from the lower right side of fig. 2, showing the origin and mode of growth of the cells, the diaphragms, and a few pores on one cell-wall; all the characters being more like Michelina than like Favosites.

Fig. 4. An enlargement of the cell-apertures from the specimen figure 1.

\section{Alveolites GoldFussi.}

Alveolites Goldfussi Billings. Cauad. Journ., New Series, Vol. V, p. 255. 1860.;

Figs. 5, 6. The upper surface of two individuals, showing some diference in the proportion and character of the cell-apertures.

Fig. 7 . An enlargement of the surface from the specimen figure 6 .

Figs. 8, 9. A farther enlargement of the cell-apertures from the specimens figures 5 and 6. 

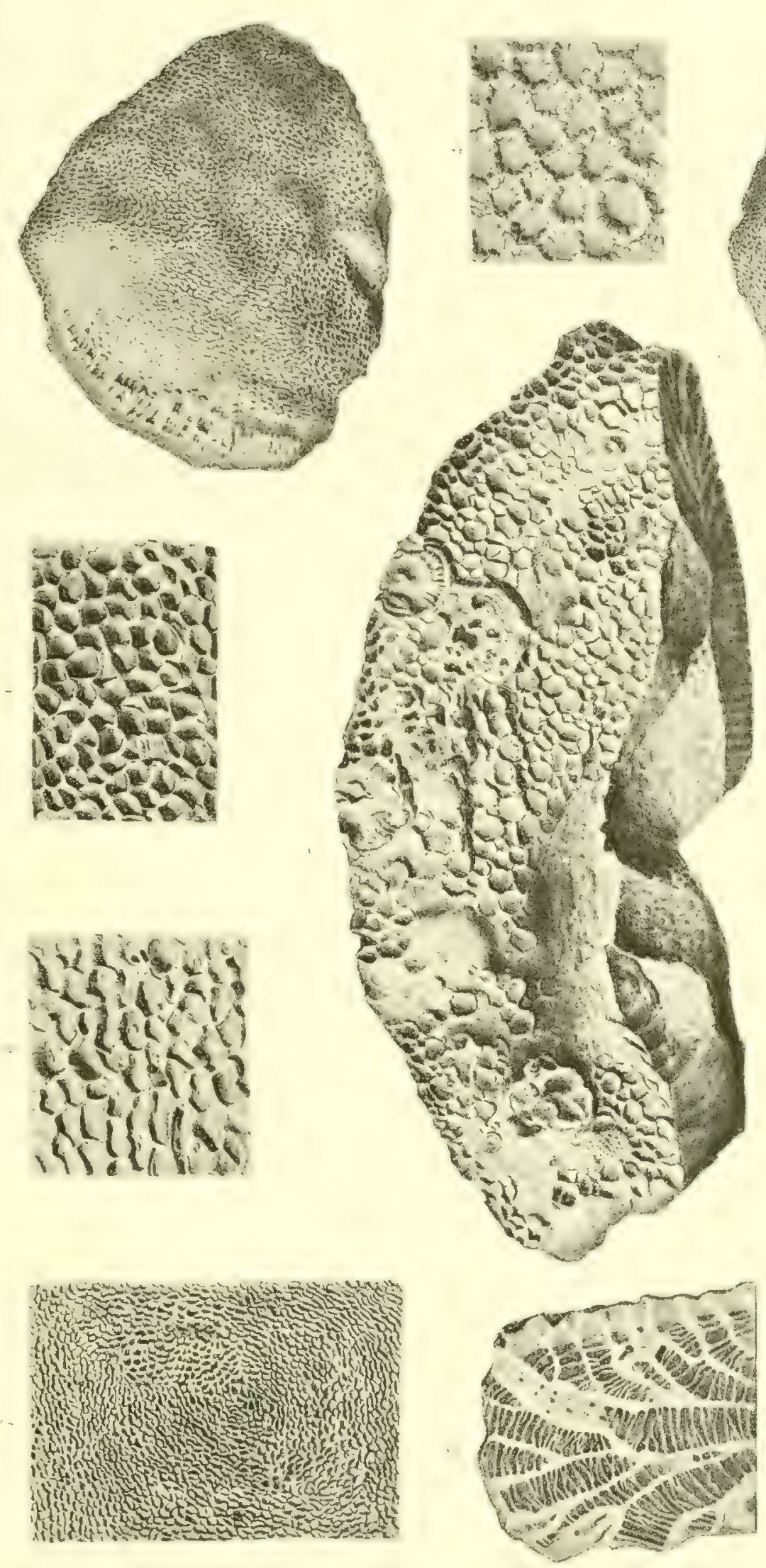
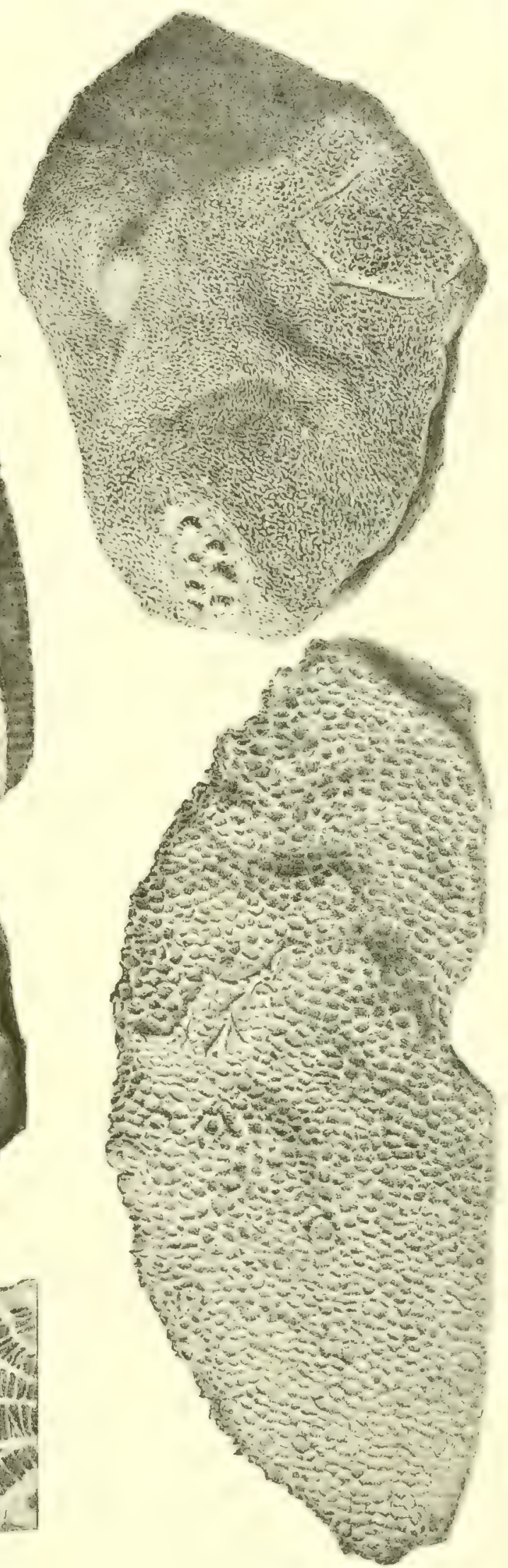



\section{PLATE XV.}

\section{Michelina (Pleunodictyum) convexa.}

\section{Michelina convexa D'Orbignt. Prodrome de Pulrentolorie, Vol. 1. p. 10\%.}

" "Edw,-Haime. Polyp. Foss, des Terrains Palæozoiques, p. 251, pl. 16, f. 1.

". Billings. Canadian Journal, New Series, Vol. IV, page i1:. 1859.

Fig. 1. The weathered summit of a specimen presenting principally the apertures of the large cells which preserve the strix upon their inner surfaces, with diaphragms nearly all complete.

Fig. 2. The weathered surface of a turbinate form, showing the partial and more or less complete convex diaphragms.

Fig. 3. The summit of a larger individual, showing the variable size of the cells, the interior stria tion and the more or less complete convex diaphragms.

Fig. 4. An obliquely vertical section, produced by wear and weathering, and preserving the longitudinal strix, the connecting pores and the margins of the diaphragms.

Fig. 5. A vertical section, cutting the cells longitudinally, and showing the vesicular structure of the diaphragms.

These figures present illustrations of the common forms of the species as they occur in the Upper Helderberg limestone in New York, Ontario, Ohio, Michigan, and at the Falls of the Ohio in Indiana and Kentucky. 

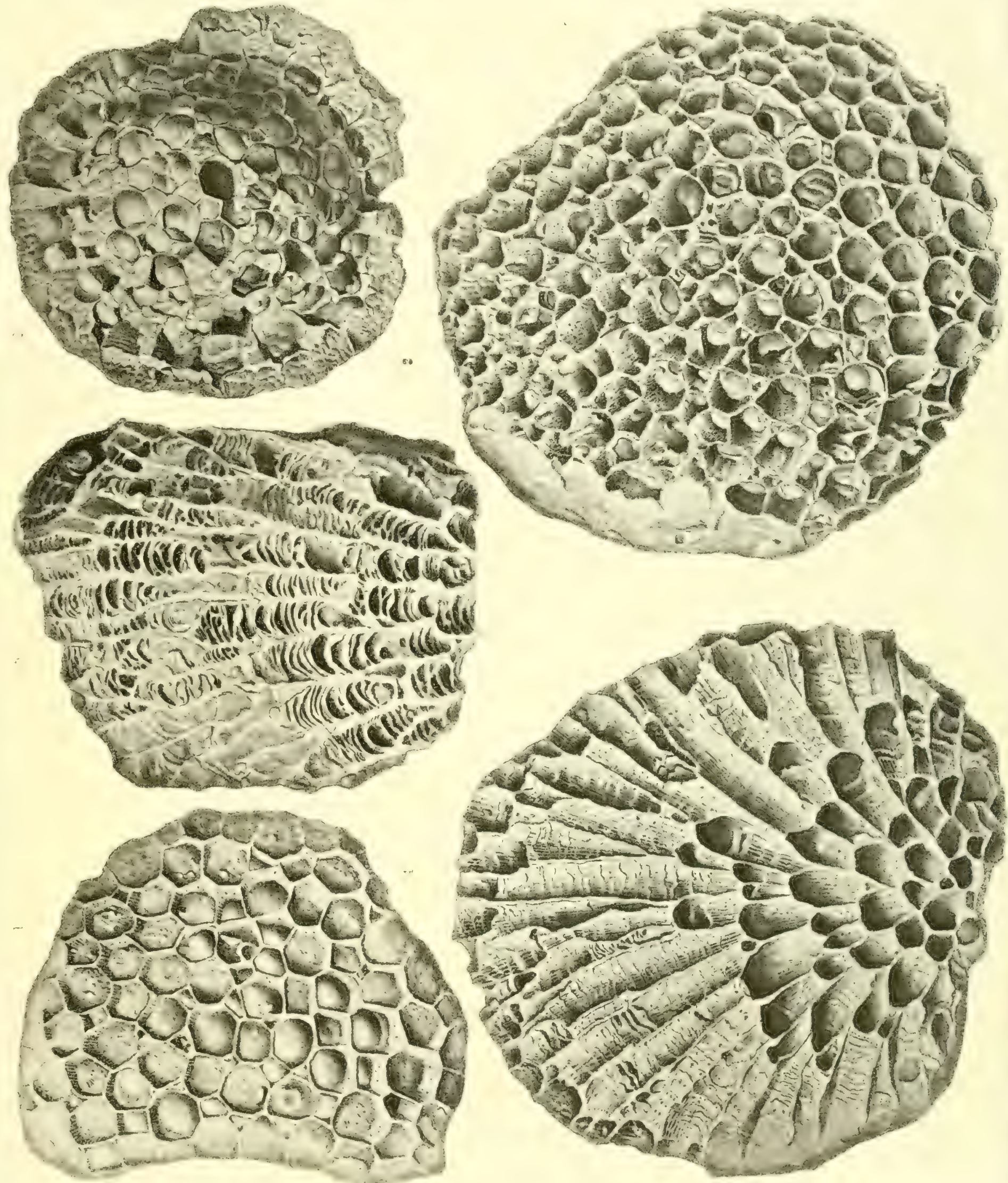



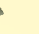




\section{PLATE XV A. \\ Michelina (Pletrodictium) convexa. \\ (See Plate 15, for references.)}

Fig. 1. A large and unusually cylindrical form of this species, as it occurs in the Corniferous limestone of Ontario. The diaphragms are very convex and vesicular.

Fir. 2. A small specimen, preserving its broad subconical form with deep striated calyces.

Fir. 3. A young group with deep strjated calyces and very conrex diaphragms.

Fig. 4. A lateral view of the preceding specimen.

Fir. i. The basilar portion of a young group in which none of the cells lave attained the full size, and with scarcely an evidence of diaplaragms preserved.

Fig. 6. The under side of the preceding specimen, showing the pustulose epitheca, the growth haring commenced on what appear to have been some broken cells of the species.

Fir. 7. An enlargement of some solid columns or filling of cells, preserving the striated surfaces and minute pores.

Fig. 8. A single cell enlarged to show the striæ and minute connecting pores, and the continuous diaphragoms.

Fig. 9. An enlargement of several columns or cell-fillings in limestone, showing the stria and irregular connecting pores.

Fig. 10. An enlargement of some weathered open cells which preserve the stria and the margins of some of the diaphragms, but show no connecting pores.

Fig. 11. The base of a young colony, showing the walls perforated with numerous pores, but without evidence of diaphragms. 

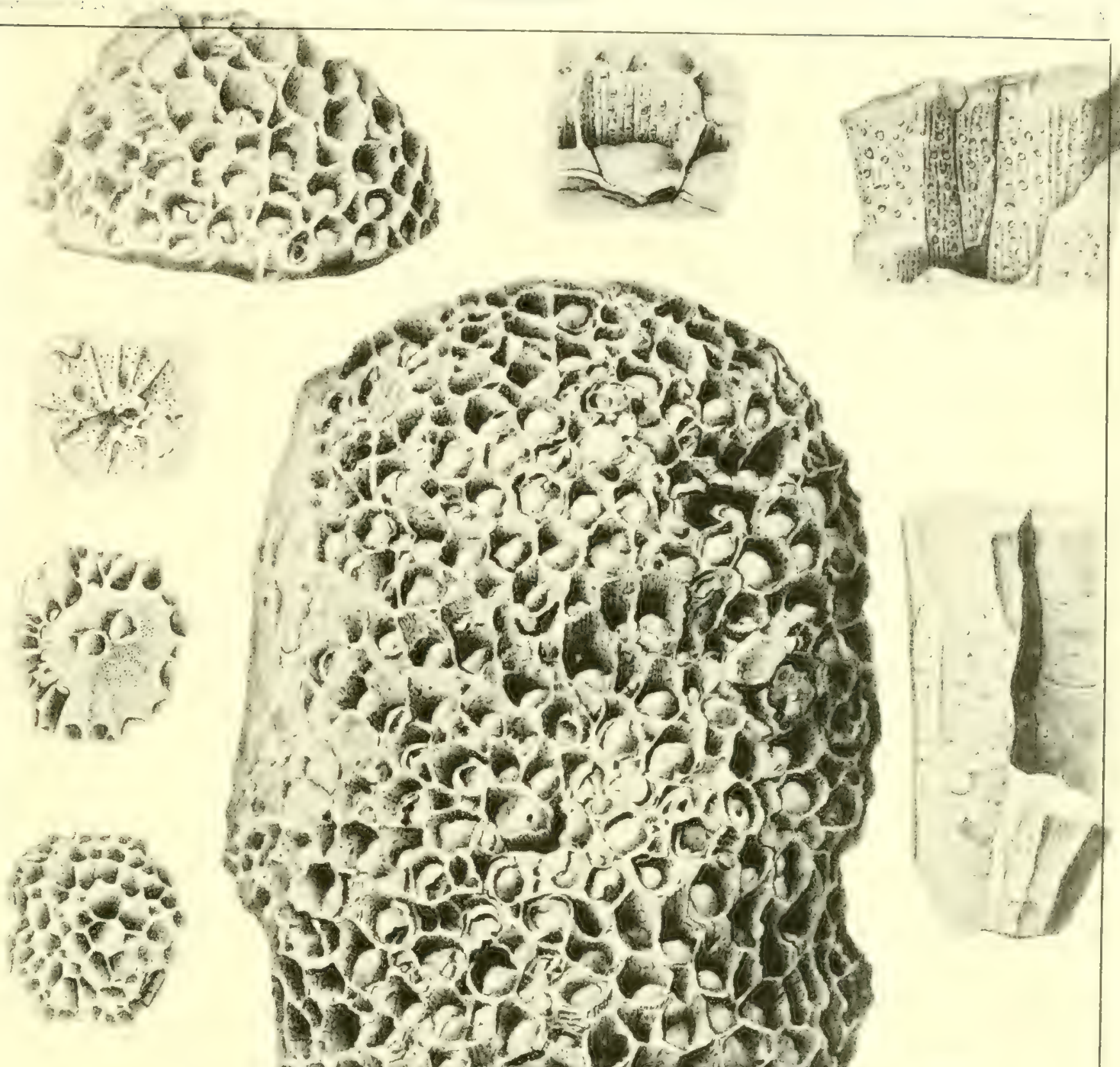

$110,2=6$
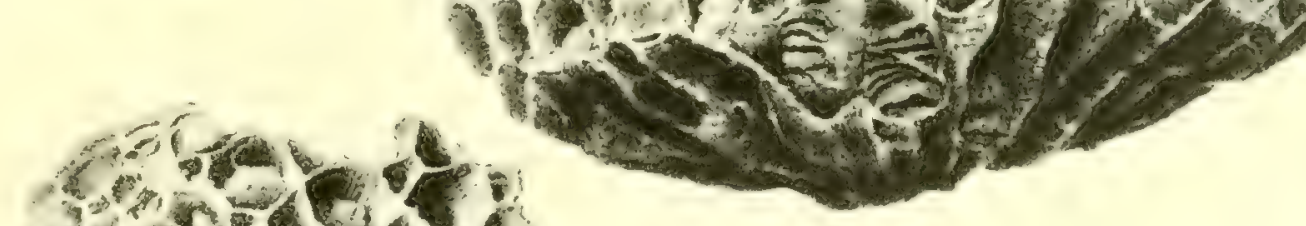

$+a^{3}-1040$

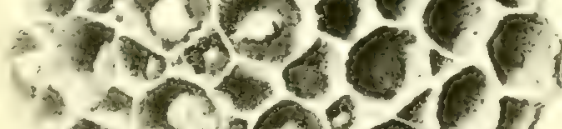

- C.P.

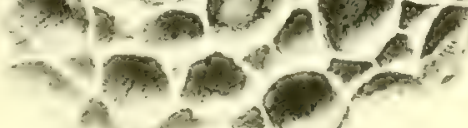
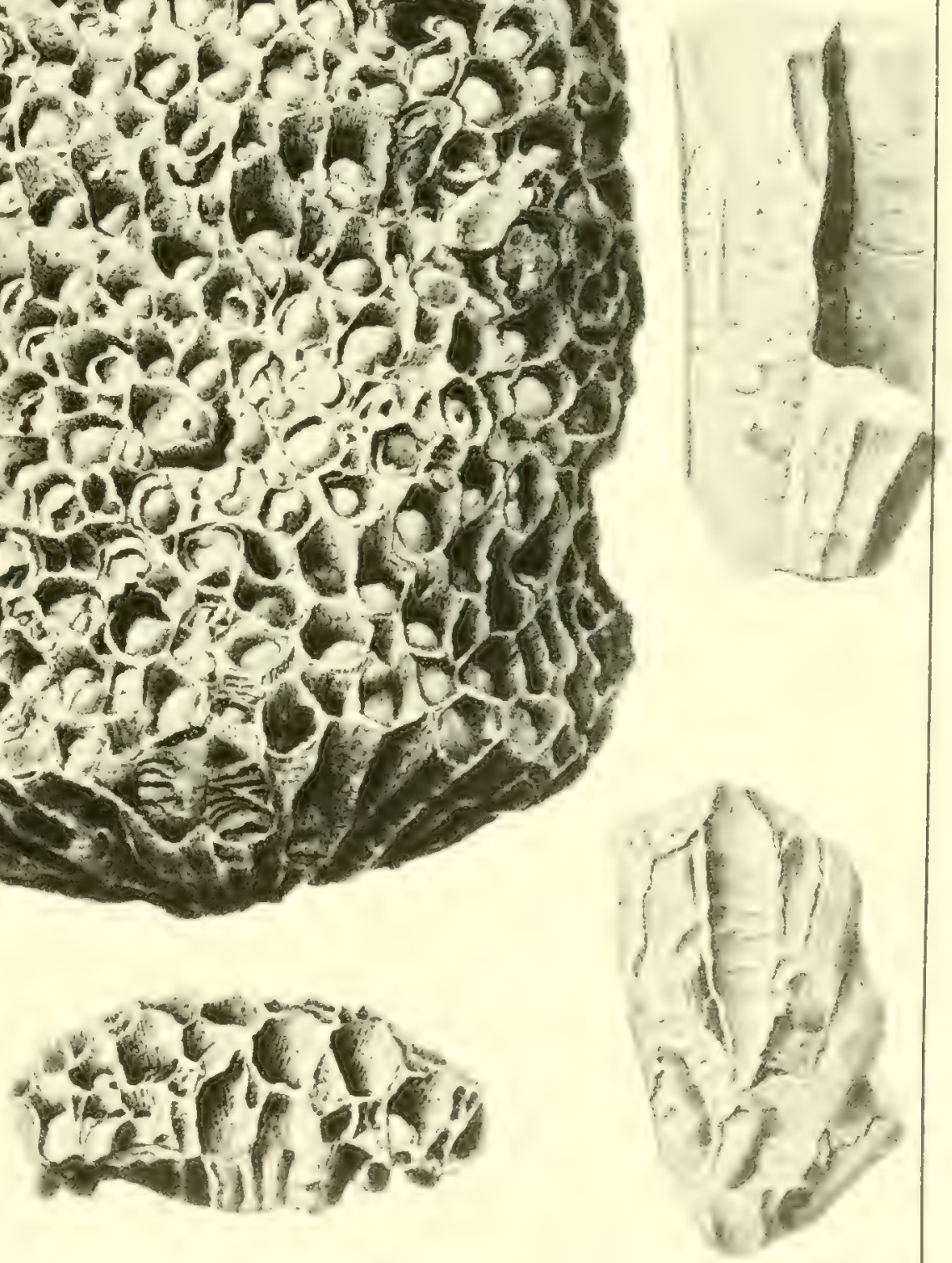




\section{PLATE XVI.}

\section{Michelina (Pleurodictivum) maxima.}

Calamopura maxima Troost. Geological Report of Temnessee, page 53.1840.

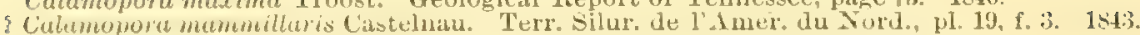

? Farosites maximu Troost: in Owen's Rep. on Geol. Iowa, Wisconsin aud Illinois.

" "

mammillaris Ldw. - Haime. Polyp. Fossiles des 'Terrains P'alieozoiques, page:"41.

Fig. 1. A portion of a larger hemispheric mass, presenting the usual characters of the species. The diaphragms are often mammillary or pustulose on their upper surface, as shown in this figure.

Fig. 2. A fragment showing numerous small cells alternating with larger ones.

Fig. 3. An enlargement of the cells from the upper surface of a specimen, showing partial and complete diaphragms with pustulose surfaces.

Fin. 4. A longitudinal section of a solid mass, showing the minute pores in the walls of the cells.

Fig. 5. An enlargement of several of the solid columns, to show the longitudinal strix and minute pores.

Fig. 6. A longitudinal section of a portion of a solid mass enlarged, showing interrupted and contimuous diaphragms.

Fig. 7. A section of a solid mass, showing the crowded complete and partial diaphragms, and exhibiting the pores in some of the cell walls. 

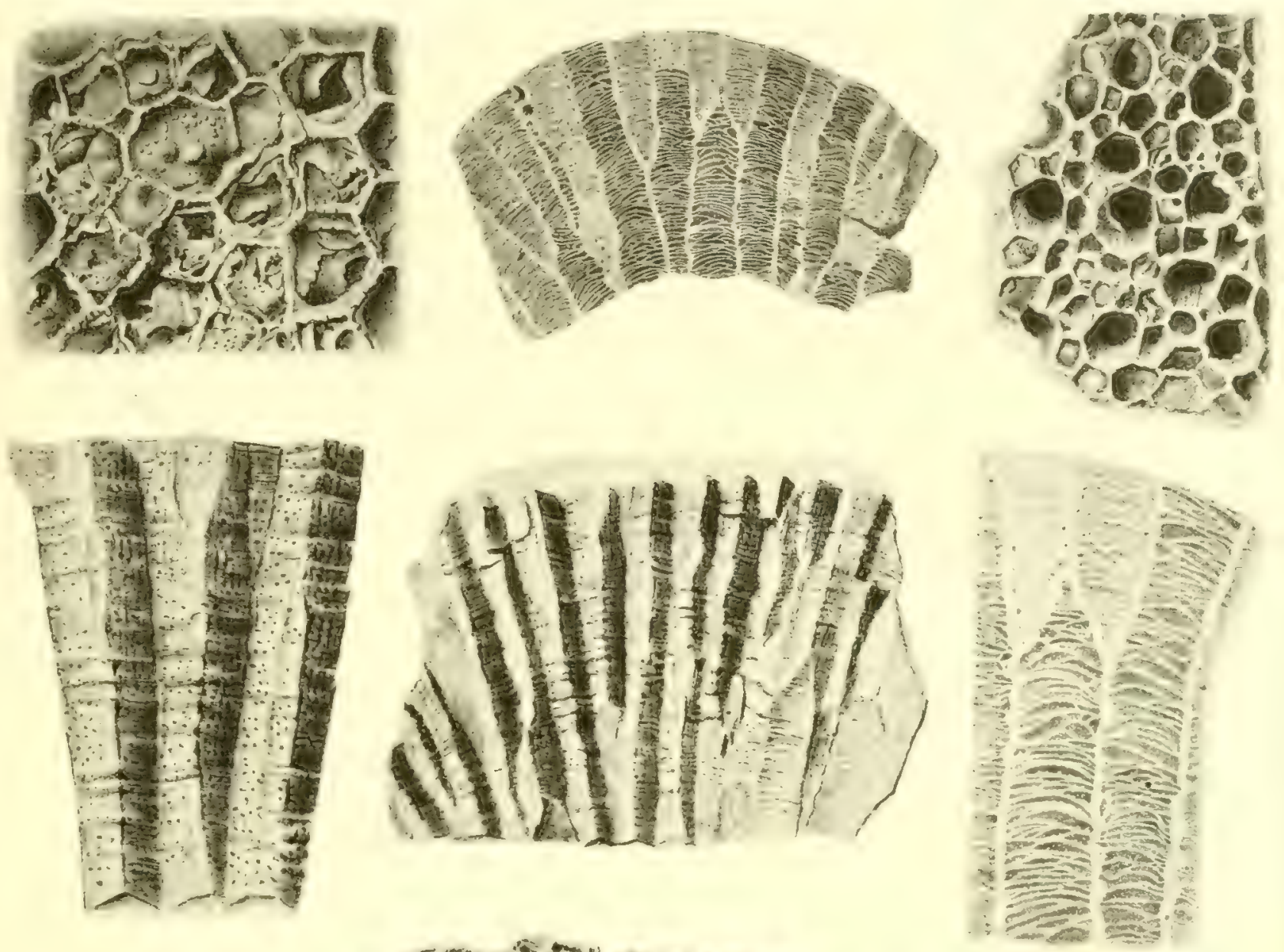

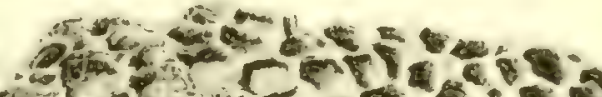

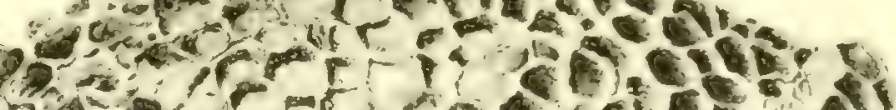

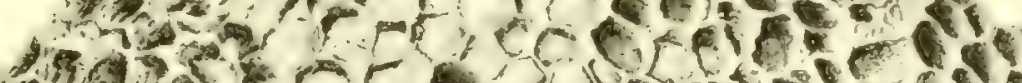
anition

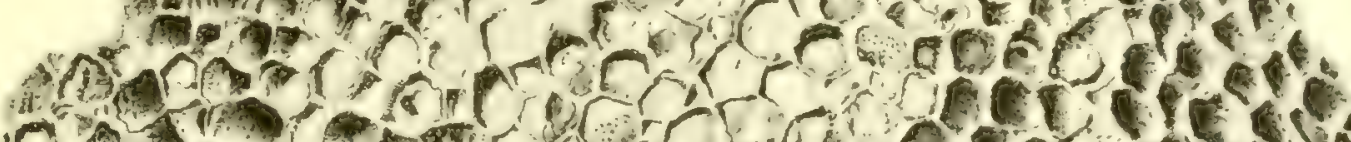

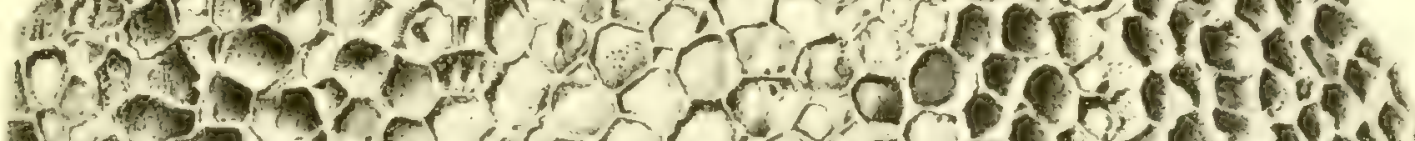

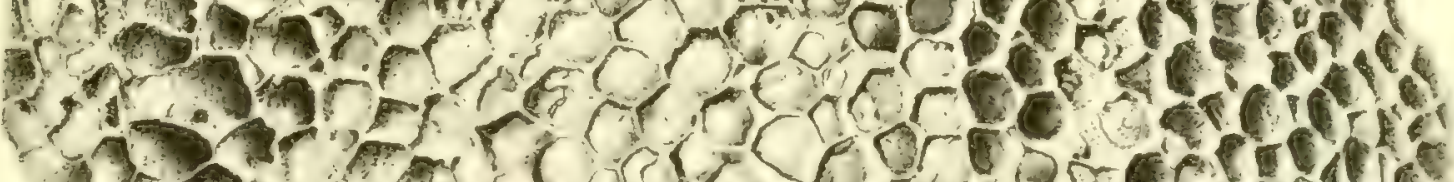

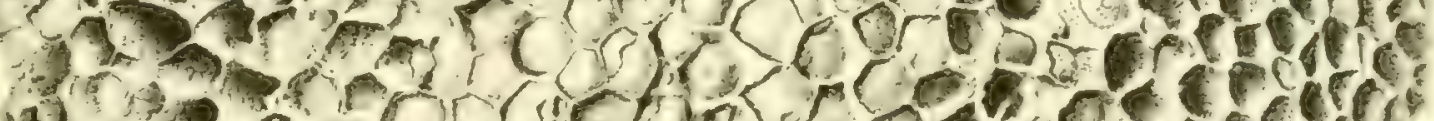

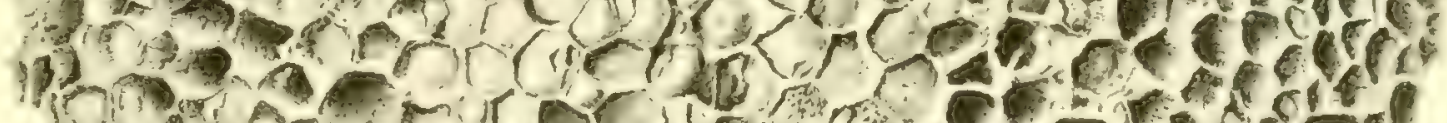

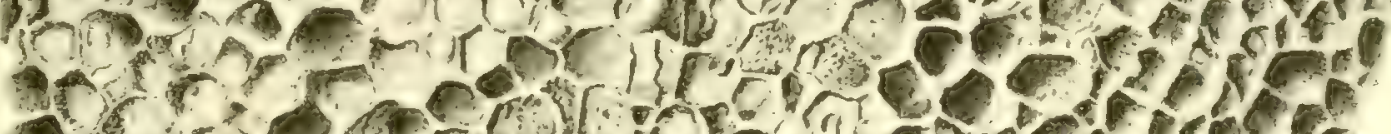

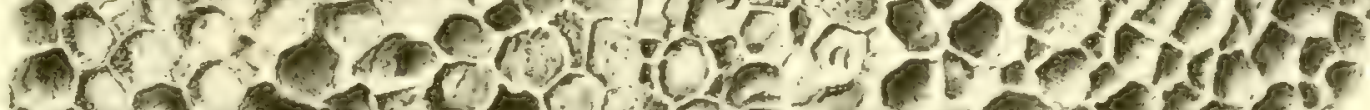

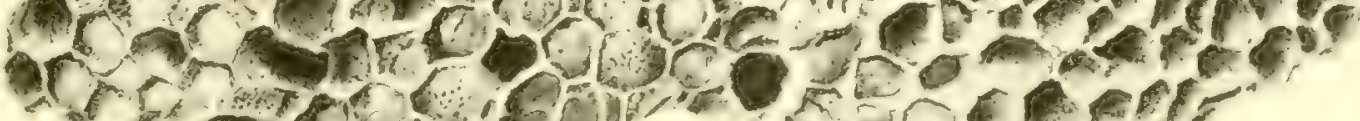

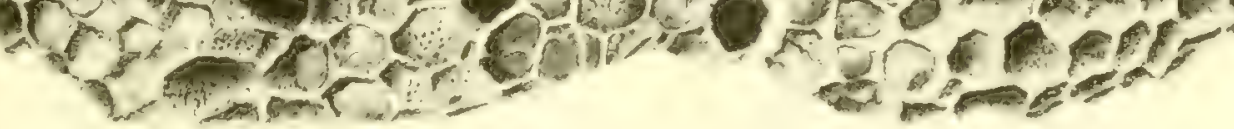





$$
\text { - }
$$




\section{PLAT'T XVII.}

\section{Mímelika Clappi.}

Chonostegetes Clappi Fdw.-Haime. Polyn. Foss. Terr. Pal., n. 299, pl. 14. figs, 4, 48. 1851.

Compare Wichelina intermitiens Billings. Canad. Joum. New Series, Vol. IV p. 113. 1850

". Haimeophyllum orinatum Billings. Camad. Journ. New Series, Vol. IV, p. 139. 1859.

Emmonsia? cylindrica Edw.-Haime. Polsp. Foss. Terr. Pal., p. "245. 1851.

Fig. 1. The upper side of an irregular subhemispheric mass where the oritices of the cells are somewhat free and apparently circular from the constrictions of the interior. In this condition it may be similar to the form described by Billings, as Michelina intermittens. Some portions of the same specimen show the peculiar characters of Chonostegetes, which are more fully shown in figs. 2 and 3 . The illustration of the rarious phases of this coral will appear in the final publication of the corals in the Palreontology of New York.

Fig. 2. A group of columns from a large mass, showing the constrictions at intervals, with the expansions, like diaphragms, connecting the whole together. These are simply the fillings of the circular constricted cells of specimens similar to the preceding, the coral walls having been dissolved away.

Fig. 3. The ends of the colnmns as shown on the upper side of the preceding specimen. This specimen is from the Picket collection in the State Museum, and probably from the neighturhood of Caledonia in Liringston county.

Salid masses, presenting circular depressions or cell-apertures are common in the Upper Helderberg Limestone, in various parts of New Iork. Ot grinding and polishing these, the augular cell-walls are shown with the circular form within them.

\section{MICHELINA FATOSOIDEA.}

Michelina fatosoidea Billings, ('anad. Journ., New Series, Vol. IV, p. 114. 1859.

Fig. 4. A fragment of a larger mass with open cells and continuous horizontal diaphragms. The pores of the cell-walls are not risible. 

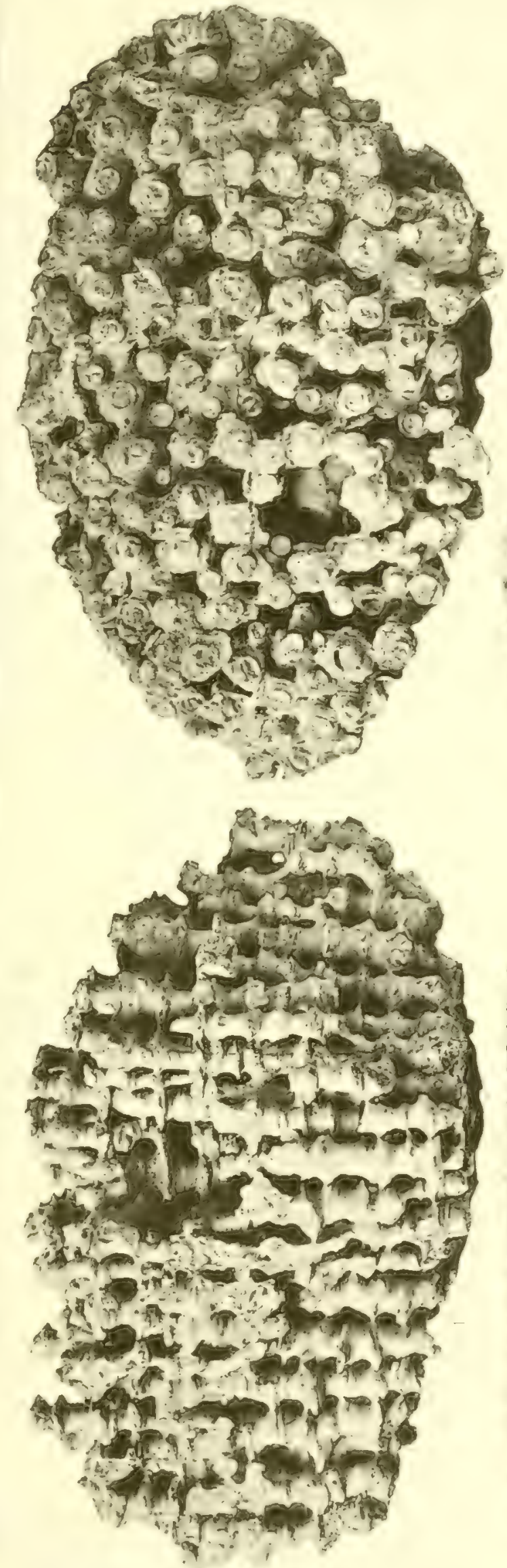


\section{.}

. 



\title{
PLATE XVIII.
}

\section{Michelina (Pleurodictyom) stylopora.}

\author{
Astrea stylopora Faton. Geologicai Text Book, p. 40, pl. 4, f. 48. 1832.
}

Fic. 1. Lateral view of a specimen larger than the ordinary size.

Fin. 2. A summit view of the same individual, showing the striations of the cell-walls. Across the lower part of this specimen there is a line of division indicating the existence of two separate groups or twin germs in the same mass.

Fir. 3. An enlargement of $a$ few of the cells, showing more clearly the crenulated character of the cell margins.

Fig. 4. The base of another individual which has commenced its growth upon the shell of a Loxonema - a very common feature of this species in many localities.

In this individual the calcareous matter of the epitheca and cell-walls has been weathered away, leaving the filling of the pores to show as connecting processes, producing the condition shown in typical specimens of l'leurodictyum, the $P$. problematicum being simply a weathered condition of Michelira. The details of this condition will be shown in the Lithographic plates to be giver hereafter.

Fiw. $\therefore$. View of the base of a smaller individual of similar mode of growth, where the epitheca and celi-walls are preserved.

Fir: i. A lateral view of a specimen of very unusnal form and mode of growth, being spluerical and enclosing a part of a crinoidal column upon which it has growu.

Fin. 7. A vertical section of a large individual, showing the division of cell-walls and the origin of new cells, the irregular and distant diaphragms, which are both convex and concave, and in several places the pores passing through the cell-walls.

lig. 8. A transverse section enlarged, showing the crenulated sides of the cell-walls, caused by the remains of rertical lamelle.

IF. 9. A still farther enlargement of the external surface of the vertical lamellax, as shown in figures 1 and 2 , the surface being fattened and wrinkled.

The specimens are from the Hamilton group, at Darien, York, shore of Lake Erie, and other localities in Western New York.

\section{Micheira (Yleulodictyum) dividua ne spo.}

Fig. 10. Lateral view of a specimen showing the wrinkled epitheca of the exsert indivicual cells.

Fig. 11. Summit view of a larger and very perfect specimen, sliowng the usual size of the cells.

Fig. 12. Lateral view of the same specimen (fig. 11), showing the characteristic form of the epitheca.

Fig. 13. Lateral view of an elevated form where the cells are but slightly divergent.

ligg. 14. Lateral view of another individual, which, although much elongated, does not show the extermal epitheca, the open cells covering all parts of the surface. The colony has been epiphytic on a convex bivalve shell.

Fi:r. 15. A vertical section of a broad flattened specimen.

Fir. 16. A similar view of a more elevated or upright growing form. Both the specimens show the closely crowded diaphragms and the large pores.

Fir. 17. A transwerse section of a broad specimen. The figure does not show the crenulations on the sides of the walls covered by the striæ, which in the example are very fine and numerous. 

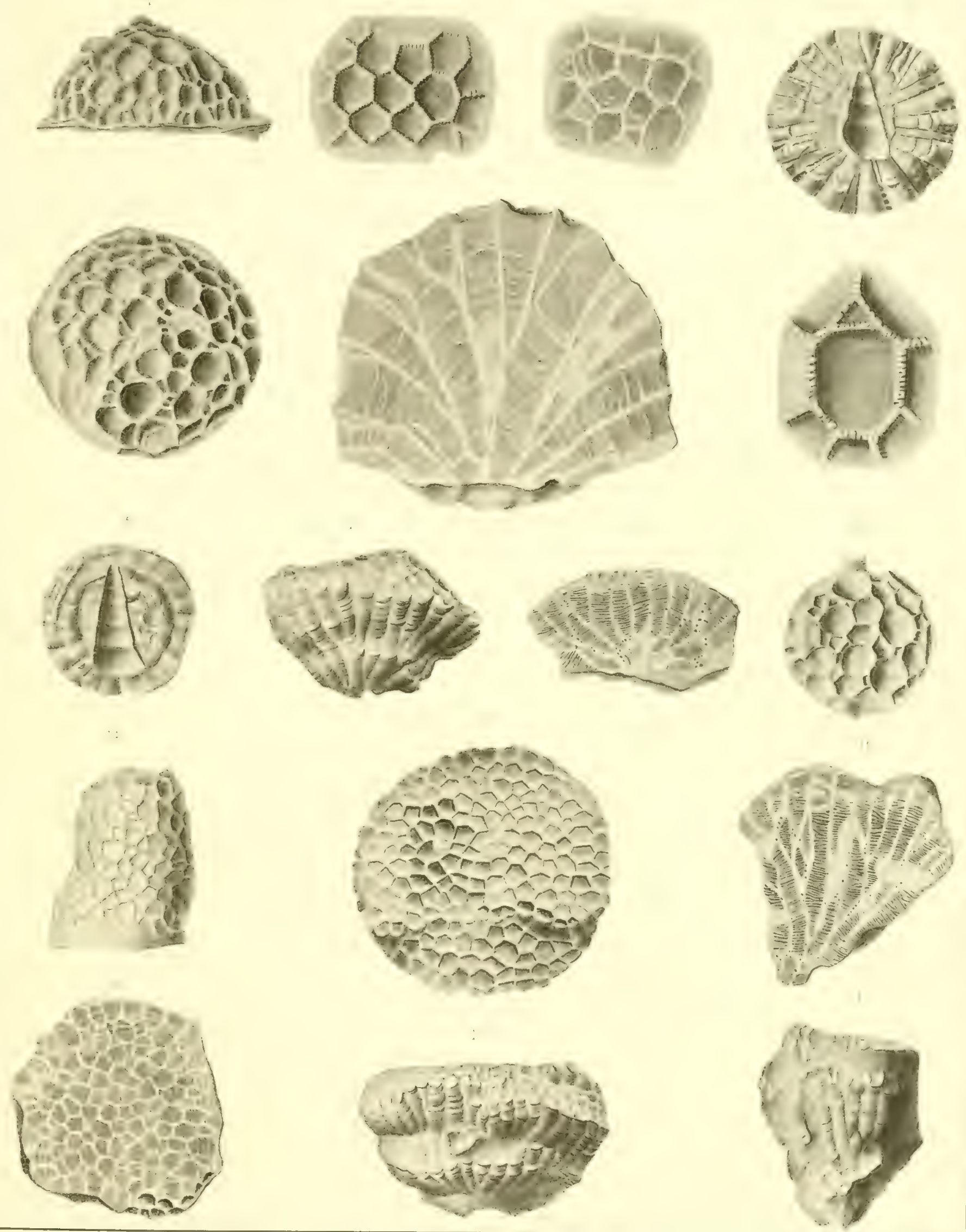




\section{P'LATE XIX.}

\section{STREPTELASMA IBECTA.}

Strombodes? rectue Hall. Geology of N. Y. Surv. Fourth Geolog. Dist., pp. 209, :10. 1813.

Cyathophylum rectun Edw. - Haime. Polyp. Foss. des 'Ferr. Palreozoiques. 1851.

Figs, 1, 2. Lateral views of specimens of usual size and form, when not compressed.

Fig. 3. View of a large specimen, showing the continuous line of the primary lamella of the fosset, and the increase of the lamellæe on each side.

Fig. 4. Lateral view of a specimen, showing the parallel strix, indicating the lamella between two of the primaries.

Fig. 5. Longitudinal section of a small specimen.

Fig. 6. Longitudinal section of a larger specimen, showing the edges of the lamella in the middle, and the sides of others toward the margin, with slight indications of tiansverse lines.

Fig. 7. Lateral view of a curved specimen, showing a budding grow th above.

Fig. 8. Enlargement of a portion of the exterior; on a line with one of the primary lamella, showing the increase to be on one side. This is frequently the case with the lateral primary lamellie.

Fig. 9. View of an unusnally broad specimen.

Fig. 10. An enlarged transwerse section, just below the bottom of the cup, slowing the extension of the primary lamelle to the center, and also the sparsely distributed interlameilar cistose plates.

Fig. 11. An enlargement of a section lower down upon the coral, showing the thickening of the lamelix forming a solid central callus. This thickening is often continued till the lower part of the coral has become solid.

Fig. 12. An enlargement of the interior of a cup, showing the curving of the lamella and the deen fosset extending towards one side.

Figr. 13. Tiew of a specimen from which the margin of the cup lias been broken.

Hamilton group, from various localities in Western New York.

\section{Streptelasma tigula 11. Sp).}

Figs. 14, 15. Right and left lateral riews of two specimens, showing the increase of septal lines.

Fig. 16. Dorso-lateral view of another specimen.

Fig. 17. Longitudinal secticn, showing the thickened, almost solidifed lamelli.

Fig. 18. The concave side of a specimen of irregular growth, partially showing the characters of the cup.

Fig. 19. View of another specinen, showing irregularities of growth.

Fig. 24. An enlarged transverse section, just below the base of the cun, showing the fosset on the right side.

\section{Amplexus HaMLTONiæ n. sp.}

Figs. 20, 22. Lateral views of specimens of different forms.

Fig. 21. View of the largest specimen yet observed; the upper part occupied by the cup is flattened and much broken.

Fig. 23. Longitudinal section, showing the thin walls and broad transverse diaphragms, extending quite across the cup, which is comparatively destitute of radiating lamella.

From the Hamilton group. 

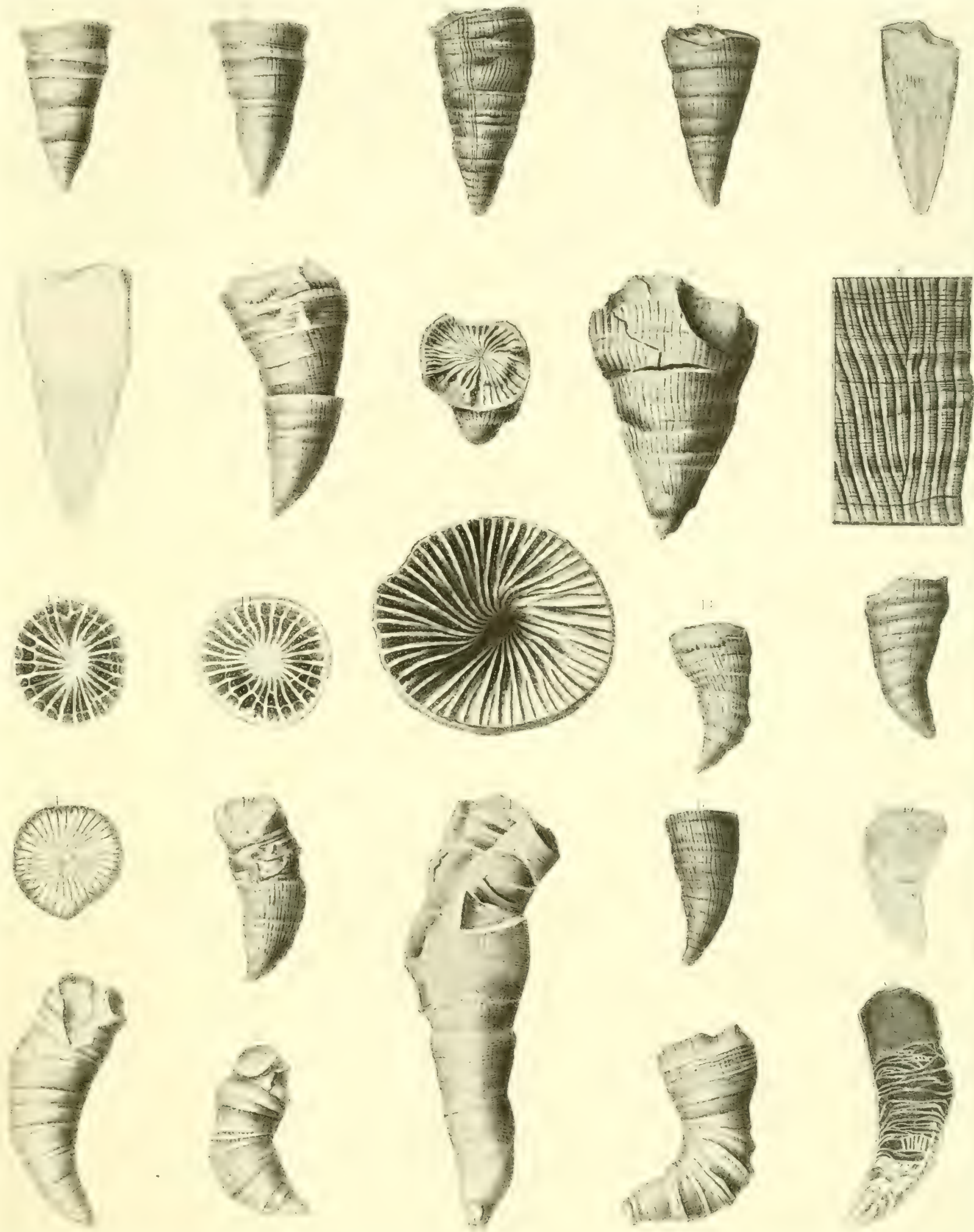



\section{P'JATE XX. \\ Zaphrexts Haldi.}

Zaphrentis Halli Edw. - Haime. Polyp. Foss. des Terrains Palæoznques, 1. 341. 1851.

Fig. 1. A transwerse section across the lower part of a specimen showing the broad diaphragtns, the lateral fosset, and also the extent of the lamellie.

1..r. :2. View of the broad shallow cup of a small specimen, having the fosset on the right sicie.

Fi.. 3. A short broad form, with a deep cup and external fosset. The specimen has a broad expauded foot-like base, by which it has been attached to some foreign body.

The specimen is referred to this species with some cloubt of its positive identity.

Fig. 4. The interior of the cup of another specimen, an inch and a quarter in depth, the fosset external.

Fu. 5. Transverse section of a large specimen, showing the extent of the lamellw and the interlameliar partitions, as well as the broad transverse diaphragms.

Fise. 4. Lateral view of a large specimen, with deep, narrow cup. A part of the rim has been broken off.

F. T. Lateral view of a shorter and broader form than the preceding.

lin. S. A longitudinal section, showing the crowded transverse diaphragms.

F... 9. The interior of the cup of a medium sized specimen.

Hamilton group, Skaneateles Lake and vicinity. 



\section{PLATE XXI.}

\section{ZAPMRENTIS AMPLA H. SP.}

Fig. 1. The interior of the cup of a large specimen, showing an obliquely placed fosset. Hamilton group, Darien, N. Y.

Fig. 2. The calyx of a smaller specimen, where the rays are obsolete on a part of the transverse plate. The fosset is situated, as in the preceding specimen, but rery indistinct. Hamilton group, York, Livingston county, N. Y.

Fin. 3. Lateral view of the specimen fig. 2 .

Fig. 4. Lateral view of a large specimen of similar form with the preceding.

This species is placed by Dr. Roninger with Zaphrentis prolifica of Billings.

\section{ZAPHRENTIS SIMPLEX.}

Strombodes simplex IIall. Geology of N. Y. Surr. Fourth Geolug. Dist., pp. 209, 210, fig. 6. 1813.

Fig. 5. Posterior view of a specimen of usual form, showing the cup with rays extending to the center. Moscow, N. Y.

Fig. 6. View of a specimen showing a broat transverse plate destitute of rays.

Fig. 7. Lateral view of the same, showing the general form of the coral.

Fig. 8. Transverse section just below the bottom of the cup. This is the original specimen of the species.

Fig. 9. Longitudinal section of a specimen, slowing closely crowded transverse plates, some of which have rays extending nearly to the center, and others destitute of rays.

Fig. 10. Longitudinal section of another individual with more distant transverse plates.

Fị. 11. Lateral view of a specimen, exhibiting unusual characters of the cup, corresponding more nearly to those of $Z$. Halli, and referred witl donbt to this species. From near Moscow, N. Y. 


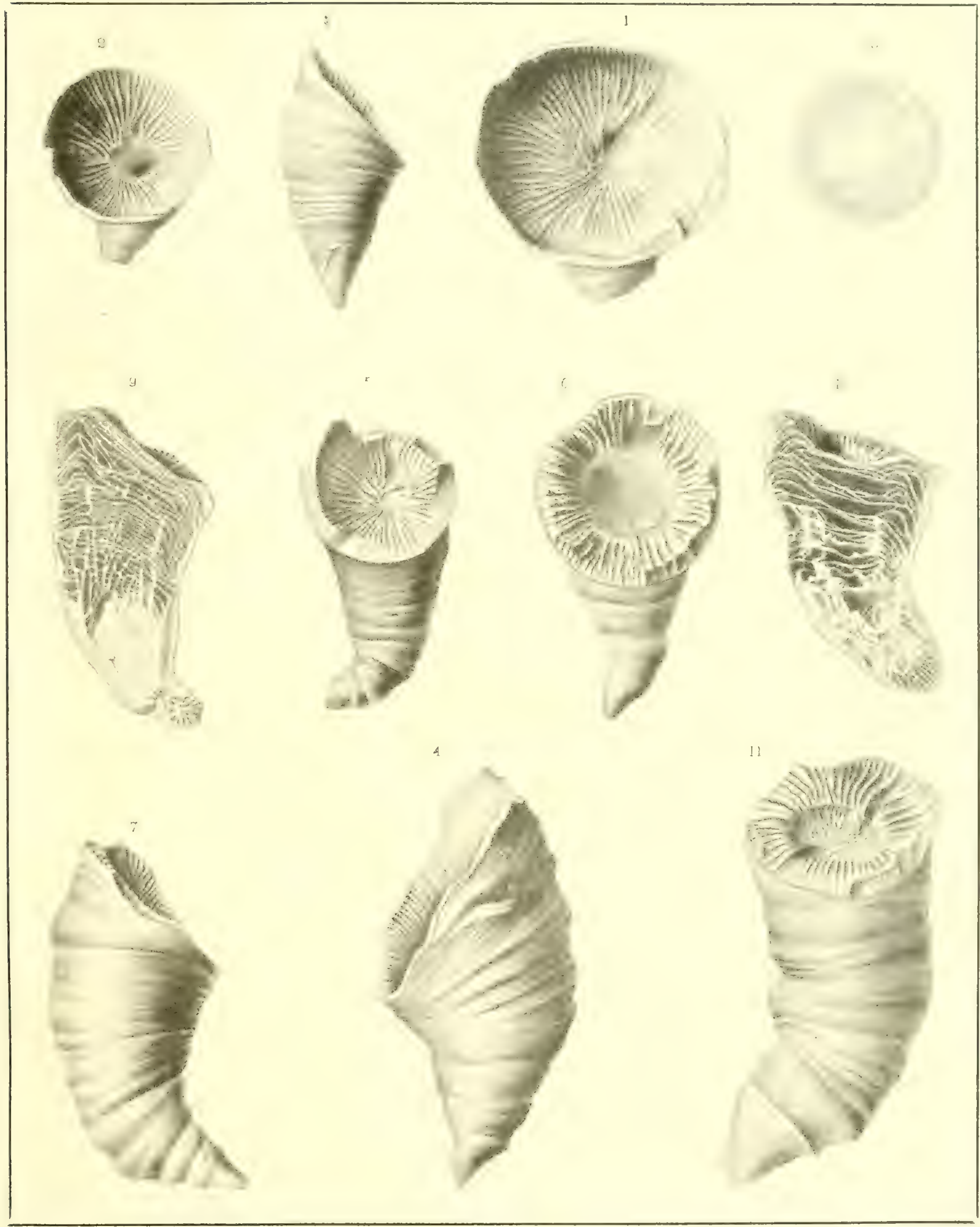

G. B. Bxmpoon delo 



\section{PIJATE XXII.}

\section{CyathophyluU robustum n. $\mathrm{sp}$.}

Figs. 1, 2. Lateral view and interior of the cup of a young individual.

Fig. 3. Lateral view of a very large specimen, showing irregular growth.

Iig. 4. Tiew of the cup of the preceding specimen.

Fif. 5. Transverse section near the middle of specimen fig. 3.

Fy. 6. An enlargement of a portion of the sume section, to show more distinctly the character of the interradial vesicular plates.

Fig. 7 . Interior of the cup of a smaller specinen.

Fig. 8. Iateral riew of the same, showing the curvature.

Fig. 9. Longitudinal section of a similar specimen, showing the depth of the cup and the character of the interradial vesicular plates.

Fig. 14. An enlargement from the surface of specimen fig. 2, showing the radiating lamellæ and the form of the interradial resicles.

These specimens are all from the Hamilton group of Western New York.

\section{Cyathophylü repos 11. sp.}

Figs. 10, 11. Lateral view and interior of the cup of a specimen of the species. From the Hamilton group, Livingston county, N. T.

\section{Cyathophillum Nanum 1. sp.}

Figs. 12 and 13. Two views of a specimen, showing the character of the surface and form of the corallum. Hamilton group, Moscow, N. Y.

The interior of the calyx is illustrated on plate xxxi, fig. 14. 


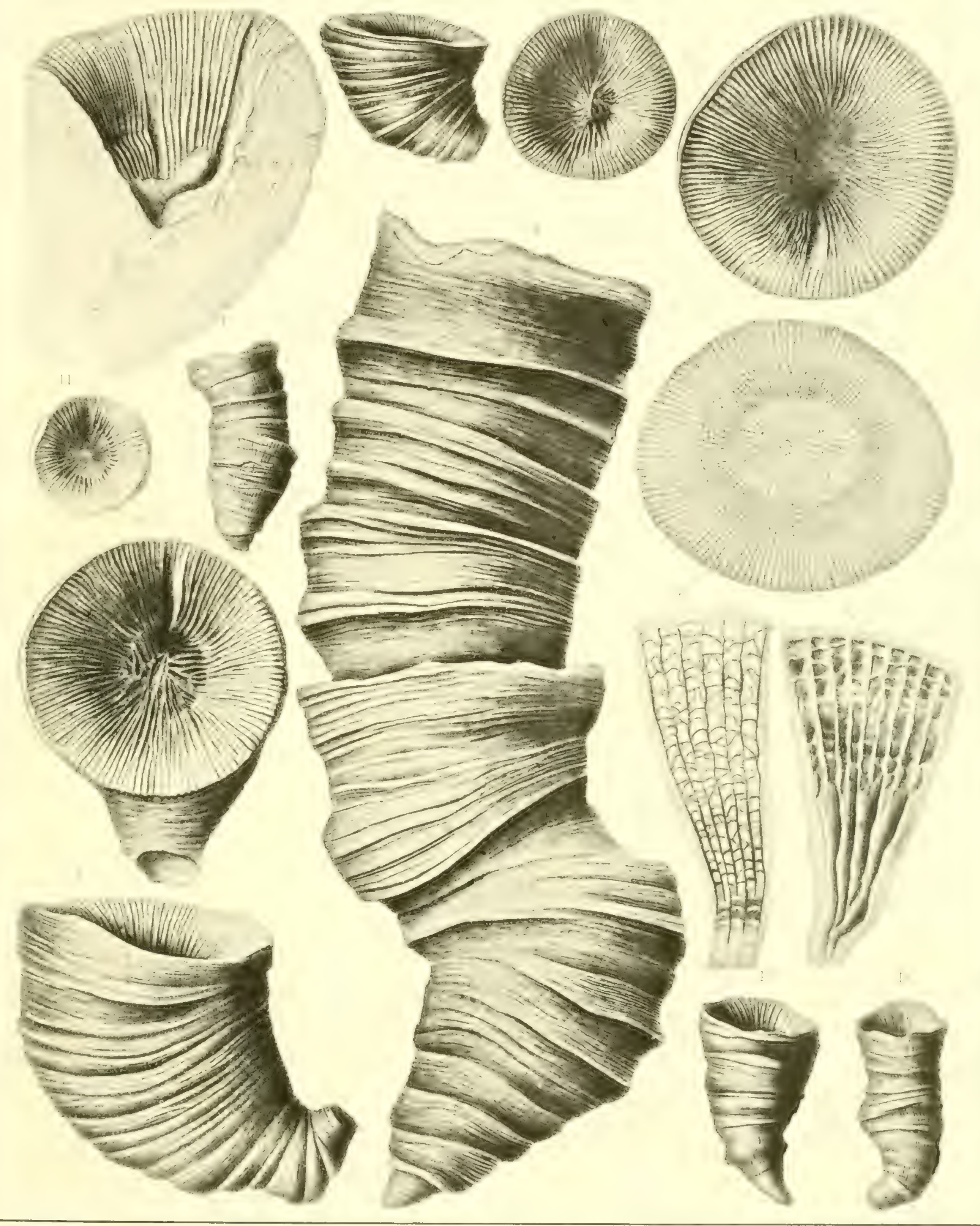






\section{PLATE XXIII.}

\section{HeLtophyLuM HaLLI.}

Strombodes helionthoiles (Goldf.) Hall. Geology of N. Y. Surv. Fourth Geolog. Dist. p. 309, f. 3. 1843. Heliophyllum Halli Edr. and Haime. British Foss. Corals, iutrod. p. lxix. 1850.

Polyp. Foss. des Terr. Palacuzoiques, p. 408, pl. $\%$, fig. 6. 1851.

Figs. 1-3. Views of three specimens differing in form of corallum and depth and size of cup.

Fig. 4. Longitudinal section, showing the depth of cup and interior structure.

Fig. 5. Transverse section of a similar form.

Fig. 12. An enlargement of a section of the specimen Fig. 5, showing the transwerse ridges of the lamellie and the interradial vesicular plates.

Hamilton group, in numerous localities in Western New York.

\section{Heitopit lidu Halis var, ReFlexum.}

Fig. 6. Lateral view of a young specimen, showing the reflexed cell-margins and distant lamellw, with a comparatively small and shallow depression.

Fig. 7. A similar view of a larger individual.

Figs. 8-10. Three views of a large specimen, having the top somewhat more flattened.

Fig. 11. An enlargement from the surface of the same, sliowing the projecting transverse ridges and the interradial resicular plates.

Hamilton group, Livingston county, New York. 


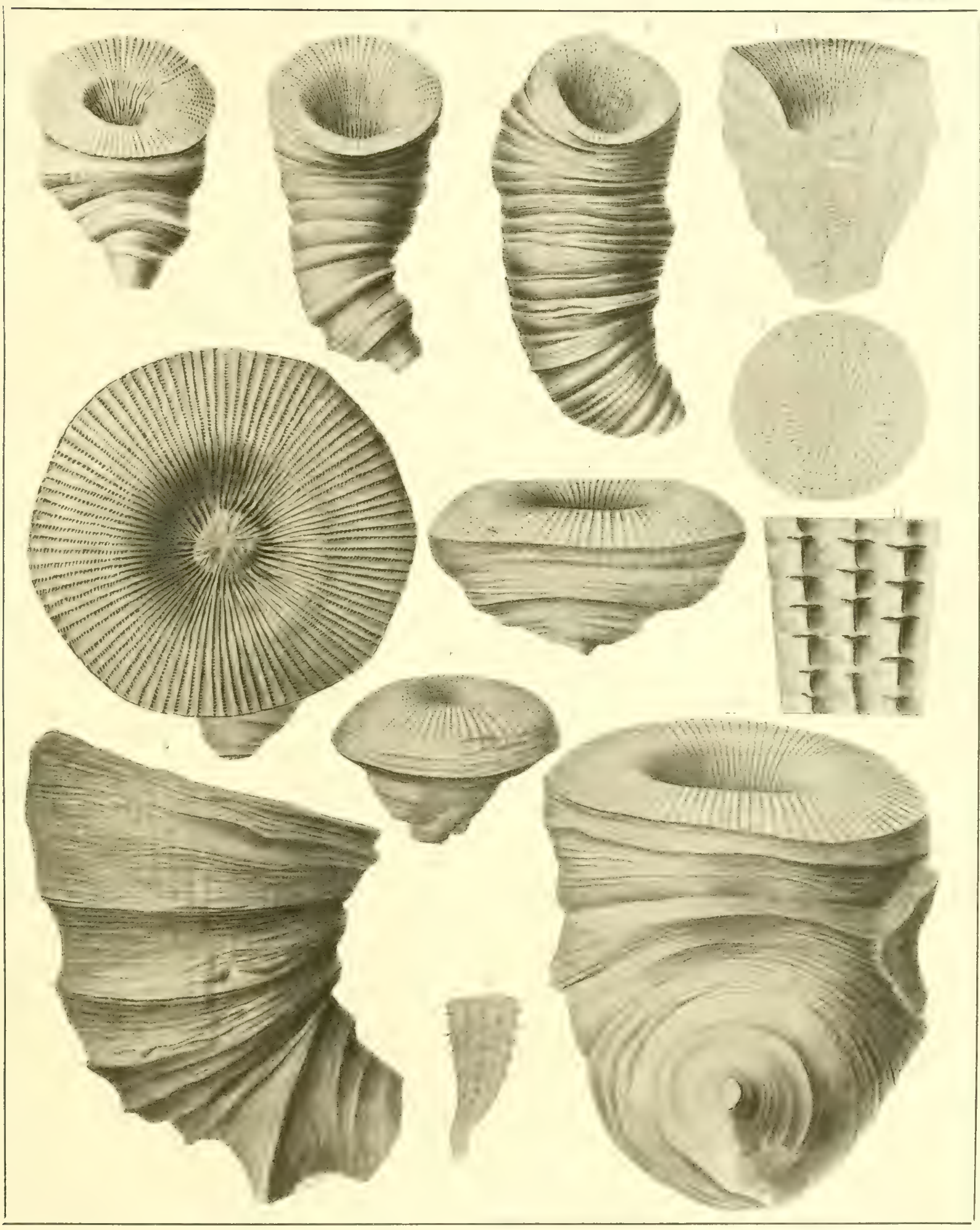






\section{PLATE XXIV.}

\section{HELIOPHYLLUM IRREGULARE n. sp.}

Figs. 1, 2. Lateral and summit views of a small specimen, showing very distant lamella and a flattened surface outside of the depression.

Figs. 3, 4. Two views of a specimen in which the rays are a little more numerous.

Fig. 5. Enlarged profile of a primary and a secondary "ray of the preceding specimen, showing the form of the cup and the projecting denticles formed by the transverse ridges.

Fig. 6. View of a more spreading young specimen.

Fig. 7 . View of a large specimen, showing a bulding from the center of the cup.

Hamilton group, Darien, and other localities of Western New York.

Fig. 13. Transverse section of a specimen simular to Fig. 7.

\section{HELIOPHYLLUM ARACHNE n. sp.}

Figs, 8, 9. Two views of a specimen, showing the form of the corallum, the convex surface, shallow cup and distant rays, with strongly elevated denticles representing the transverse ridges.

Figs. 10-12. Three views of another individual in which the transverse bars are nearly obsolete on some parts of the corallum. Figs. 11 and 12 show the irregular projecting root-like base of attachment.

Fig. 14. Profile of a primary and secondary ray from the specimen Fig. 8 , showing the form of the cup and the projecting denticles. 


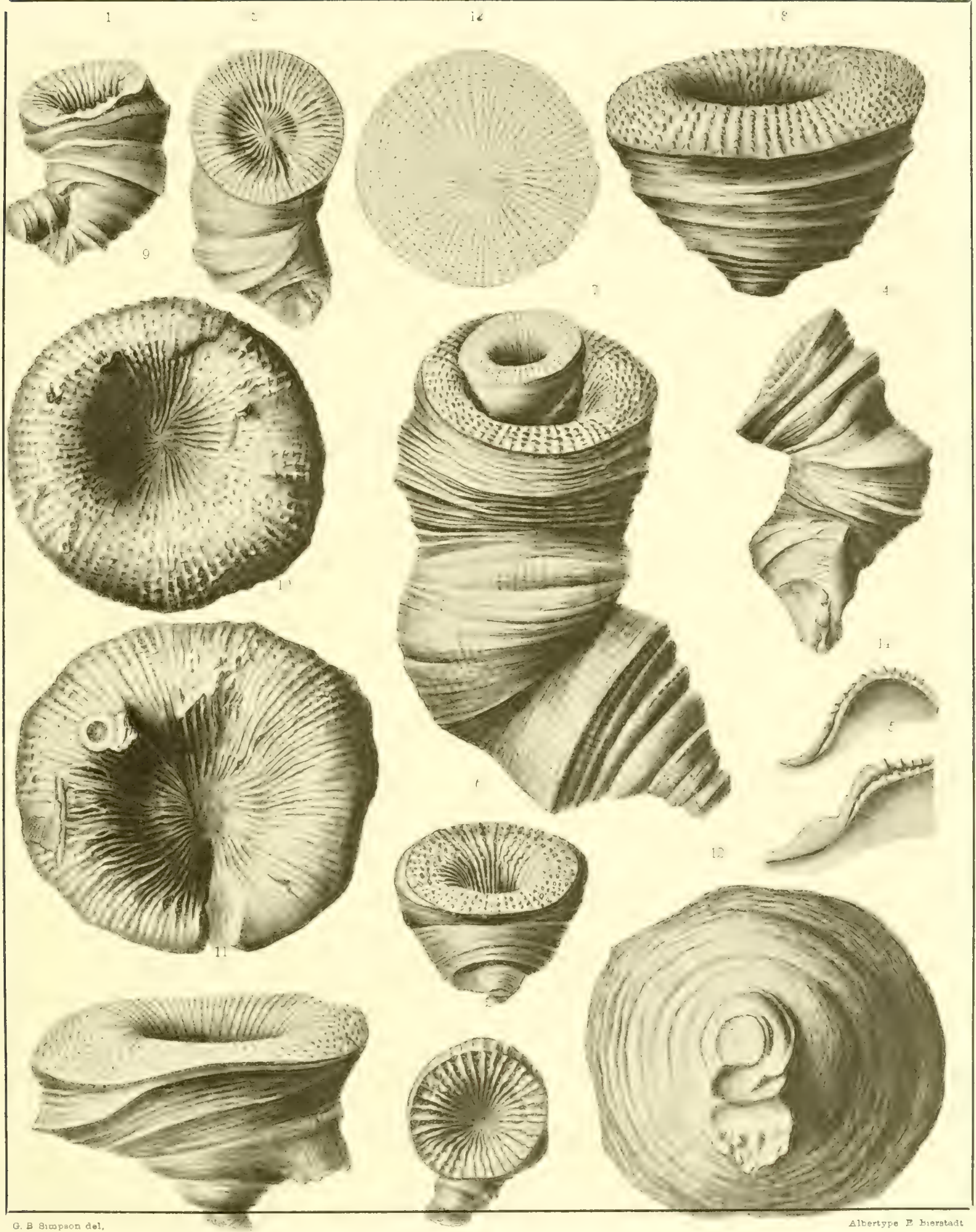





\section{PLATE XXV. \\ HeLiopirlutu HALII.}

(See Plate :

Fig. 1. Ve:tical section from near the outer surface, greatly enlarged.

Figs. 2, 5, 7. Fig. 7 , represents a transverse section, natural size. Fig. 5, a portion of the same enlarged. Fig. 2, a still further enlargement, showing the rays, the transverse ridges and the interradial plates.

Hirs. 3, 6. Fig. 6 represents a transverse section with very closely arranged transverse dissepiments. Fig. 3 an enlargement of another portion of the same specimen.

Fig. 4. A further enlargement from the specimen Fig. 12, Plate 23, showing the thickening of the rays and transverse dissepiments, and the more irregular form of the interradial vesicles. This and fig. 1 are referred. with some doubt, to this species.

\section{HELIOPHYLLUM DEGENER $\mathrm{n}$. sp?}

Irigs. 8, 9. Two views of a specimen which is strongly contracted towards the upper part, and the surface destitute of epithecn.

Figs. 10, 11. Two views of a smaller specimen, showing a broader cup but similar surface. Hamilton group, Skaneateles Lake, N. Y.

\section{HELIOPHYLLCY HALLI? VAr, OBCONICUM.}

I:ys, 12, 12. Views of the opposite siles of a specimen, showing the regular turbinate form and distant lamellar ridges of the surface. Hamilton group, Skaneateles Lake, N. Y. 


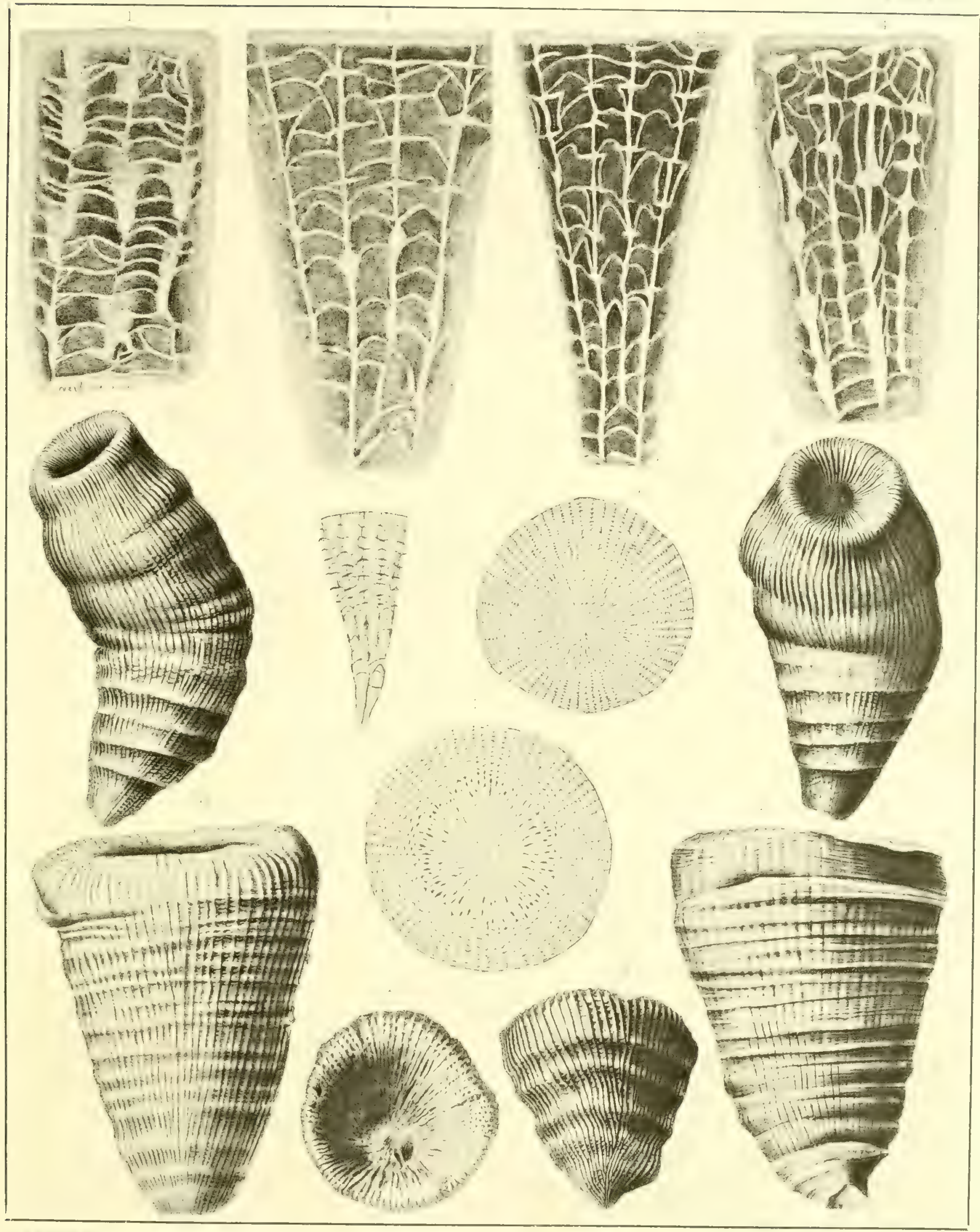


. 



\section{PLATE XXVI.}

\section{HELTOPHYLLUM PROLIFERUM 11. Sp?.}

Fig. 1. View of the upper side of a group, showing buds in various degrees of derelopment.

Fig. 2, The opposite side of the same specimen, showing the origin of some of the buds, which rise from the sides of the principal stem.

Hamilton group, Darien, N. Y.

\section{HELIOPH YLLUM CONFLUENS n. sp.}

Fig. 3. View of the under surface of a small specimen, showing several buds united.

Fig. 4. Upper surface of the same specimen, slowing the calyces irregularly united. Hamilton group.

\section{HeLIOPHYLLUM PROLIFERUM?}

Fig. 5. Oblique lateral view of a specimen, showing irregular budding in different stages of growth originating from the calyx of the parent coral. Hamilton group, Livingston county, N. Y. 


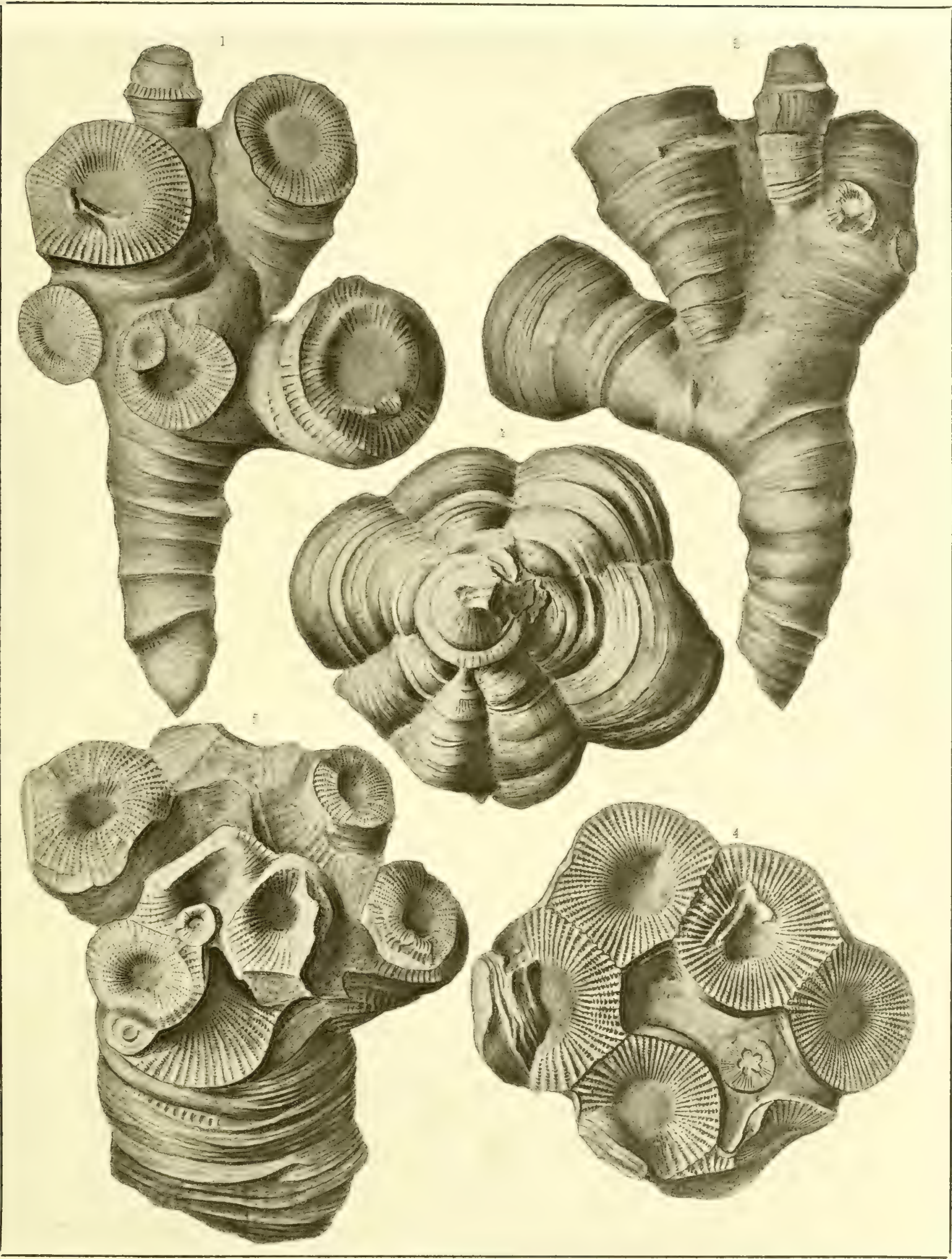


. 


\section{PLATF XXVII.}

HELIOPTYLIUM CONFLUENS 11, Sp.

The upper surface showing the calyces of a colony of individuals growing in a compact cespitose group. Hamilton group, York, Livingston county, N. Y. 


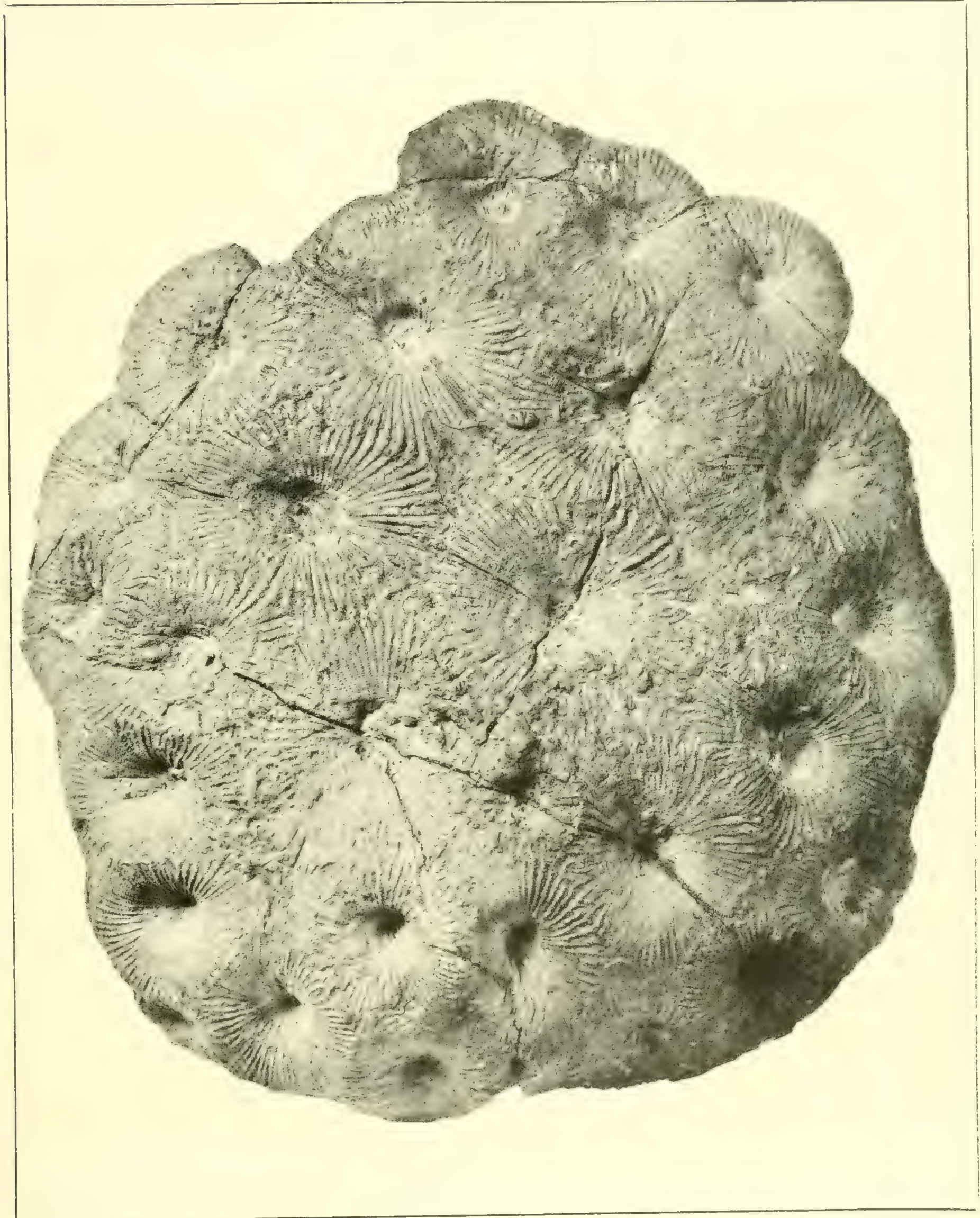





\section{PLA'TE XXVIII.}

\section{Cystiphylum Americanum.}

Cystiphyllum Americamum. Fdwards-Haime. Polyp. Foss. Terr. Palacuzoiques, p. 464, pl. 13, tig. 4.

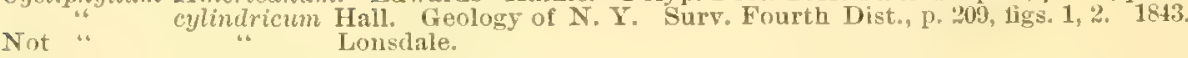

Fie. 1. Lateral view of a medium sized specimen, from which the epitleca has been eroded, ex. posing the cysts over nearly the entire surface. Moscow, New York.

Fin. '. A larger specimen, showing a similar condition, and haviug the cup contracted to about half the size of the body below. T'own of Bosanquet, Ontario.

F.:. :., Longitudinal section of a specimen, showing the cystose structure. Skantateles Lake, New York.

IFig. 4. Lateral view of a twin corallum, the two cells being enclosed by a continuous epitheen. The sudden contraction near the summit is caused by a twin budding of the same character; and from the later division on the right side a distinct and indenendent bual had commenced its growth.

Fir. i. Lateral view of a specimen preserving the external epitheca, and exhibiting an unusual degree of regularity in its mode of growth.

Fin. 1. View of the interior of the cup of the preceding specimen, slowing a slight tendency to lorm rays along the surface of the cysts.

Fin. 7 . Transverse section of a specimen, showing the whole structure to be without rays or concentric rings.

\section{CrstiphylLUM VARIANS.}

(See Plate :29.)

Fiy. 8. Transverse section, showing the cysts arranged in concentric circles, forming cups as in Chonophyllum, and also showing that the incipient rays are developed into continuous lines in the interior. 


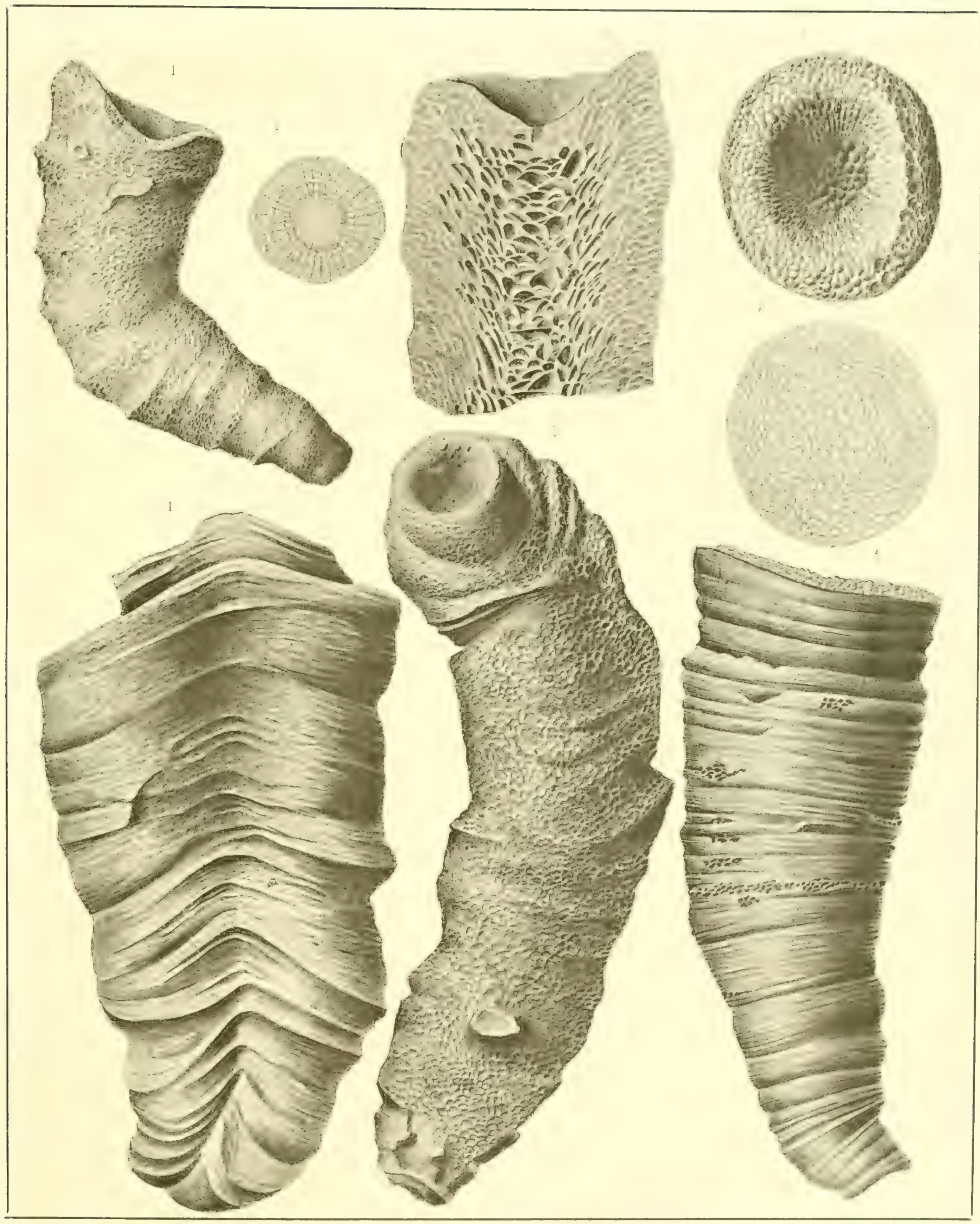





\section{PLATE XXIX. \\ CrstipHYLlum VARIANS n. sp.}

Figs, 1, 2. Lateral view and calys of a small form, the cup showing the incipient rays along the surface of the eysts.

Figs 3, 4. Lateral viww and calyx of a more robust form, the calyx showing the rays somewhat strongly marked. York, Livingston county, N. Y.

Fig. 5. Interior of the cup of a broader form, showing large cysts in the bottom, with incipient rays along the outer part. Moscow, New York.

Fig. 6. View of the calyx of a small specimen, strongly marked with rays on the lower side where no cysts are visible. The specimen had been thrown down while living, and continued to grow until the cup opens in the same direction as the base, or precisely in the opnosite direction from its earlier stages of growth. Moscow, N. Y.

Figs. 7 -9. Lateral, summit and basal views of a rapidly spreading specimen, showing small cysts with strongly developed rays along their surfaces. York, Livingston county, N. Y.

Fig. 10. Laternl yiew of an old specimen, the base of attnchment showing rootlets. Moscow, N. Y.

Tig. 11. View of the opposite side of the preceding specimen; a portion of the coral has been cut away to show the depth of the caly $x$ and the internal structure.

Fig. 12. An enlargement of the upper part of the preceding specimen, showing the obsolescent radii traversing the cysts and also the internal cellulose structure of the corallum.

Fig. 13. A longitudinal section of a specimen, showing the arrangement of the cysts in the form of inverted cones.

\section{CySTIPHYLLUM CORRUGATUM $n$. sp.}

Fig. 14. Lateral view of a large specimen, showing the usual form but slightly compressed. Skaneateles Lake, N. Y.

Fig. 15. Lateral view of a smaller specimen, showing incipient striations on the exterior, and well developed rays along the pustules in the interior of the cup.

Fig. 16. Section of the last, showing the arrangement of the cysts in the form of cups. Skenenteles Lake, N. Y. 


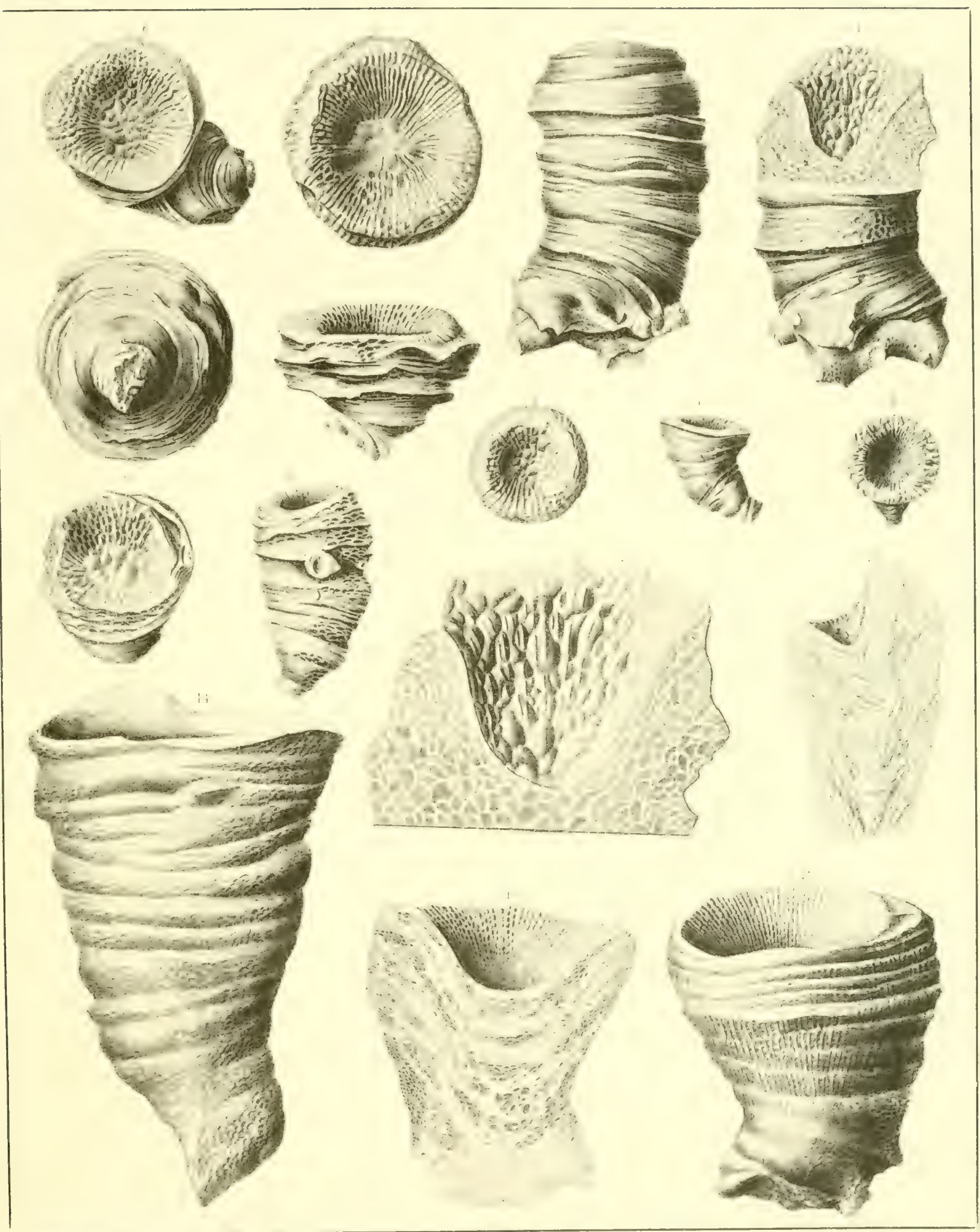





\section{PLATE XXX.}

\section{- Crathophyleum Houghtoni.}

Cyathophyllum Houghtoni Rominger. Geology of Michigau: Palrontology; ined.

Fig. 1. Lateral view of the upper part of a large specimen, showing the cup and the foliated edges of the numerous inverted cones, of which the whole is composed.

Fig. 2. Longitudinal section of the same, showing the depth of the cup and the strongly dereloped rays. The interior carities have all been filled with a calcareors deposit, obscuring much of the structure; but a few of the transverse plates can be traced near the base of the cup, and their edges are seen distinctly for some depth-near the margin of the specircen. Hamilton group, Livingston county, N. Y.

This species presents external characters common to Chonophyllum, and may be regarded as exhibiting a transition to that genus.

\section{CYSTIPHYLLUM CONIFOLLIS 17. Sp.}

Fig. 3. Lateral view of an irregular erect growing specinen of the usual size, preserving the epitheca over nearly the entire surface. Town of Bosanquet, Ontario.

Fig. 4. View of a sia all specimen, from Moscow, N. Y.

Fig. 5. Lateral view of a specimen, preserving the epitheca. The cup is contracted at the summit to less than half the size of the body below. Moscow, N. Y.

Fig. 6. Tiew of a specimen denuded of the epitheca, and showing the vesicular structure over most of the surface. The calyx is contracted above. Moscow, N. Y.

Fig. 7. Longitudinal section of a sinilar specimen, showing the cup-like arrangement of the cysts. Moscow, N. Y.

Figs. 8, 9. Two views, giving opposite sides of a long, slender specimen. One side shows the irregular or intermittent growth, with epitheca; the other side weathered and showing the cup-shaped arrangement of the vesicles. The caly $\mathrm{x}$ at the top is very small and represents the contracted stage of growth. Town of Bosanquet, Ontario.

\section{Cystiphyllum Americanum?}

Fig. 10. A lateral view of a large individual, which is referred with doubt to this species; the cupshaped arrangement of the resicles presenting the features of the preceding form. Hamilton group, Moscow, N. Y. 


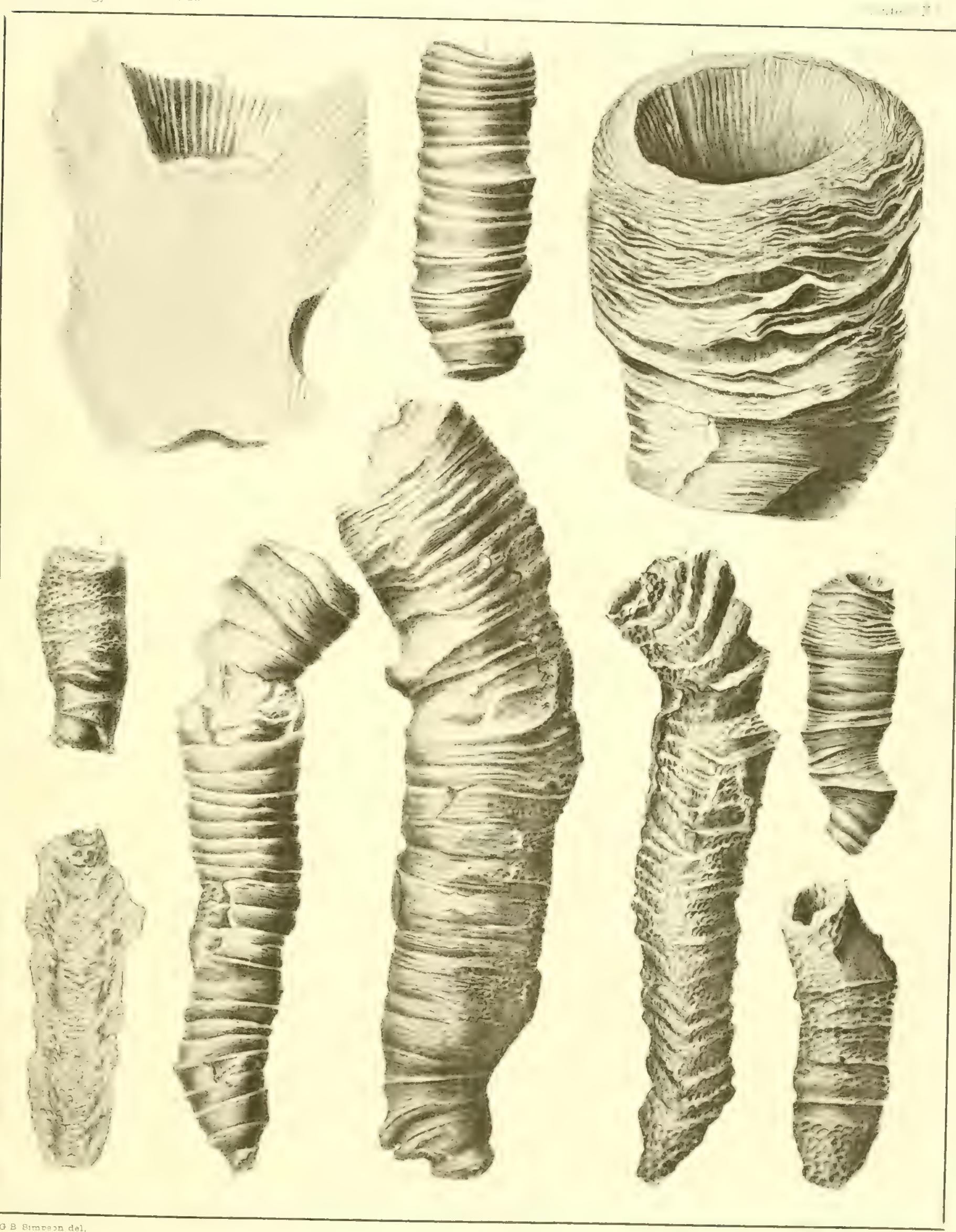





\section{PLATE XXXI.}

\section{Cyathophylum CONATUM n. sp.}

Fig. 1. The exterior of a specimen, showing unnsually regular growth.

Fig. 2. Longitudinal section of the same specimen, showing narrow, much crowded and wrinkled transverse diaphragms.

Figs. 3, 4. Views of the opposite sides of a specimen, showing great irregularity of growth.

Fig. 5. View of a specimen, intermediate in character between the two preceding.

Fig. 6. A small straight specimen of regular growth, with calyx much contracted. This may perhaps prove a distinct species.

Fig. 7 . Lateral view of an imperfect specimen, similar to figures 3 and 4 .

Fig. S. Oblique view of the same specimen, showing the margin of the parent cup, above which the coral is greatly contracted.

Fig. 9. A longitudinal section of a specimen, similar to figures 3 and 7 , showing very broad transverse diaphragms, which are in some parts closely crowded.

Fig. 10. A lateral view of an extremely elongate specimen of very irregular growth.

Figs. 11, 12. Lateral and summit views of a young specimen.

Fig. 13. Enlargement ol the interior of the cup of figure 6. Hamilton group, from various localsties in Tostern New York.

Fig. 14. Tiew of the calyx of Cyathophyllum nanum, plate xxii, figs. 12 and 13 . This figure was omitted by mistake from Plate xxii.

\section{CYATHOPHYLLUI GRADATUM 1. SH.}

Figs. 15, 16. Lateral and sumnit views of a specimen. The opposite side of the specimen is more decorticnted, and presents the aspect of Clonoplyllum, but differs essentially from wery specimen of $C$. conatum.

Crathophylum palua n. sp.

Figs. 17, 18. Trews of the opposite sides of the same specimen. 


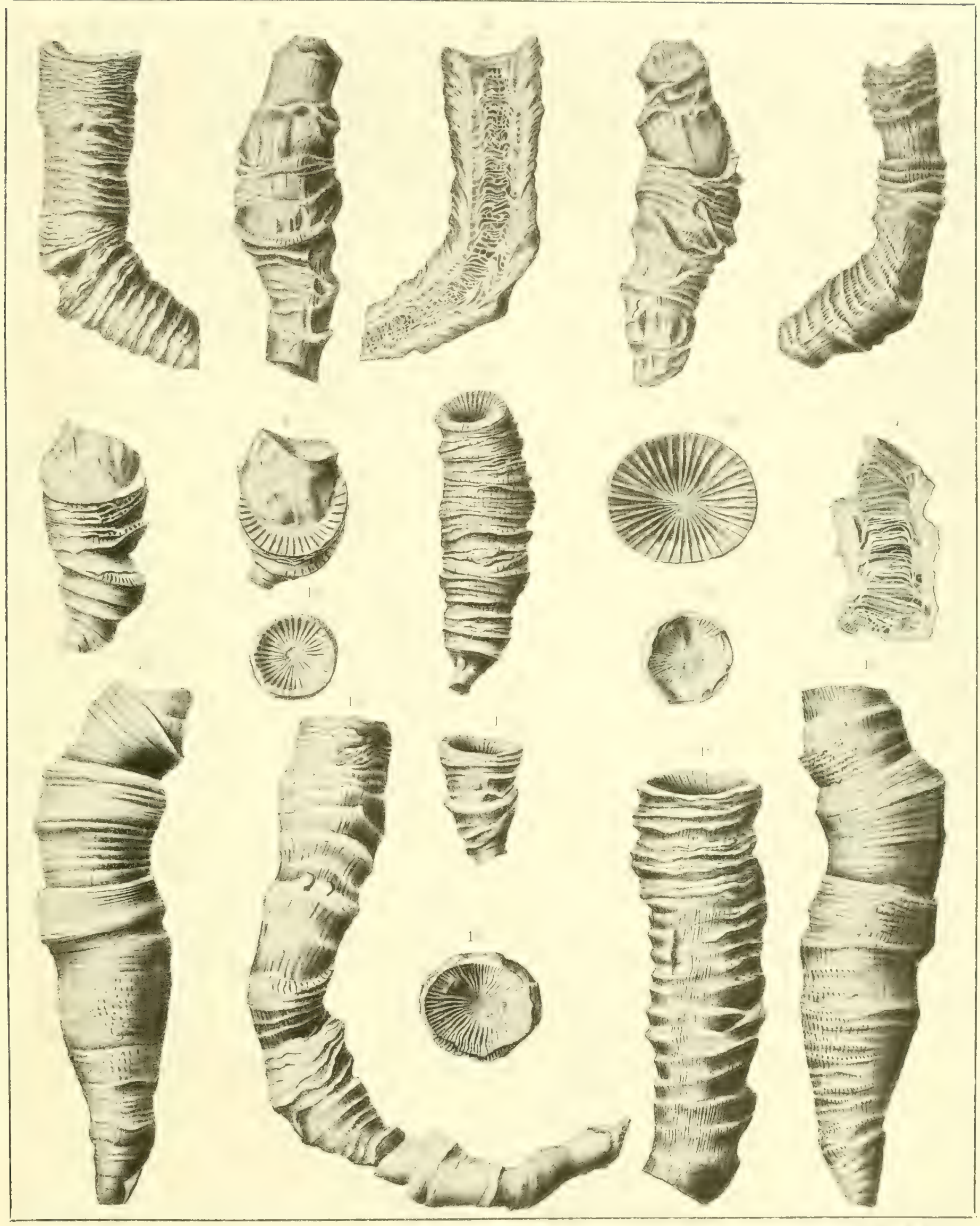



•

- 


\section{PLATE XXXII. \\ Heliophylum (Zaphrentis) exiguUn.}

Hetiophyllum cxigum Billings. Canadiau Jourual, New Series, Vol, V, p. 261, tigs. 8, 9. 1860.

Firs. 1-3. Three views of a specimen of unusual form and size, as found in the Schoharie grit and Upper Helderberg Liruestone of New York.

Fir. 4. An enlargement of a portion of the outer rim and side of a cup, showing the character of the lamellæ.

\section{HeliophyluU? EXIGUUM var.}

Fin. 5. Posterior view obliquely into the cup of the specimen.

Fig. 6. Lateral view of the same.

Fi.. 7. An enlargement of the cun of the same specimen. The great depth is not apparent in the figure, nor the strong denticulations of the lamellæ. Upper Helderberg Limestone of Western New York.

\section{AMPLEXUS INTERMITTENS n. sp.}

Stromboules sp? Hall. Geol. of N. Y. Surv. Fourth Dist. Tables of organic remains, No. 49, fig. 2, 2 a.

Figs. 8-13. Views of a series of specimens exhibiting the usual form and character of the species,

Figr. 14. Lateral view of an elongate specimen, probably of this species.

Fig. 15. Longitudinal section of the preceding specimen, showing the interior to be occupied by irregular and distant transverse plates, with no indication of resicular substance. In the soft shale of the Hamilton group, at Moscow and elsewhere, in Western New York.

\section{C'ystiphyllui (ChONOPIYLLUM) SULCATUM.}

Cystiplyilum sulcutum Billings. Canadian Journal, New Series, Vol. IV, ]. 136. 18.59.

Fig. 16. Interior of a cup of a well preserved specinen, showing the obsolescent rays and fosset.

Fig. 17. Profile view of the preceding specimen.

Fig. 18. View of the anterior side of a specimen where the outer portion has been broken, exposing the diaphragms or cups with their rudimentary rays, and showing the position of the fosset. In this condition the fossil presents more nearly the characters of Chonophyllum.

Fic. 19. Interior of a small cup showing the rays.

Fig. 20. Profile of the same. Upper Helderberg Limestone, near Clarence, N. Y.

\section{CYATHOPHYLLUM GALERUM 11 . Sp.}

Fig. 21. The interior of a cup of a very perfect specimen.

Fig. 22. The convex face of the same, showing the line of the primary ray.

Fig. 23. Lateral view of the same specimen, slowing near the lower part one of the lateral primary rays. Hamilton group, Moscuw, N. Y. 


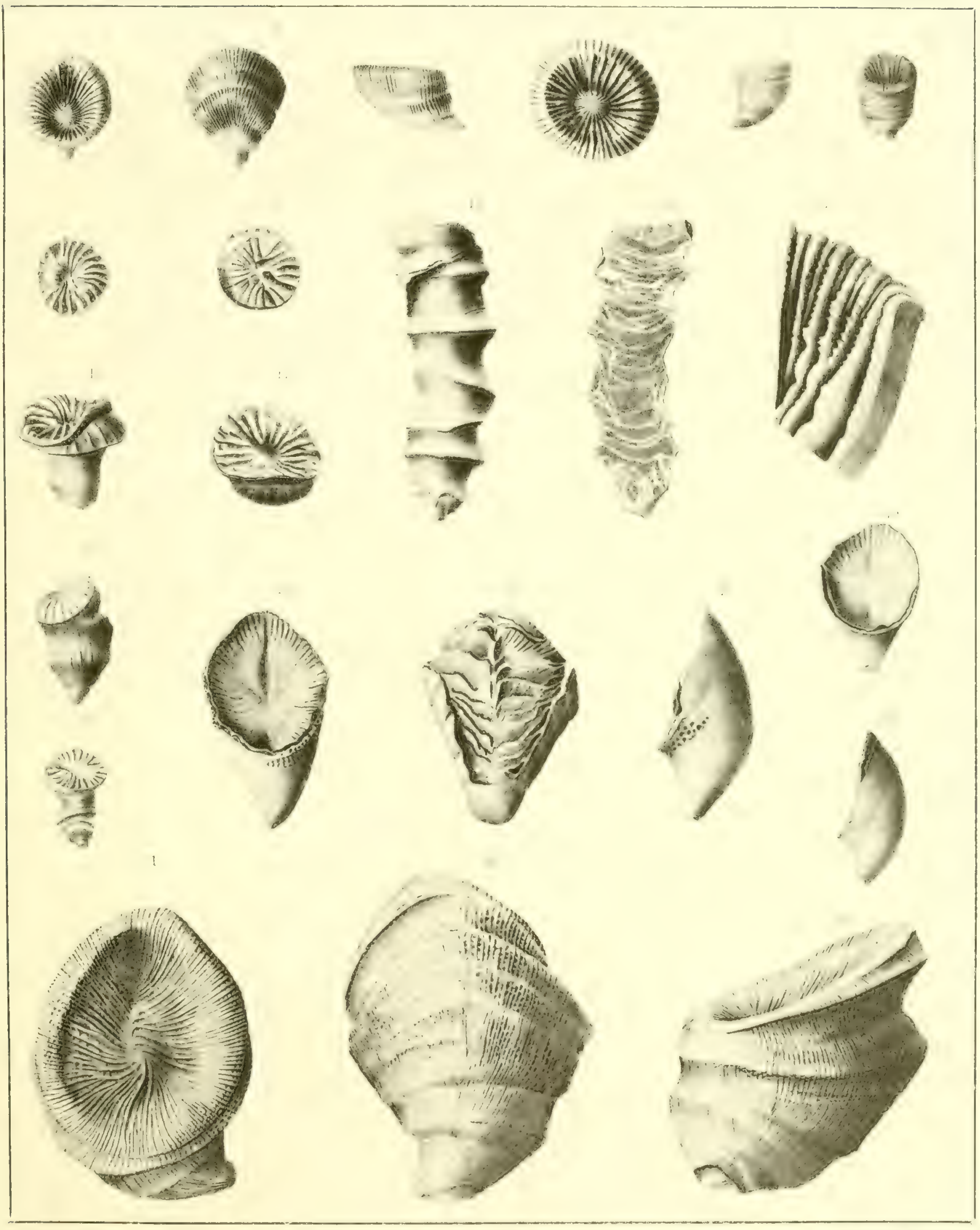





\section{PLA'I'E XXXIII. \\ I'RACHYPORA ELEGANTULA.}

Trachyporu eleguntulu Billings. Cauad. Jouru., New Series, Vol, V, p. 25s. May, 1860

Fig. 1. The upper portion of a sinall branch, showing the ruws of cells.

Fi... "2. A bifurcating fragment of a larger brancl, showing seattered cells.

Fig. 3. A branch somewhat larger than the orlinary size, showing an irregularity in the arrangement of the cells.

Fis. 4. In enlargement of a fragment, with very small cells, which have a spiral arrangement.

Fi... 5. An enlargement from a specimen with large cells arranged in vertical rows.

Fi_. 6. An enlargement of a fragment having large cells with margins unusually prominent and the interspaces stronoly striate.

F._. 7. Longitudinal section of a specimen, with cells of medium size arranged in vertical rows. This section shows the cells communicating with a central longitudinal canal, and divided transversely by thickened diapluragms.

Fi.. 8. An enlargenent of a fragment with cells of medium size, longitudinally arranged, with finely granulose interspaces. Hamilton group, Darien and other places in Western New York.

STRIATOPORA (THAMYOPTYCHLA) LIMBATA.

Madrepora limbata Eitton. Genlogical Text Book, p. 39, pl. 5, fig. 5\%. 183:.

Fin. 9. A large ramose fragment, showing the form, mode of growth and distribution of pores.

Fig. 10. An enlargement of the surface, showing the structure between the cells. (The figure does not filly express the characters.)

Firg. II. An enlargement of a bifurcation, showing the distribution of the stria around the margins, but not entering the cells as in ordinary forms of the genus Striatopora.

F. . 12. Longitudinal section of a branch, showing the oligin and abrupt deflection of the cells: toward the external surface. There is no appearance of continuons transwerse partitions, but the inner surface is corered with projecting spinules nointing toward the aperture.

Fig. 13. Transverse section greatly enlarged, showing the unequal density of the substance between the cells, the spines of the cells, and the cluster of vertical cell-bases in the center before becoming deflected. Haniltun group, Darien and westward to Lake Erie.

The specimen figured by Eaton was from the shore of Lake Erie, at Eighteen-mile creek. 


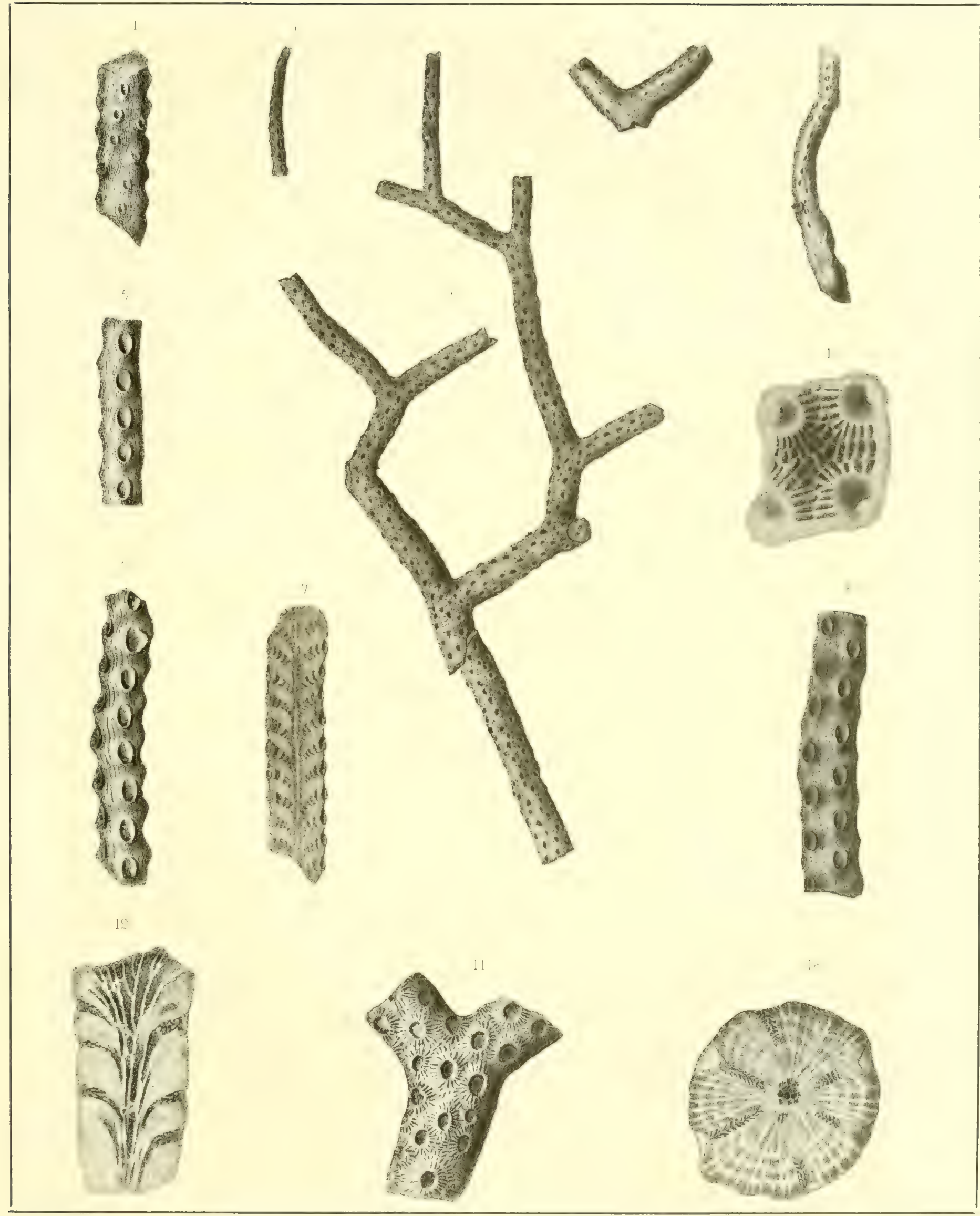

2. B, simpoon, del 
. 


\section{PLATE XXXIV.}

\section{Favosites Hahiltonie n. sp.}

This species occurs abundantly in the calcareous beds of the Hamilton group in Western New Fork, and especially on the shore of Lake Erie. It differs from the F. Billingsi of Rominger in its smaller cells, and other characters. Among the forms here embraced under the same designation, there are considerable differences, which are not regarded as of specific importance.

Fig. 1. The upper fractured surface, showing the open cells and continuous diaphragms.

Fig. 2. A lateral view of the preceding specimen, where the cells are partially free from stony matter, and preserving the continuous diaphragms.

Fig. 3. A fragment of a larger mass, showing a rertical section, with an oblique view of the cellopenings unon the upper surface. The cell-walls are finely striate, but the pores are indistinctly visible,

Fig. 4. A fragment of another specimen where the mural pores are well shown.

Fig. 5. A vertical section from a smaller hemispheric mass, from a polished surface.

Fig. 6. An enlargement of the colunus with mural pores from the specimen fig. 3 .

Fig. 7. An enlargement similar to the preceding from the specimen fig. 4.

Fig. 8. An enlargement of the cells from the upper side, slowing the depressions of the diaphragms at the angles.

Fig. 9. An enlargement of the cells from the upper side of another specimen, showing some of the diaphragms to be plain and flat, and others to be bent downward at the angles.

\section{FAFOSITES PLACENTA.}

\section{(See Plate 35.)}

Fig. 10. A section of a hemispheric form referred with doubt to $F$. placenta. The figure is eularged to two diameters.

Fig. 11. An enlargement of a similar section from a small spheroidal form of the same species. The diaphragms are rarely continuous in either of the specimens. 

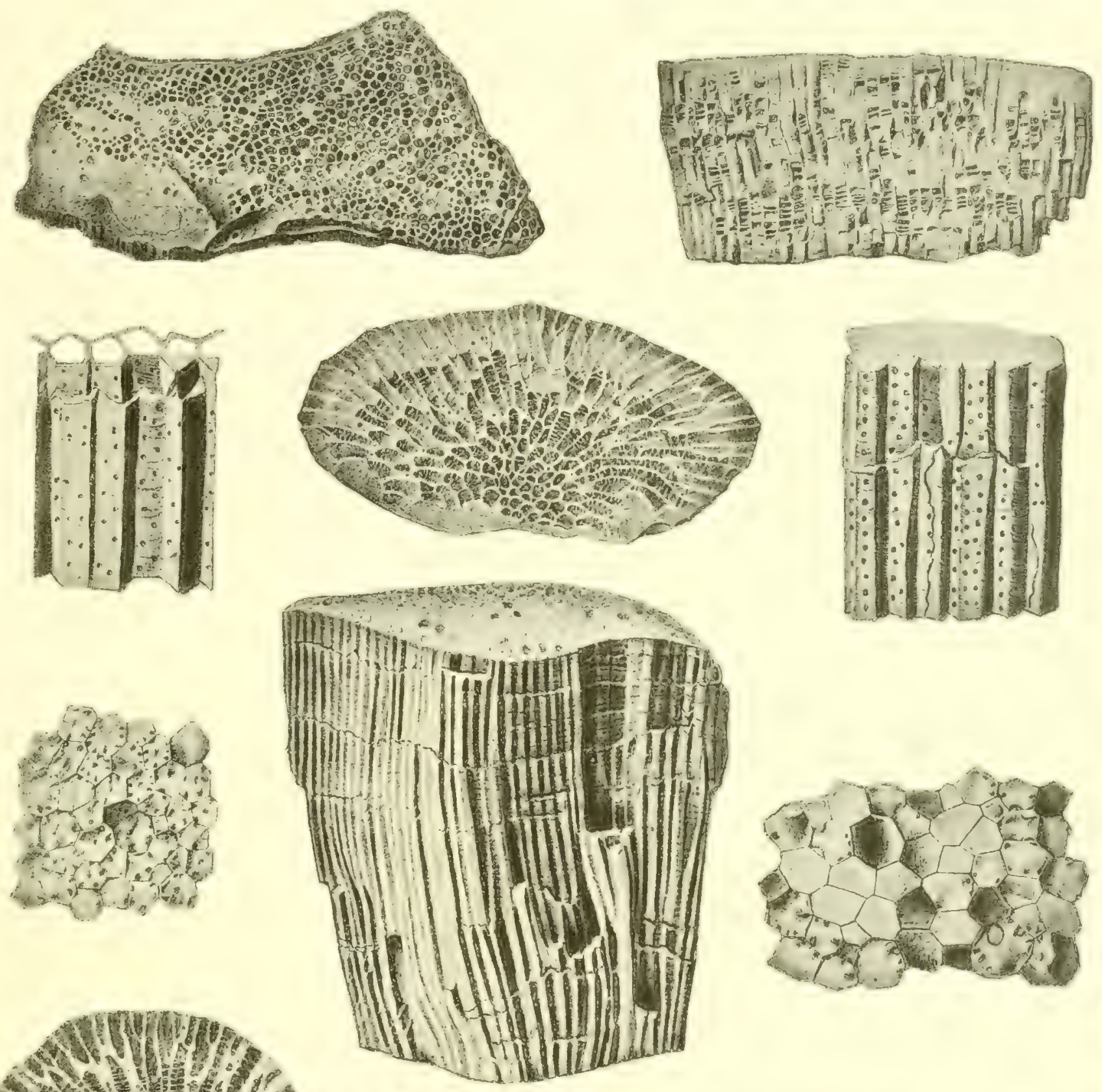

ANIVIVI

10.
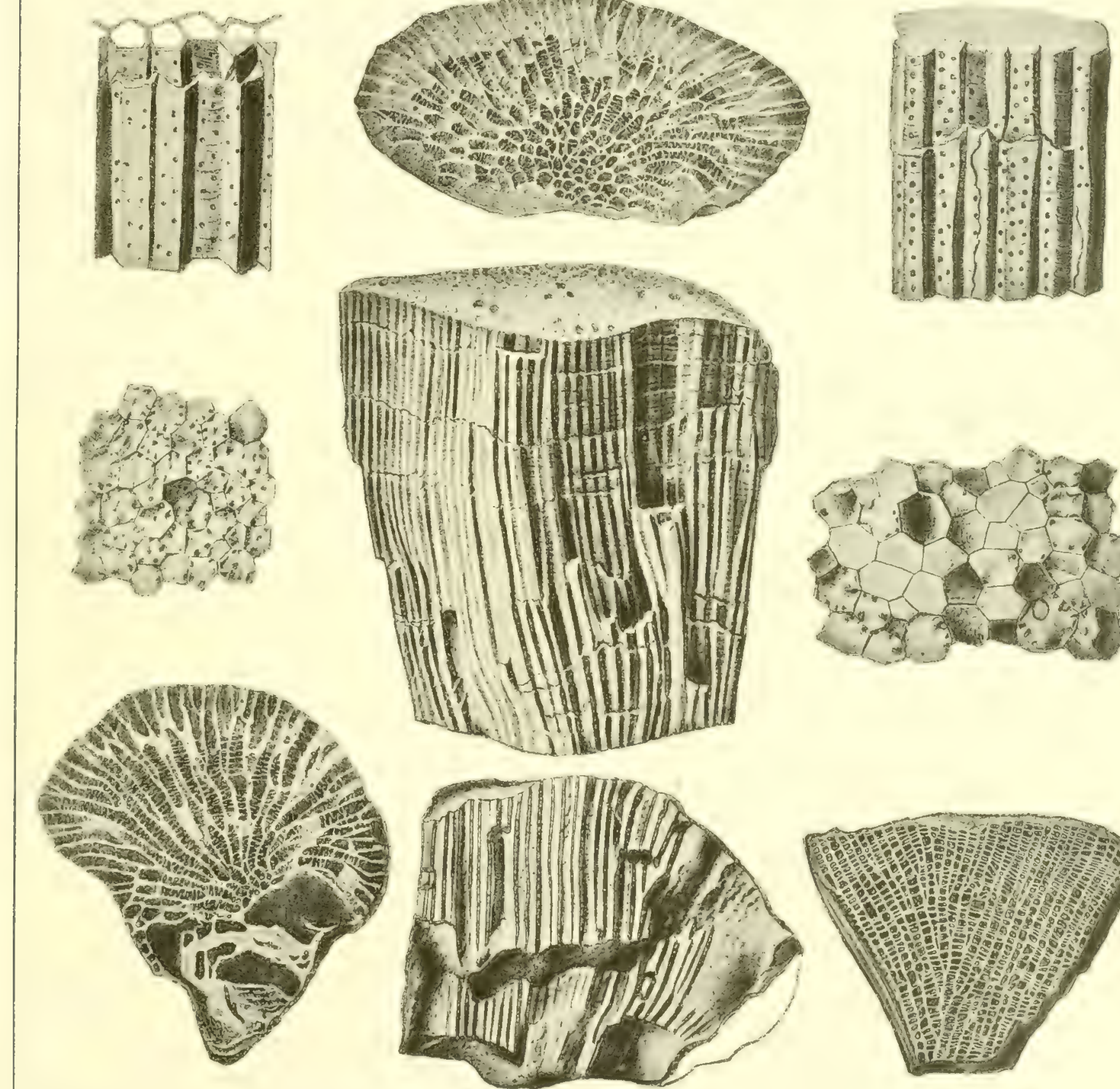



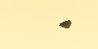




\section{PLATE XXXV.}

Favosites placexta.

Farosites placenta Romiuger. Geological Surrej of Michigan: Palæontology. [Ined.]

Figs. 1 and 2. Lateral and summit views of a young colony having a subturbinate form.

Figs. 3 and 4. Lateral and summit views of an irregularly growing subturbinate form.

Fig. 5. A larger, depressed and more spreading form.

Fig. 6. An extremely expanded form, showing some inequality in the size of the cells.

Fig. 7. A lateral view of the specimen fig. 6, showing the elevation and inequalities of the surface.

Fig. 8. An enlargement of the open cells, from the specimen fig. 6 .

Fig. 9. The cell-apertures, from a polished surface of the specimen fig. 6 .

Fig. 10. An enlargement of the cell-apertures, from the base of the specimen fig. 3 , showing them closed by operculæ.

Fig. 11. A farther enlargement of the cells of fig. 3, showing the operculi.

Fig. 12. An enlargement of a rertical section, from the specimen fig 6 , showing the partial diaplragms and a few large pores. Hamilton group, at numerous localities in Western New York, and at Widder and Bosanquet, Ontario. 


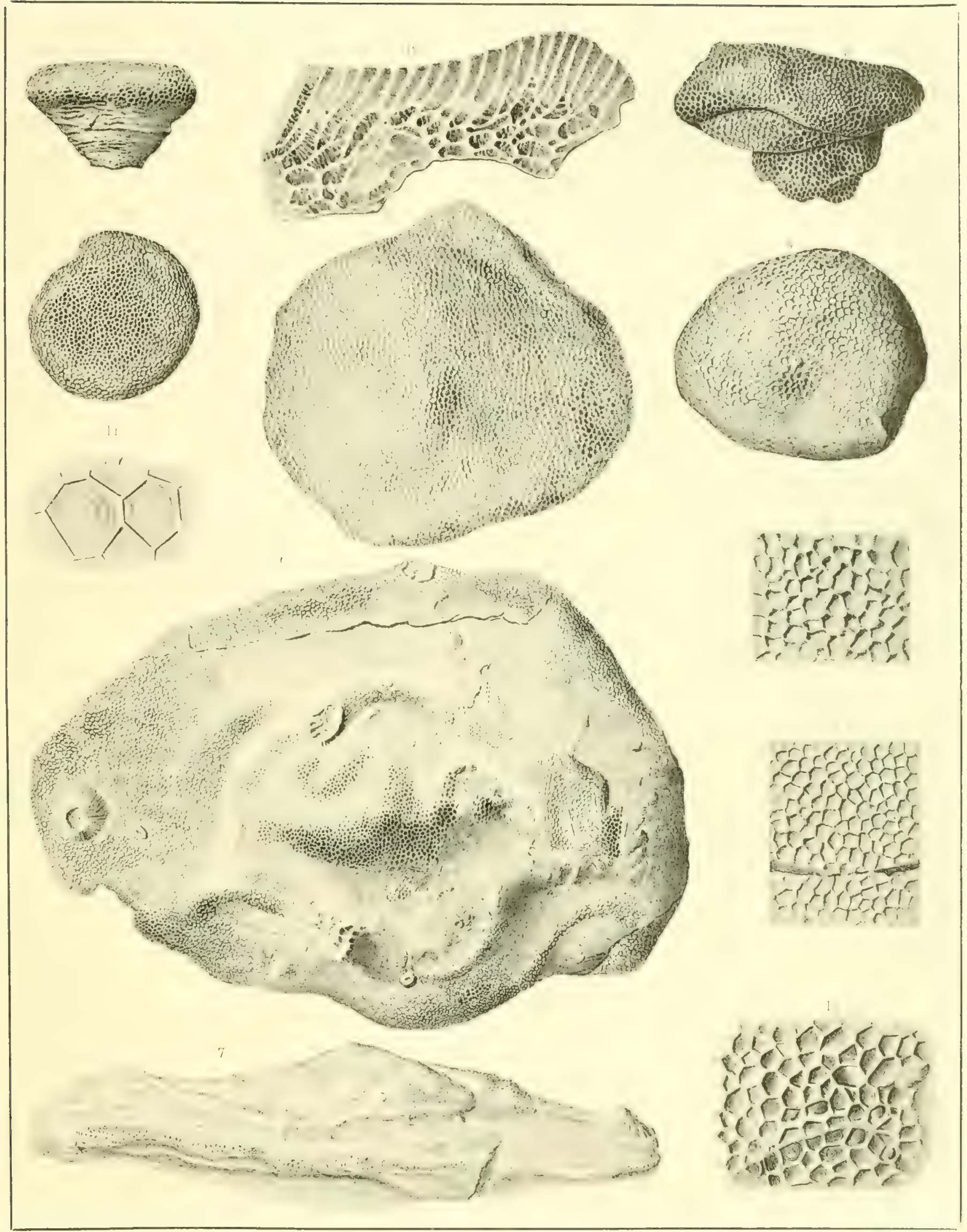



. 


\section{PIATE XXXVI.}

Favosites arbuscula n. $\mathrm{sp}$.

Fire. 1. A fragment of a branching form, with irregular cells,

Fir. 2. An irregular form which has its origin near the center and extending in both directions in a subcylindrical form.

F... 3. An obliquely lateral view of a small colony, growing in a cespitose form.

Fir. 4. A form similar to the preceding, but of more extended growth.

Fir. 5. A large arborescent form. The base has been broken off, so that the full extent is not known.

1... 6. An enlargement from another colony, showing the form and external aspect of the cells.

Fir. 7. A longitudinal section of a branch, showing the cells, with interrupted diaphragms.

Fiw. 8. An enlargement from a longitudinal section of a branch, showing the cells and diaphragms.

Fu. 9. A transwerse section of a branch, showing the cells at their origin in the center. Hamilton group, at Moscow and York, in Livingston county, and other places in Western New York. 


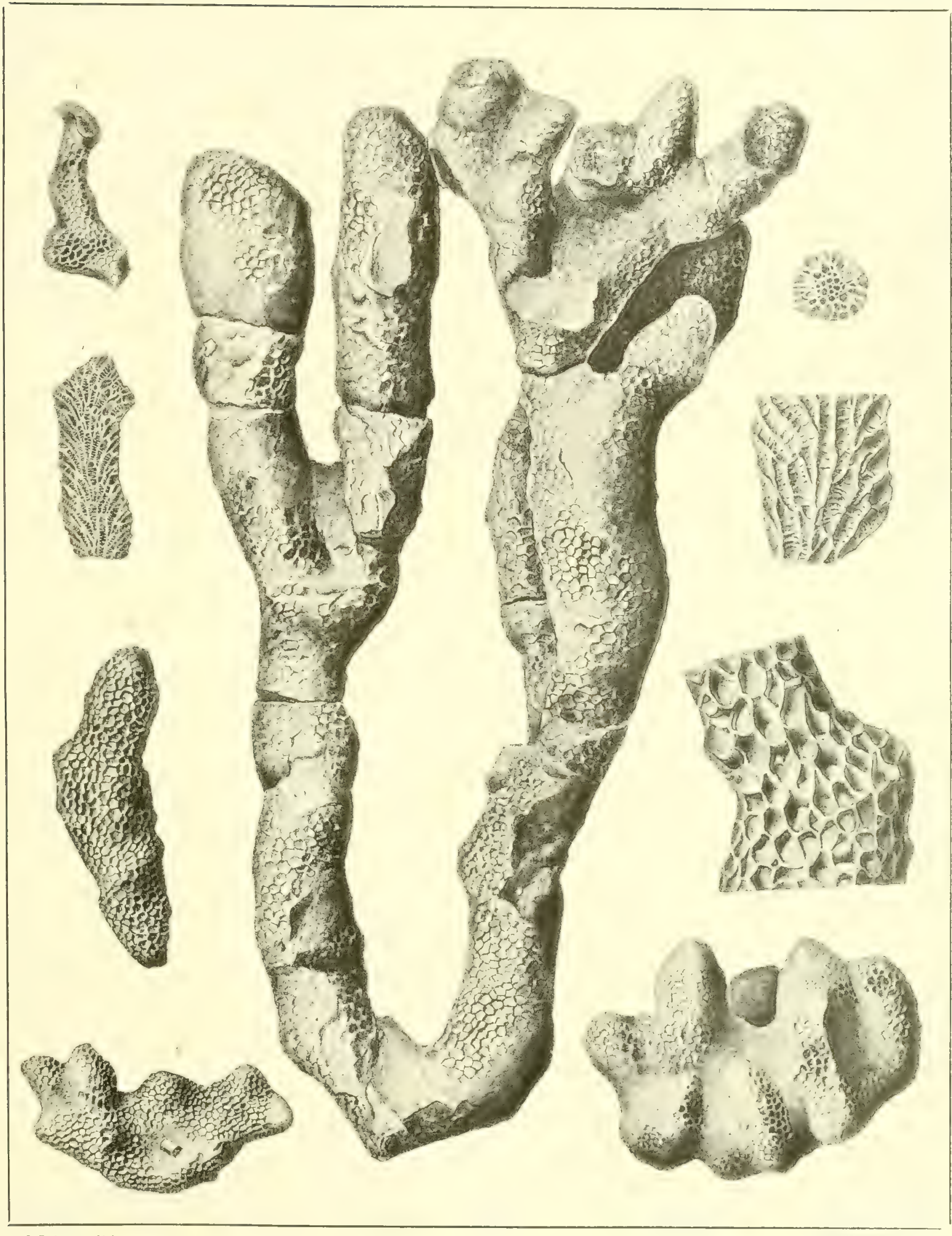





\section{PLA'TE XXXVII.}

\section{Chateites furcatus n. sp.}

Fig. 1. A fragment of a large branching specimen.

Fig. 2. Two fragments from a larger broken specimen imbedded in calcareous shale.

Fig. 3. An enlargement of the cell-apertures as they appear upon the surface of fig. 1.

Firg. 4. An enlargement of the cell-apertures from the specimen fig. 2.

Fig. 5. A longitudinal section from a branch highly magnified, drawn from photographs and accurately representing all that is visible in the section. Hamilton group, Norton's Landing, Cayuga Lake, and other localities in Western New York.

\section{CHateTES TENUIS n. sp.}

Fig. 6. The base of a hemispheric specimen, with a freshly fractured surface, showing the fine columnar structure.

Fis. 7. An enlargement from a polished portion of the upper part of the same, showing the forms of the cells.

Fig. 8. A vertical section, greatly enlarged, showing the cell-walls and distant diaphragms.

Fig. 9. A vertical section of a similar form, where the cell-walls are thicker and the diaphragms more numerous, while at a few points there are markings like mural pores.

Fig. 10. A transverse section enlarged, showing the form and proportions of the cells (drawn from a photograph.) Figs. 9 and 10 are referred with doubt to this species, until farther studies shall determine their positive relations. Upper Helderberg Limestone at Stafford, Genesee county, N. Y.

\section{Chetetes hunilis n. $\mathrm{sp}$.}

Fig. 11. A fragment of a hemispheric form, showing the fibro-columnar structure of the mass.

Fig. 1:. An enlargement of several of the cells or columns, as they appear on the surface of the specimen fig. 11 .

Fiv. 13. An enlargement from a transverse section, to show the form and proportions of the cells.

Fir. 14. A longitudinal section, showing the cell-walls and transverse diaphragms.

Fig. 15. A longitudinal sectior of a fragment of the species, showing the cell-walls and diaphragms (drawn fiom a photograph.) Upper Helderberg Limestone, Western New York.

\section{Chatetes tabulatus n. $\mathrm{sp}$.}

Fig. 16. A vertical section of a subturbinate mass, showing the fibro-columnar structure.

Fig. 17 . An enlargement of several of the columus from the surface of the specimen fig. 16 .

Fig. 18. An enlargenent of a transverse section, showing the form and proportions of the cells.

Fig. 19. A longitudinal section enlarged, showing the undulating vertical cell-walls without visible diaphragms.

This species belongs to the horizon of the Lower Helderberg group, and has been placed in this association through accident. 


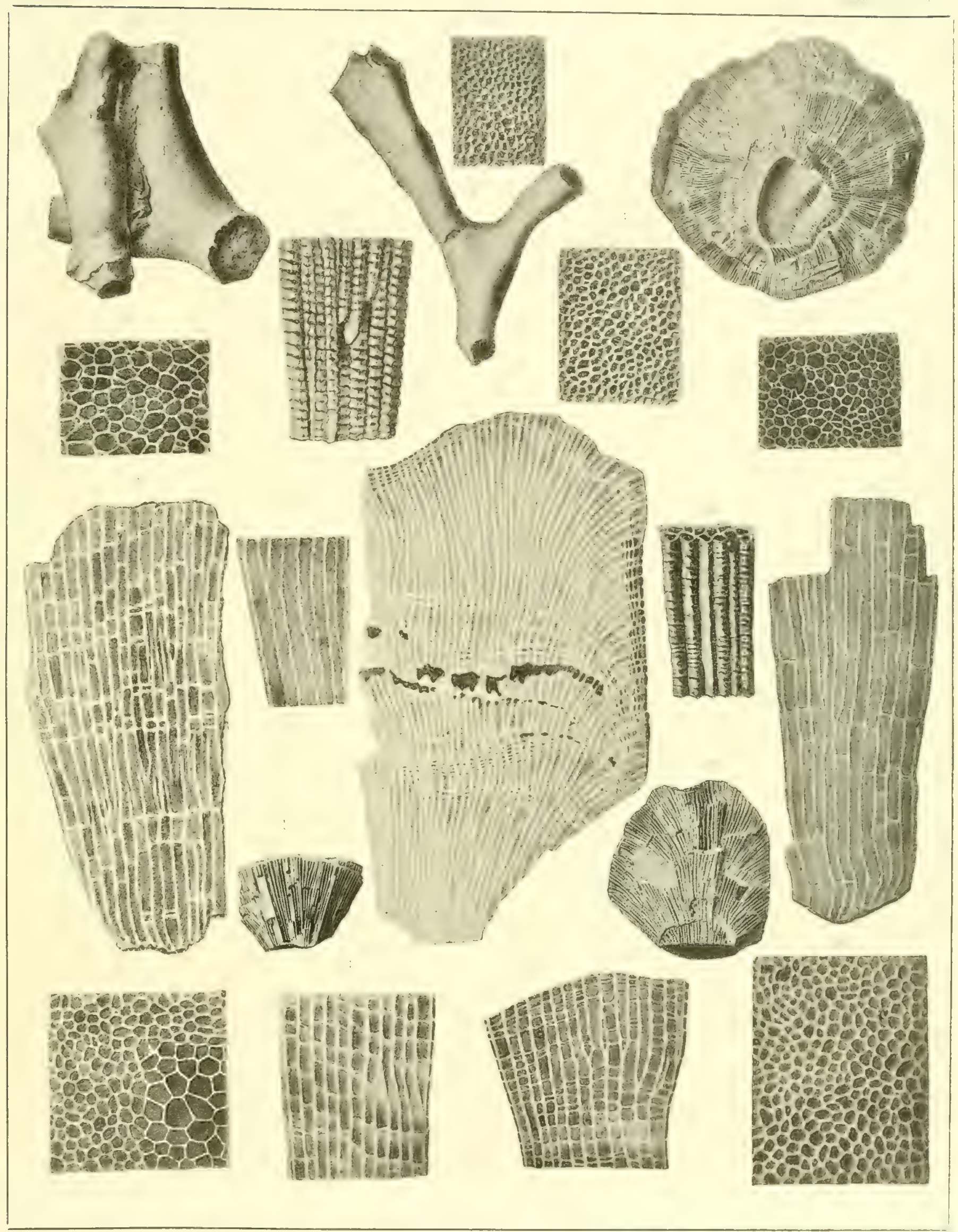




\section{PLATE XXXVIII.}

\section{Chemetes fruticosus n. $\mathrm{sp}$.}

Fig. 1. A strong growing stipe supporting several smaller branches. The surface, with the exception of the upper branches, is maculose.

Fig. 2. A branching form which shows several bifurcations; the bases of the branches only being preserved. The remaining branches are irregularly thickened and larger than the parent stipe below.

Fie. 3. An enlargement of the columns from the broken surface of one of the branches. On several of the cell-walls there are marks like mural pores, which, if proven to be such, will remove the species from this genus to Favosites.

Fig. 4. An enlargement from the surface, showing the cell-apertures with the maculæ marked by larger cells.

Fir. 5. A polished surface, highly enlarged, showing the cell-walls with few diaphragms except. near the outer margins. Hamilton group, shore of Canandaigua Lake and other places in Western New York.

\section{CH ETETES FURCATUS.}

(See also Plate 3\%.)

Fig. 6. A small branching specimen.

Fig. 7. A larger specimen which has had at least six bifurcations in the course of its growth. The lower extremity is partially cicatrised over a broken surface, and the remainder covered by a Bryozoan, a species of Callopora.

Hig. $\checkmark$. A portion of the broken surface at the base of one of the branches, showing the character of the columns enlarged.

Fig. 9. An obliquely longitudinal section of a fragment, showing the cell-walls with few diaphragms, except in places near the outer margin.

This and the preceding form have many characters in common, and may ultimately prove varieties of the same. The maculose surface of the first is, however, a distinctive external feature, while under an ordinary magnifier the fractured surfaces present the differences observable in figs. 3 and 8 of the illustrations. 


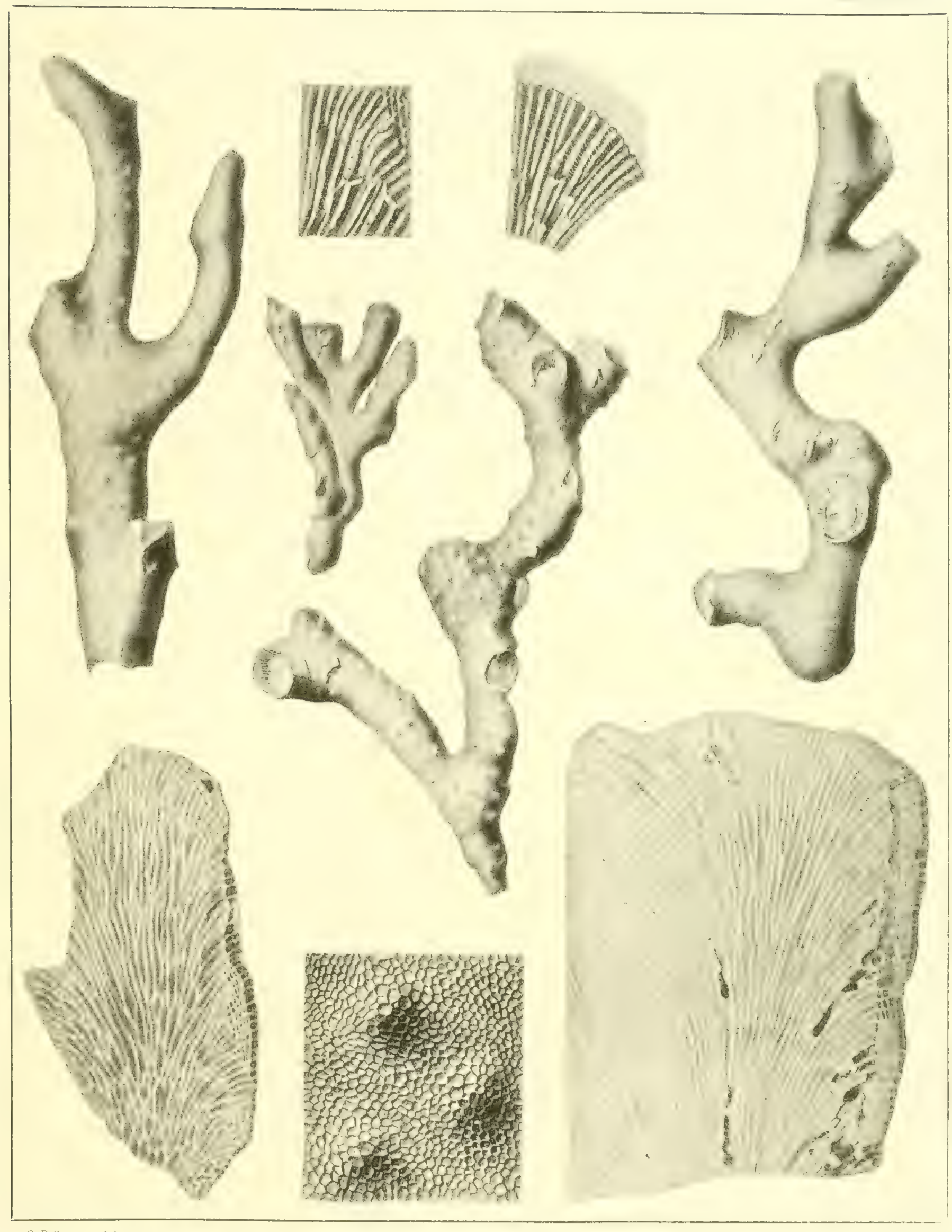





\section{PLATE XXXIX.}

\section{CYATHOPHYLLUM? PERLAMEJLOSUM.}

Compare Aulachophyllum sulcatum Edw.-Haime. Polyp. Foss. Terr. Palroozoiques, p. 355, pl. 6, fig. 2.

Fig. 1. A small specimen, the view looking obliquely into the calyx and showing the deep anterior fosset. There is a slight malformation of the lamellæ on one side.

Fig. 2. The calyx of another specimen, showing the anterior fosset, and one on each side directed obliquely forward. The lamellæ are finer than in the preceding specimen, and it may possibly prove a distinct species.

Fig. 3. A lateral view of an imperfect specimen.

Fig. 4. The calyx of the preceding specimen, showing the deep anterior fosset.

Fig. 5. An external anterior view of a well-preserred specimen, which is partially denuded of the epitheca.

Fig. 6. Another riew of the preceding specimen, showing the interior of the calyx, with the distinct narrow fosset.

The specimens bear much resemblance to Aulachophyllum sulcatum Edwards \& Haime, but the lamelle are more numerous, and the cellulose exterior portion of the coral shows its generic aftinities with Cyathophyllum or Heliophyllum.

\section{CYATHOPHYLUUM VALIDEM n. Sp.}

Fig. 7. An anterior view of a large specimen, showing the primary lamellæ, with the lateral secondary ones diverging therefrom.

Fig. 8. A lateral view of the preceding specimen, showing the lateral primary and secondary lamellie.

Fig. 9. A view looking directly into the calyx. This beautiful robust form occurs in the Upprr Helderberg Limestone, near Batavia, and other places in Western New York: Ontari ), and at the Falls of the Ohio.

\section{Amplexts Yandelit.}

Amplexus yandelli Edw.-Haime. Polyp. Foss. Terr. Palæozoiques, p. 314, pl. 3, figs. 2, 2a.

Fig. 10. A figure of a somervhat distorted specimen, which is imperfect at the base. The lamellæ. of the calyx are somewhat more slender ard extend more nearly to the center than represented in the figures cited above. 


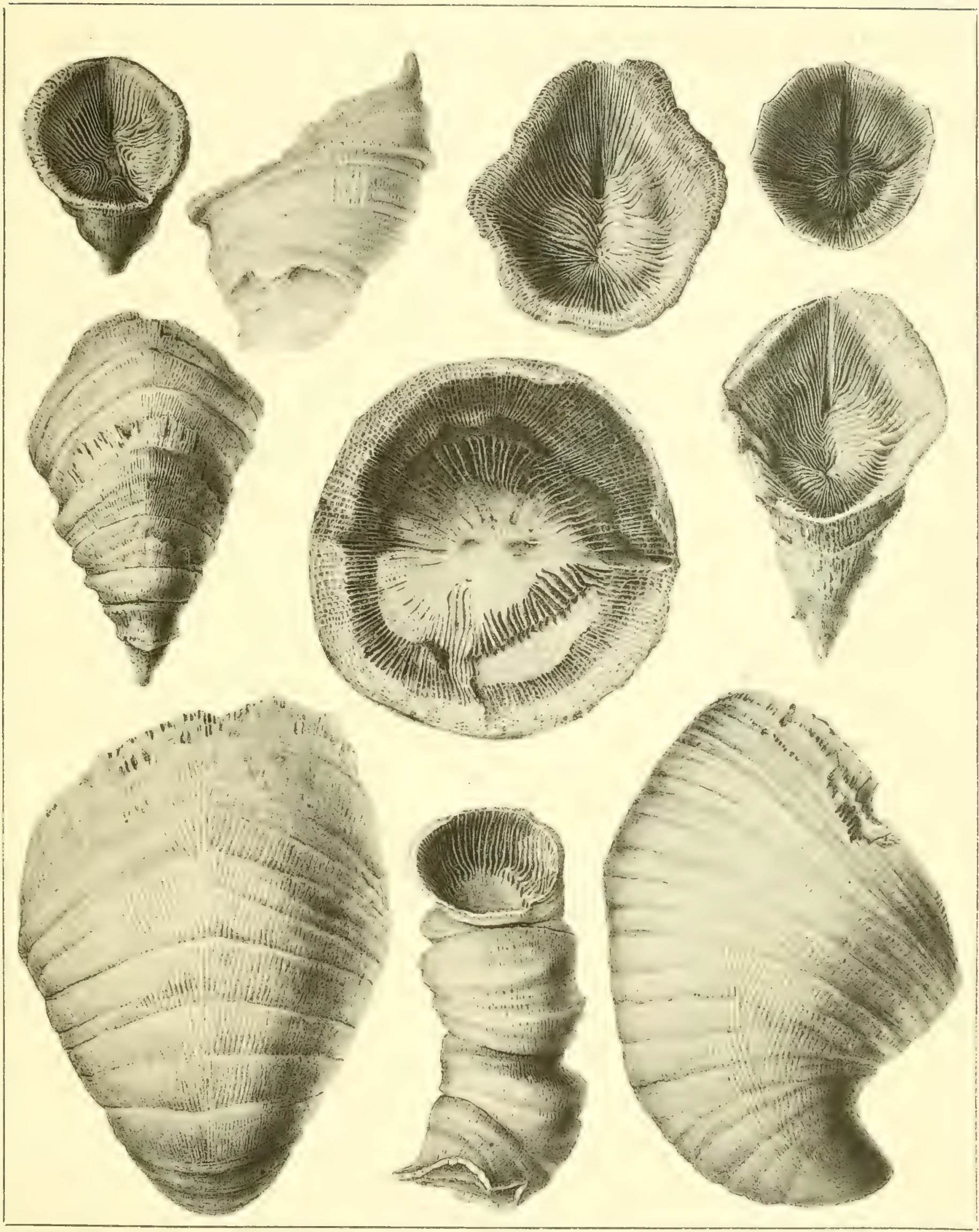


.

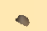






